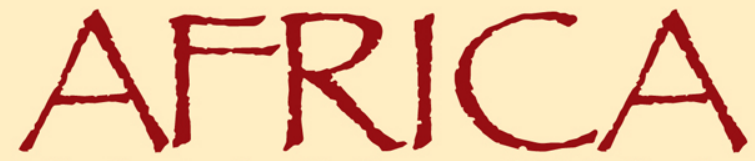

Adjusting to the Challenges of Globalization

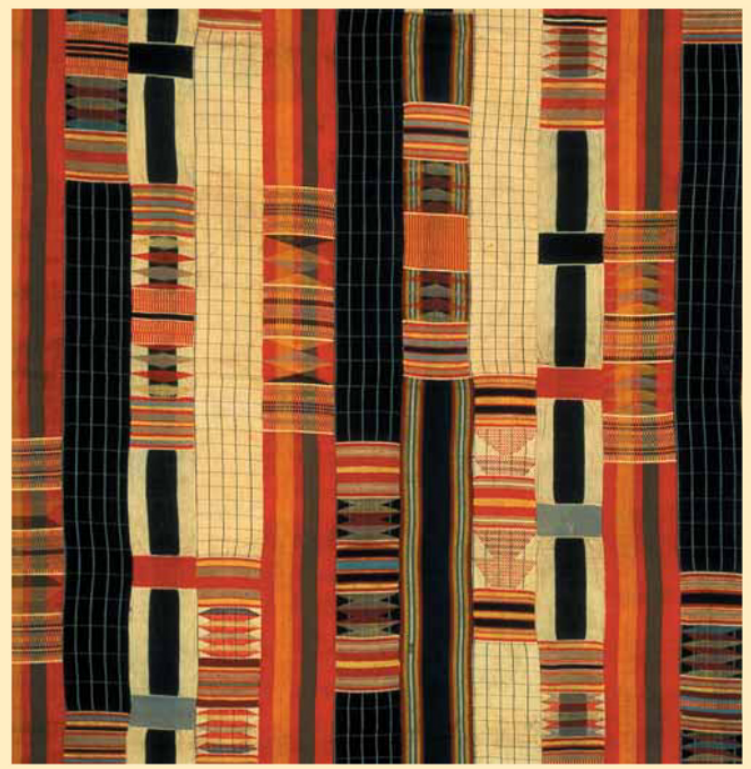

Editor

LAURA WALLACE

International Monetary Fund $•$ Ministry of Finance of Japan 


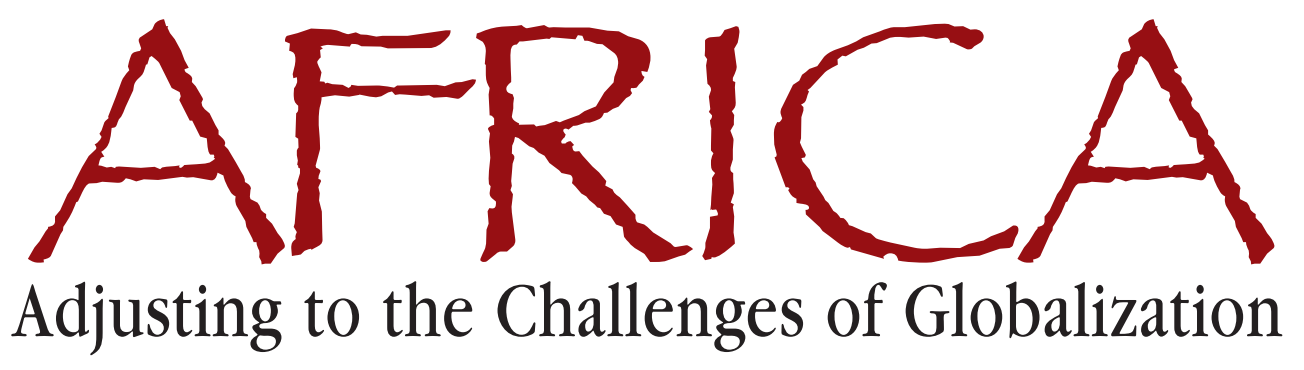

\section{Adjusting to the Challenges of Globalization}

\section{Editor \\ LAURA WALLACE}

International Monetary Fund $\bullet$ Ministry of Finance of Japan

CInternational Monetary Fund. Not for Redistribution 
(C) 1999 International Monetary Fund

Production: IMF Graphics Section

Cover design and figures: Luisa Menjivar-Macdonald

Typesetting: Alicia Etchebarne-Bourdin

Cover image: Strip Cloth, Asante peoples, Ghana,

cotton, silk, H x W: $158 \times 97.8 \mathrm{~cm}\left(62^{3 / 16} \times 38^{1 / 2}\right.$ in),

National Museum of African Art, National Museum of Natural History, purchased with funds provided by the Smithsonian Collections

Acquisition Program, 1983-85, Lamb EJ10598,

Photograph by Franko Khoury

\section{Library of Congress Cataloging-in-Publication Data}

Africa: adjusting to the challenges of globalization/editor, Laura Wallace.

p. $\quad \mathrm{cm}$.

"Proceedings of a seminar held in Paris, May 4-5, 1998."

Includes bibliographical references.

ISBN 1-55775-829-8

1. Free trade-Africa-Congresses. 2. Structural adjustment (Economic policy)—Africa-Congresses. 3. Investments, ForeignAfrica-Congresses. 4. Africa-Economic policy-Congresses. I. Wallace, Laura.

HF2416.A37 1999

$338.96-\mathrm{dc} 21$

99-058965

Price: US\$23.50

Address orders and inquiries to:

International Monetary Fund, Publication Services 700 19th Street, N.W., Washington, D.C. 20431, U.S.A. Telephone: (202) 623-7430; Telefax: (202) 623-7201

E-mail: publications@imf.org Internet: http://www.imf.org 


\section{Contents}

Preface

$\underline{\text { vii }}$

Acknowledgments

$\underline{x i}$

Abbreviations

$\underline{\text { xii }}$

Overview

Laura Wallace

$\underline{1}$

I. IMPROVING THE ENVIRONMENT FOR PRIVATE INVESTMENT AND ACTIVITIES

1. Opening Remarks

Motomichi Ikawa

$\underline{15}$

2. Lessons on Regulatory Reform: The Philippines' Experience Florian Alburo

3. Lessons on Regulatory Reform: Kenya's Experience

Harris Mule

Comments

Vina-Seeburn Dabeesingh

$\begin{array}{ll}\text { Iain T. Christie } & 38\end{array}$

General Discussion $\quad \underline{43}$

4. Developing Sound Banking Systems and Practices in Africa Piero Ugolini

5. Relevance of Banking Lessons for Africa: Zimbabwe's Experience Leonard Tsumba 


\section{Comments}

James Cross

Hiroyuki Hino

General Discussion

6. Liberalizing the Trade System

Robert Sharer

\section{Comments}

Hirohisa Kohama

Ibrahima Makanguilé

General Discussion

$\underline{100}$

II. StRengthening THE CONTRIBUtion OF GOVERNMENT

7. Better Public Sector Resource Management: Capacity

Building and Good Governance

Emmanuel Tumusiime Mutebile

Comments

Kwesi Botchwey

John Roberts

Reinold van Til

General Discussion

8. Quality and Composition of Public Spending in Africa:

Suggestions for Increased Effectiveness

Luca Barbone

\section{Comments}

Gray Mgonja

Emmanuel Tumusiime Mutebile

Takuma Hatano

Jan Willem Gunning

Sanjeev Gupta

General Discussion 


\section{REFORM PRIORITIES FOR AFRICA}

\section{Panel Discussion}

Tomáz Salomão

Koichi Hamada

Jesus Estanislao

Anupam Basu

Micah Cheserem

General Discussion

\section{Concluding Remarks}

Evangelos Calamitsis

The following symbols have been used throughout this book:

... to indicate that data are not available;

- to indicate that the figure is zero or less than half the final digit shown, or that the item does not exist;

- between years or months (e.g., 1998-99 or January-June) to indicate the years or months covered, including the beginning and ending years or months;

/ between years (e.g., 1998/99) to indicate a crop or fiscal (financial) year.

"Billion" means a thousand million.

Minor discrepancies between constituent figures and totals are due to rounding.

The term "country," as used in this book, does not in all cases refer to a territorial entity that is a state as understood by international law and practice; the term also covers some territorial entities that are not states, but for which statistical data are maintained and provided internationally on a separate and independent basis. 
This page intentionally left blank

CInternational Monetary Fund. Not for Redistribution 


\section{Preface}

n May 4-5, 1998, senior officials and private sector agents from more than 20 African and Asian countries, and staff from the IMF, the World Bank, and other multilateral institutions, met in Paris for a seminar on Adjusting to the Challenges of Globalization in Africa. It was the fourth in a series that began in 1994, intended to provide a forum for exchanging views on economic policies and financing strategies that could deepen the structural reform process in Africa. This seminar-sponsored by the Japanese Ministry of Finance and organized jointly with the IMF-was also meant to serve as a stepping stone between the recently completed external evaluation of the IMF's Enhanced Structural Adjustment Facility, its concessional loan facility for low-income countries, and the second Tokyo International Conference on African Development in October 1998.

The seminar was held at a time when Africa's economic performance and outlook were improving. After two decades of lost opportunities, real GDP was, on average, growing at 4-5 percent-for the most part thanks to sound economic policies-and per capita incomes were on the rise; gains that sub-Saharan Africa has managed largely to hold on to. Yet, Africa needs much faster growth if it is to make up for lost ground and make a real impact on poverty reduction. The seminar was thus cast around finding ways to sustain and accelerate Africa's growth in a globalized world economy.

The seminar focused on two topics. First was improving the environment for private investment and activity, and taking better advantage of the benefits of globalization, with sessions held on approaches to fostering a good regulatory environment, developing sound banking systems and practices, and liberalizing the trade system. Second was strengthening the contribution of government, especially in the areas of capacity building, good governance, effective public resource management, and improving the quality and composition of government spending. These topics were viewed 
against the backdrop of what lessons Africa could learn from East Asia-both from its decades of remarkable growth and development, and from its 1997-98 financial crisis.

In the papers and discussions, several broad themes emerged. First, we should be careful not to overreact to the recent Asian financial crisis and, in the process, throw out the good with the bad. Asia's remarkable growth had been brought about, in large part, by its open and flexible markets; so the answer was to move ahead with liberalization efforts, but to do so in a way that careful attention is paid to sequencing and needed safeguards.

Even so, there was reason to rethink the overall growth strategy, given today's increasingly globalized environment. Even in May 1998-an early stage of reflections on the lessons of the Asian financial crisis - it was apparent that a central element of the answer likely laid in a new focus on transparency and accountability, or what is commonly called good governance. This would involve redefining the roles and responsibilities of the public sector and government, the private sector, and international institutions. For countries, that means creating modern administrations with competent civil servants, which, in turn, calls for capacity building - an area where the multilateral institutions and bilateral donors can be of much help. Programs and technical assistance should be more demand-driven, however, with country ownership of reforms a must.

Second, we need better communication both within African countries and between African countries and the rest of the world. This means engaging all stakeholders in a constructive domestic dialogue on reform, thereby encouraging country ownership, and hence giving reform greater credibility and inviting a positive response in private sector activity. It also means bridging the "image gap" between the old and emerging Africa. As several African participants pointed out, many of their countries had made great progress in recent years, and yet outside investors were hesitant to respond. While the onus was on Africa to tell the world of its successes, bilateral donors and multilateral institutions could do more to spread the word.

Third, we need to take a more holistic approach toward economic, financial, and social reforms. This means moving away from an individual project approach to a sectoral approach, couched within medium-term expenditure frameworks. Indeed, this is already beginning to happen, with its many challenges-such as establishing good practice guidelines for donor coordination and assistance to help achieve better policy coherence. 
The IMF, for its part, has taken numerous steps in recent years, reflecting lessons learned in seminars such as this one and the many internal and external evaluations that have been undertaken on our programs and policies. The emphasis has been on helping countries establish sound financial systems and institutions, transparency, ownership-embracing the various segments of civil society-and more effective social policies in order to promote poverty reduction. In keeping with this spirit of greater openness, we have steadily opened up and broadened our own dialogue with member countries.

Building on these steps, at the September 1999 Annual Meetings of the IMF and World Bank, the two institutions agreed to put country-led poverty reduction strategies at the heart of their lending programs for the world's poorer countries. This is part of a coherent strategy to help poor countries move on to a sustainable faster growth path, bringing a substantial reduction in poverty-a strategy that will need to include sound macroeconomic policies. The new Poverty Reduction and Growth Facility, which replaces ESAF, is founded on this strategy and is designed to ensure consistency between the country's macroeconomic, structural, and social policies in a mutually reinforcing fashion. We look forward to working with the entire development community, with renewed vigor, on making the new millennium one that is characterized by prosperity, peace, and stability for all.

JACK BOORMAN

Director

Policy Development and

Review Department

International Monetary Fund 
This page intentionally left blank

CInternational Monetary Fund. Not for Redistribution 


\section{Acknowledgments}

\footnotetext{
$\boldsymbol{T}$ he seminar was organized by Hirofumi Suzuki of the Interna1 tional Finance Bureau of the Ministry of Finance of Japan; Daiho Fujii of the Office of the Executive Director for Japan in the International Monetary Fund; and Louis Dicks-Mireaux, Elliott Harris, and Il Houng Lee of the IMF. Help with the logistical arrangements in Washington, DC, was provided by Cecilia Lon and, in Paris, by Ghislaine Roche and Christine Ursenbach of the IMF's Paris Office. I would like to thank Helen Chin of the IMF's External Relations Department for her skillful style editing and for preparing the volume for publication.
} 


\section{Abbreviations}

$\begin{array}{ll}\text { APEC } & \text { Asia-Pacific Economic Cooperation } \\ \text { EC } & \text { European Community } \\ \text { ESAF } & \text { Enhanced Structural Adjustment Facility } \\ \text { G-7 } & \text { Group of Seven } \\ \text { HIPC } & \text { Heavily Indebted Poor Countries } \\ \text { IDA } & \text { International Development Association } \\ \text { MTEF } & \text { medium-term expenditure framework } \\ \text { OECD } & \text { Organization for Economic Cooperation and } \\ & \quad \text { Development }\end{array}$




\title{
Overview
}

\author{
Laura Wallace
}

\begin{abstract}
A s Africa attempts to better integrate itself into our increasingly Aglobalized world economy, East Asia's remarkable growth and prosperity over the last few decades provides inspiration. For that reason, African and Asian officials and academics—along with representatives from the IMF, World Bank, and other multilateral institutionsmet in Paris on May 4-5, 1998, to exchange experiences.

But as Co-Chairman Motomichi Ikawa asked in his welcoming remarks, in light of the recent financial crisis in East Asia, was it still possible for Africa to draw lessons from Asia? He said the answer was yes, because countries can learn from both successes and failures. He cautioned, however, that it would be wrong to conclude that some of the basic policies behind Asia's past high economic growth-primarily, an active government role in the area of industry and finance-were misdirected. Rather, an active government role was indispensable for creating an environment conducive to private capital flows. And for Africa, it is now essential to promote private investment. Ikawa called on the seminar participants to find a common modality to help Africa realize its potential in the coming century.
\end{abstract}

\section{Session I. Improving the Environment for Private Investment and Activities}

The first session opened with Asian and African perspectives on how best to foster a good regulatory environment.

\section{Fostering a Good Regulatory Environment}

Florian Alburo of the Philippines suggested a key problem was that, in a regime of open economies, differing regulations among 
trading partners tended to reduce trade volume, compared with a situation where regulatory environments were consistent. He said the Asia-Pacific Economic Cooperation (APEC) group has shown the virtues of focusing more on informal barriers to entry and trade than on the formal ones, and then taking steps to ensure that reform programs are consistent with one another. An example would be in the adoption and alignment of product standards to conform with international standards. This theme of the beneficial role of regional arrangements would be heard repeatedly throughout the seminar, especially in the areas of regulatory reform, trade liberalization, and good governance. Benefits mentioned were larger common markets, a more even playing field to help eliminate distortions in resource allocation, and-just as important-a public commitment and peer pressure to help sustain reform. All together, these added up to a more stable and secure environment for investors.

Florian Alburo also underscored the need for eliminating corruption. Certainly, a more transparent regulatory environment would help. He cautioned, however, that corruption is a by-product of many things: asymmetrical information access, weak legal frameworks, and cultural characteristics. For that reason the APEC region was trying to tackle corruption by promoting an infrastructure facilitation network, with the goal of ensuring that information became a public good.

Harris Mule of Kenya raised a disturbing point in his paper: despite the serious implementation of economic reforms since 1993-including steps to make the regulatory framework marketfriendly-Kenya's economic performance had not rebounded. Was this surprising? He thought not, because economic performance was determined by many factors. He suggested that while economic reforms and the underpinning regulatory framework were vital, they were by no means sufficient for the resumption of sustained growth. What could explain the seeming discrepancy between reform and performance? Mule suggested five hypotheses:

- economic agents require confidence that the laws and regulations are stable, predictable, and uniformly applied;

- regulations need to be clear, and there must be incentives for administrative agents to enforce them;

- administration of laws and regulations must be transparent;

- time-phasing and sequencing of policy must be carefully thought out; and 
- institutional capacity, especially in the civil service, must be built up.

Nonetheless, Vina-Seeburn Dabeesingh of Mauritius insisted that Kenya's reform efforts were not misdirected. Kenya was in a state of transition and it took time to create conditions for the market to work effectively. What could Africa do to attract investors? She suggested better infrastructure, legal and regulatory reforms, and institutional reforms. It was the efficiency of implementing policy decisions that would determine the attractiveness of the country to investors at large and, consequently, the rhythm of industrialization. She also called upon policymakers to get the word out on reform efforts to foreigners and the local populace-the latter to build a consensus for reform.

Iain Christie of the World Bank stressed the importance of a policy dialogue with all stakeholders. Time and again it has been proven in Africa that "stroke of the pen" reform does not work. Indeed, this need to include the various segments of civil society in the ownership of reforms was one of the main themes of the seminar, echoing a sentiment that is increasingly felt in donor and recipient circles. Christie also urged policymakers to look at privatization in a broader context than the transaction itself, to include market structure and the policy environment. In telecommunications, for example, it was much more important to introduce competition than to simply privatize the national carrier.

In the general discussion that followed, many African participants expressed concern that their countries had undertaken difficult reforms, yielding results, yet foreign investors were still slow to respond. Mansour Cama of Senegal, speaking for the private sector, suggested that the problem was, in part, Africa's image to the rest of the world-what Co-Chairman Motomichi Ikawa later called "the image gap." Cama suggested that Africa, along with its partners, should do a lot more to project a positive image for investors.

Participants agreed that other needed items were political stability, macroeconomic stability, good infrastructure, institutional capacity, regional integration, and a sound financial sector. Iain Christie of the World Bank also suggested that the risk associated with investing in Africa was much overplayed in the media. He said rates of return in Africa were very attractive and investors just needed to manage risk by diversifying their portfolios. 


\section{Developing Sound Banking Systems and Practices}

The seminar focused on financial reform, looking at priorities in banking sector reform, key operational lessons, and "new lessons" from Asia.

Piero Ugolini of the IMF stressed the need for Africa to accelerate structural reforms, especially in this area, if it hoped to attract large volumes of capital investment. Critical elements would include an independent and accountable central bank with autonomy in conducting monetary policy to maintain price stability; a sound banking structure; an appropriate banking supervision framework, based on best international standards; and a well-functioning payments system. Also, responsibility for bank licensing and supervision should rest in an independent authority, free of political interference. He said the international community could help by providing technical assistance and training-areas where the IMF was considering how best to intensify its assistance in Africa.

For Leonard Tsumba of Zimbabwe, the emphasis was on ensuring that financial sector reforms were undertaken in an environment conducive to both domestic and foreign investment, otherwise, they would be meaningless. This means adopting transparent, consistent, and predictable procedures and policies-along with subscribing to international standards. He said prospects of an economic boom in Africa were immense. But given Africa's limited financial resources and shallow export capacity, aggressive market-oriented policies would have to be the order of the day.

James Cross of South Africa concurred with both speakers, choosing to elaborate on a few points. Financial market specialists and regulators seemed to agree more and more on the importance of a stable macroeconomic environment as a prerequisite for sound banking, yet this message was not being fully conveyed to the public at large. Yes, Africa had few well-trained nationals, but ironically, competition from abroad might well be needed to strengthen human capital and raise service levels and professionalism in the domestic banking sector. A key reason why South African banksunlike banks in other countries-were not having problems funding credit was because their holdings of government debt had been whittled down to only 7 percent of their assets. And on exchange rates, the central bank had found that the key to pacifying the markets was transparency. 
Hiroyuki Hino of Japan provided an Asian perspective and suggested that the "new lessons" from the Asian crisis were really just an application of the "old lessons" of the Asian miracle to the management of banking systems in an era of globalized financial markets. These included the need for effective government, strong banking institutions, and flexibility in exchange rate management. He urged Africa not to overreact to the Asian crisis by reversing or unnecessarily slowing financial liberalization. After all, Asia's tremendous economic growth over the last three decades was, in large part, thanks to the capital inflows that had come about in a liberal policy framework.

In the general discussion that followed, many African participants cited the need to bring down interest rates and to deepen financial intermediation. Mansour Cama of Senegal suggested that West Africa's main challenge now was in devising ways to mobilize savings and investment through effective financial intermediation. Jan Willem Gunning of the University of Oxford, however, asked if solving the problem of intermediation would really bring about high investment rates in Africa? He submitted that the answer was no. The binding constraint was not a lack of credit, but rather a wariness on the part of private entrepreneurs to invest, in part because of policy credibility problems. Financial sector reform was, thus, important but not a magical solution.

\section{Liberalization of the Trade System}

Turning to trade liberalization, Robert Sharer of the IMF noted that, although much progress had been made in recent years, Africa had started from a highly restrictive position. As a result, most African trade regimes remained significantly more restrictive than those of other developing regions. Thus, the issue was not whether trade regimes should be liberalized but rather how fast and how deeply.

As for lessons from East Asia, he said the main one should be that trade reforms-combined with other structural reforms and a strongly supportive macroeconomic climate-contributed to the region's impressive economic growth and export performances over the past few decades. But he also highlighted another lesson from the recent financial crisis: only lowering tariffs and nontariff barriers can mask a high degree of administrative discretion, hence the need for transparency and good governance. 
Hirohisa Kohama of Japan added a note of caution and controversy, suggesting that over the medium and long term, Africa's growth potential was lower than Asia's, even with policy reforms. He also suggested that political stability and investor confidence in the region were more critical for Africa than rates of returns, if Africa hoped to attract more foreign direct investment. Africa should seize the opportunity — as Japan had done in the late 1950s and 1960s-and prepare itself for future competition with foreign companies by encouraging fierce competition among domestic companies.

Ibrahima Makanguilé of Mali, speaking for the private sector, added a different note of caution, asking whether Africa should really make trade reform a high priority? Mali's trade relations were among the most liberal, yet the well-being of its people had not kept pace with economic progress. He also felt that trade and business should be liberalized under the aegis of a strong state, but in most African countries, administrations were weak, inefficient, and corrupt. Even so, trade liberalization in West Africa was now unavoidable, and for that reason, policymakers should focus on human and physical capacity building; the private sector should better organize itself for lobbying; and the bilateral and multilateral institutions should be sure to include civil society in the search for solutions to development problems.

In the general discussion that followed, several speakers again suggested that Africa had an image problem, so much so that it was a major impediment to foreign investment. Tomáz Salomão of Mozambique conceded that political stability was vital, but so was a new world attitude. Kwesi Botchwey of Ghana quoted studies showing that businesspeople around the world had a high level of ignorance about Africa's progress in the 1990s. Compounding matters was a "neighborhood effect" that hurt small countries doing the right things but that were geographically situated next to large countries in trouble.

A few participants wondered if trade reform was really that important for Africa at this point in time. Jan Willem Gunning of the University of Oxford countered the skeptics by making a strong case for trade reform. He said studies showed that trade restrictions in Africa were actually more damaging than when countries elsewhere adopted the same restrictions - the reason being that so many African economies were quite small. 


\section{Session II: Strengthening the Contribution of Government}

In the second session, the seminar examined capacity building and good governance, with perspectives from donors, multilateral institutions, and recipients.

\section{Better Public Sector Resource Management}

Emmanuel Tumusiime Mutebile of Uganda, in his paper, told the story of Uganda's 1994 Capacity Building Plan, which predated the World Bank-supported Partnership for Capacity Building in Africa, launched in 1996. The plan was formulated after several years of consultations with all the major stakeholders, and was founded on three precepts: sound economic management, private-sector capacity building, and civil service reform. A milestone in the restoration of good governance and the rule of law came in 1995 with the promulgation of a new constitution. Uganda now tries to monitor progress through national integrity workshops and national integrity surveys, the results of which are published. Citizens are asked which governmental departments and districts are the most corrupt, and which services are likely to entail a bribe.

Kwesi Botchwey commended Uganda's capacity building program as being comprehensive, with the right focus and all the right objectives. But he said there were many operational pitfalls, as Ghana well knew, because it had pioneered some of the initiatives. At root was a problem of lack of ownership, which in turn gave rise to other problems, such as undue reliance on foreign consultants and programs that were project driven. The solution was to repose some trust in the governments to determine their own capacity building needs.

John Roberts of the European Commission gave the donor perspective, depicting good governance as a hierarchy of building blocks, in ascending order of staff, systems, ethos, and leadership. External partners could help develop the capacities of individual staff and advance into institutional capacity building. But they often lost their way in a fog of alternative agendas if the ethos of the host country counterparts were in question. Indeed, development cooperation worked best when the host country showed a strong spirit of public service and strong leadership.

Reinold van Til of the IMF asked if it was possible to reform the civil service from within, or was it necessary to move certain func- 
tions outside the core civil service and entrust them to quasiautonomous bodies. He felt it was noteworthy that when certain functions had been removed from the civil service, the efficiency of government had improved. But when those same functions were left within the established structure of government ministries, even after reorganizations and reforms, they tended not to be well executed.

In the brief general discussion that followed, several speakers agreed with van Til's comment on civil service reform. Godfrey Simasiku said Zambia's revenue authority and export board became more efficient once they were made independent. Gray Mgonja of Tanzania noted that removing certain functions from the civil service, in effect, redefined the role of government. Jan Cedergren of Sweden seconded Botchwey's observation that capacity-building programs tended to run into trouble because of lack of ownership. Indeed, this was a central message of the 1998 external evaluations of the IMF's Enhanced Structural Adjustment Facility (ESAF) and the World Bank's Special Program of Assistance for Africa.

\section{Quality and Composition of Public Spending}

The seminar then looked at ways to improve the quality and composition of public spending. Luca Barbone of the World Bank observed that, so far, project assistance from donors had proven simply to be a Band-Aid approach; and because the patient was constantly changing positions, the Band-Aid eventually came off. For there to be consistent delivery of services, there needs to be both a stable flow of resources and sound management. How could a stable resource flow be assured? That requires a commitment on the part of the government-and the more depoliticized the budget allocation process can be, the better.

How could sound management be assured? That involves policymakers and donors thinking in terms of desired outcomes over the medium and longer term. In other words, donors need to replace the project enclave mentality with an approach that emphasizes institution building, predictability of resources, and accountability by public officials. To do this, Barbone said the emphasis must change from individual projects to medium-term expenditure frameworks (MTEFs).

Mgonja commented on Tanzania's experience with trying to mobilize resources and deploy them effectively. One avenue was through fiscal discipline, given the importance of maintaining macroeconomic stability. Here, he noted, the debt burden was tak- 
ing away a sizable amount of government resources. Another avenue was through switching to a program approach from the project approach. Tanzania was preparing an MTEF, with the request for such a framework originating with the government, and the priority sectors already designated by the government. The next step was to discuss the proposal with all of the stakeholders, including donors, as the government took greater ownership.

Mutebile commented on Uganda's experience with MTEFs, which were adopted to improve long-term expenditure planning. The main shortcoming was its exclusion of donor-funded projects, which in most African countries comprised the largest share of the development budget. He also worried that African governments lacked the capacity to make detailed assessments of the effectiveness of expenditures - insufficient manpower compounded by poor data. Moreover, he suggested that the World Bank's and IMF's detailed conditionalities for structural adjustment loans could be counterproductive to long-term institution building because they removed the responsibility for taking politically difficult decisions.

Takuma Hatano of the Export-Import Bank of Japan focused on how governments could help attract private investment, noting that they stood to play a decisive role in private infrastructure investment. He called on governments to ensure public investment was efficient, provide a sound regulatory framework, and pursue macroeconomic stability - a key lesson of the recent Asian financial crisis.

Gunning welcomed Barbone's advocacy of monitoring the outputs rather than inputs of a project - a positive step towards performance-based lending. But on Barbone's suggestions for monitoring, he worried that the methods would only find the symptoms of the disease but not address the fundamental problem; the main reason behind Africa's poor public service provision was not simply insufficient spending. On the importance of ownership, he concurred with Barbone, pointing out that this was a key finding of the 1998 external ESAF evaluation. He disagreed, though, that donors should be "honest brokers between political players to maintain the MTEF agreement," as he worried that this would fundamentally undermine ownership.

Sanjeev Gupta of the IMF elaborated on Barbone's mention of the need to improve the composition of public expenditure, especially in outlays for health and education. Was this process under way in Africa? Yes, but substantially more needed to be done. Recent data-weak as they were-showed that social expenditures were 
biased against primary education and primary health care over the 1980s, and this trend continued in the 1990s. What could be done? Some possibilities included a better intrasectoral allocation to benefit the poor; shifts in geographical targeting to benefit the poor; stronger civil service reform; devolution of spending to the lower levels of government; and a bigger role for the private sector.

In the general discussion that ensued, many participants-both on the donor and recipient side-underscored Barbone's message of the need to move away from the individual project mentality. Peter Freeman of the United Kingdom Department of International Development suggested that aid was already changing from a separate series of project inputs to a program of financial support directly related to the budget and sectoral priorities.

Several participants also observed, however, that with this change in emphasis would come new challenges. Roberts mentioned that donors were unsure what criteria should be applied, especially toward judging intrasectoral efficiency. Gunning suggested that donor countries be more selective, just financing those governments that met the donor country's criteria, but doing so on the basis of a broad assessment, not detailed micromanagement, and doing it over the long term instead of quarterly monitoring.

\section{Session III. Reform Priorities for Africa}

The final session began with a panel discussion on reform priorities for Africa. Tomáz Salomão of Mozambique argued that liberalizing the economy while adopting an outward-looking policy orientation was not enough. Three other steps-often overlooked-were needed: knowing when liberalization required new and different regulations; ensuring that the benefits of globalization were broadly shared; and undertaking tough institutional reforms. On the last step, gains were likely to be slow. It was easy to change the law but hard to change habits and ways of doing business, although in the end it could be done. The country that did it the best would reap the rewards.

Koichi Hamada argued that the IMF's ESAF should pay more attention to intertemporal choice-viewing the balance of payments as a dynamic, forward-looking concept. In Asia and Africa during the past few decades, both continents had been running current account deficits. But whereas in Asia both savings and investments 
had been high (of course, until the recent financial crisis), in Africa both savings and investment had been low. The key difference was that in Asia high investment had generated economic growth, which was vital because only with an increase in long-term growth could countries afford to pay off their debt.

Jesus Estanislao of the Philippines stressed three lessons from the Asian crisis: (1) the importance of strong macroeconomic fundamentals (including keeping exchange rates at realistic levels); (2) the importance of a strong banking system (ensuring that the central bank has enough autonomy to avoid the crony capitalism evident in East Asia today); and (3) the importance of a strong commitment to reforms. On the last point, it was critical to strike precisely in a period of crisis, and to build up civil society. "While we take care of economics and finance," he said, "we cannot disregard the politics, the social aspects, and indeed the broader aspects of society."

For Anupam Basu of the IMF, the critical issue was the need to pinpoint a set of reform priorities - not the need to establish a hierarchy among them. This was because the reforms being discussed (i.e., regulatory, financial sector, role of government, and trade) were complementary and mutually reinforcing. At this stage, Africa needed market-oriented policies, aimed at both promoting private sector development and accelerating Africa's integration into the global economy.

Micah Cheserem of Kenya, in his written remarks, singled out two top-priority areas for Africa. The first was the need to educate all stakeholders, as economic reforms also affected ordinary citizens, and not just the elite who controlled information. This effort should be done by African countries in collaboration with the IMF and World Bank. The second was the need to more aggressively implement economic and political reforms. After all, for economic reforms to be successful, they must be accompanied by political reforms-including a multiparty democracy, good governance, a free press, and respect for human rights. For this reason, he felt it was opportune for the IMF to become actively involved in political reforms.

In the final discussion, participants focused on reform priorities, with the most common theme being the need for better communication-especially of Africa's successes. This included exchanges between the public and private sectors, within these sectors, between African policymakers and civil society, and between Africa 
and the rest of the world. As Cama put it, the world needed to know that African governments had undertaken reforms, and that the reforms were working. He also echoed Basu's message about the need for a set of reform priorities, rather than a hierarchy among them, because, in the end, everything would become a priority given all the interlinkages.

\section{Concluding Remarks}

In the concluding remarks, Co-Chairman Evangelos Calamitsis noted that even though Africa's development partners have a vital role to play in supporting reform programs, everyone agreed that efforts to develop effective institutions and regulations-and to remove any remaining official tolerance for corruption-must be homegrown. This was consistent with one of the central findings of the IMF's 1998 external ESAF evaluation.

Moreover, where there is successful reform, the countries and donors alike need to do a better job of conveying the message to foreign investors. "In other words, we must help bridge the "image gap' between the old and emerging Africa." 
This page intentionally left blank

CInternational Monetary Fund. Not for Redistribution 


\title{
1
}

\section{Opening Remarks}

\author{
Motomichi Ikawa
}

I

$\mathrm{t}$ is a great pleasure for me to welcome all of you to the Seminar on Adjusting to the Challenges of Globalization in Africa, organized jointly by the Government of Japan and the IMF. I am delighted to see many familiar faces and new participants from Africa, Asia, North America, and Europe. May I also take this opportunity to express our appreciation to the three external evaluators of the IMF's Enhanced Structural Adjustment Facility, who have kindly accepted our invitation.

This is the fourth in a series of seminars on policies for growth in Africa since 1994. The three previous seminars have sought to draw lessons from the development experiences of East Asian countries and examined how those could best be adapted to Africa's development.

But given the current situation in Asia, we could ask whether it is still possible to draw lessons from Asia. The answer is yes-one can learn from both a success and a failure.

We believe it is quite significant when weighing the most appropriate development strategy for Africa to take into account the results of studies and analyses of East Asia's development experience. But there has been a tendency on the part of casual observers to conclude that some of the basic policies behind Asia's past high economic growth-primarily, an active role of government in the area of industry and finance-were misdirected. We do not share this view. We believe that an active role for government is indispensable for creating an environment conducive to private capital flows. In- 
deed, for there to be sustainable growth and poverty reduction, central and local governments must play appropriate roles.

So then, what lessons can African countries draw from the recent currency crisis in Asia? First, the Asian crisis occurred in countries where relatively sound macroeconomic management, including a tight fiscal policy, had been in place. The direct causes of the crisis-and those contributing to the currency turmoil—include rigid foreign exchange rate systems, excessive foreign short-term borrowing in the private sector, and fragile and poorly supervised financial systems. In this respect, it is now widely recognized that too much reliance on short-term foreign capital without adequate supervision, transparency of data, and deep financial markets can undermine the stability of the economy.

Second, and more important, the crisis has highlighted risks that are common to emerging market countries with open economies that have achieved high economic growth through capital inflows. It is becoming increasingly clear, however, that the dangers stem from poorly sequenced and unbalanced liberalization of capitalnot capital liberalization itself. In this context, policy sequencing is vital. For without sound development of the financial sector prior to liberalization of capital transactions, risk management and monitoring may not work properly.

In the Group of Seven (G-7) process leading up to the Birmingham Summit in May 1998, as in other forums, serious discussions are taking place on the issue of crisis prevention and crisis management. Which areas are being identified for developing countries to focus on? The key ones are enhanced transparency and data dissemination, sound preparations for global capital flows, and stronger national financial systems-all areas that African countries will need to address vigorously if they hope to benefit from globalization by achieving high economic growth through increased trade and investment. In this connection, Japan places particular emphasis on greater transparency, including of the policymaking process within the IMF, and better monitoring of short-term capital flows.

\section{Agenda for Africa}

So where does this leave Africa? The Asian economic crisis has not distracted the attention of the major industrial countries from 
Africa. In the Birmingham Summit, Africa's problems will receive needed critical attention, an outgrowth of the 1997 Denver Summit's call for continued support of the democratic and economic reform efforts by African countries. A G-7 Working Group has reaffirmed the commitment to a partnership with sub-Saharan Africa and endorsed the following orientations in seven areas.

- On mobilizing resources, the group looks forward to a full and speedy implementation of the Debt Initiative for the Heavily Indebted Poor Countries (HIPC) and to replenishments of both the African Development Fund of the African Development Bank and the International Development Association (IDA) of the World Bank. It is encouraging to observe that there is support for a speedy extension of debt relief to more countries and, at the same time, a recognition of the need for an adequate replenishment of soft loans. As there is no guarantee that such a favorable environment will continue for the coming decade, African countries are encouraged to seize these opportunities to lay the groundwork for sustainable growth.

- On financial sector development, the group highlights the need for vigorous efforts to build open, transparent, and robust financial systems, including nonbank financial and micro-finance institutions. In Africa, excessive government intervention in state-run financial institutions is often the cause of the accumulation of nonperforming debts.

- On trade, while urging the international financial institutions to place a greater emphasis on trade reforms in economic programs, the group commits itself to ensuring liberal access to its own markets for African countries. Here, I should note that the emphasis is on avoiding protectionism on both sides, the developing and industrial countries.

- On investment, the group encourages a more innovative use of multilateral and bilateral investment guarantees to improve the investment climate.

- On governance, the group calls for international financial institutions to intensify their efforts in the design and implementation of economic reform programs.

- On capacity building, the group welcomes efforts by African countries to increase the proportion of budgets directed to social expenditures. 
- On regional integration, the group urges international financial institutions to place greater emphasis on regional perspectives, in particular on developing regional assistance strategies. It is well known that national economies in sub-Saharan African countries are small and do not allow for economies of scale. So it is quite significant that a regional focus is becoming a key consideration in a number of domains, such as trade, investment, financial sector development, and modalities of assistance.

While the G-7 Working Group deals with these seven areas, I must admit that some important ones are missing; these include population growth and agricultural development, areas that might be quite interesting if some speakers would touch on them from time to time.

Finally, I would like to mention Japan's financial support of Africa. With regard to multilateral assistance, above all, Japan is the largest donor to the 11th replenishment of IDA, with a total of approximately $\$ 22$ billion contributed over three years beginning in 1997. Japan is also the largest donor to the African Development Fund. On the HIPC Initiative, Japan has taken the lead by contributing approximately $\$ 37$ million to the IMF's ESAF/HIPC Trust Fund in support of these initiatives, following the contribution of $\$ 10$ million to the HIPC Trust Fund in the World Bank. In terms of bilateral assistance, as of 1995, Japan was the second-largest donor to the entire region and was the largest donor to 6 out of 47 African countries.

I would also like to call your attention to the Second Tokyo International Conference on African Development to be held in Japan in October 1998. This conference is organized jointly by Japan, the United Nations, and the Global Coalition for Africa. We hope that many of you will be able to take part in this conference. Just holding this conference is, in my view, a manifestation of Japan's commitment to Africa.

\section{Seminar Topics}

As for our seminar here today, after a few decades of stagnation, per capita incomes in African countries have started to pick up in recent years. To consolidate and spread this trend throughout the African continent, apart from the need to make the most efficient use of overseas development assistance, it is essential to promote 
private investment. With that in mind, we have structured the seminar around three sessions, each of which will afford plenty of opportunities for discussions.

Session I will focus on improving the environment for private investment and activities. Session II will deal with strengthening the contribution of government. And Session III will consider reform priorities for Africa in a globalized world.

I hope that after this two-day seminar, all participants will be able to share a common view that opportunities are ripe for African countries in the coming century, and agree on a common modality to achieve this goal. 


\section{2}

\section{Lessons on Regulatory Reform: The Philippines' Experience}

Florian Alburo

What I would like to do today is discuss what I consider to be Whe preconditions for successful regulatory reform, review some illustrative cases, and touch on some of the potential directions that would improve regulatory reform and the regulatory environment in developing countries.

\section{Preconditions for Reform}

There are a number of macroeconomic preconditions for a good regulatory environment. These include:

- a more open economic stance,

- trade liberalization,

- privatization of state-owned enterprises, and

- deregulation of markets.

It is easy to say, in rhetorical terms, that these are important but, in practical terms, what we have to understand is that each of these four preconditions themselves require preconditions, and that policymakers will have to devise appropriate mixes among them.

Going back to our list of preconditions then, in practical terms, this means that for a movement toward a more open economic 
stance, there must be a critical political constituency. Of course, that is not an easy task, and fortunately for economists and professors, that is not what we do, so I will not dwell on that.

For trade liberalization, it is not just a question of reducing tariffs or liberalizing imports, but also of what should be liberalized first, inputs or outputs? Which industries should be liberalized first, export-oriented or import-oriented? Theoretically, one can always say let us liberalize across-the-board, but that is easier said than done. Also, what should be the timing and sequencing? Should it be the capital account or the current account first? These are issues that are not only germane to academic discussions but also to political economy debates.

For privatization, preconditions include developing local capital markets and the pricing of initial public offerings of state-operated enterprises prior to their sale. For deregulation, preconditions might include ruling out extreme concentration of ownership or extreme concentration in markets, which then raises the issue of associated trade liberalization.

So each of the macroeconomic preconditions have preconditions themselves. That is already a tough agenda. Moreover, each implementation experience should lead to what I call cumulative lessons and more successful reforms. Then, too, the regulatory environment may require complementary discretion on the part of the bureaucracy, either in terms of facilitation or mandates from higher authorities.

\section{Sample Cases}

Let us take a look at what I consider to be three illustrative cases.

The first one involves the Philippines. It illustrates what I consider to be a cumulatively refined foreign investment law. The Philippines first passed a foreign investment law in 1946, and then continuously revised it - the result of cumulative lessons learned-all the way up until 1991 (see Box 1). The first law was targeted at promoting specific industries but by the time the final revision was made in 1991, the Philippines decided, instead, to use a negative foreign investment list. As long as an industry was not on the negative list, foreign investments could be made up to 100 percent. Fortunately, for political reasons, although that list could be used to protect industries, to date, none have been listed. 


\section{Box 1. Cumulatively Refined Foreign Investment Law in the Philippines}

- The 1946 Incentives Act (Republic Act or R.A. 35) provided for preferred allocation of foreign exchange resources while controlling profit remittances. The incentives were for "new and necessary industries," which eventually became importsubstituting industries.

- The 1967 law (R.A. 5186) created the Board of Investments and instituted an investments priorities plan for pioneer and nonpioneer industries.

- The 1970 Export Incentives Act (R.A. 6135) provided separate incentives for nontraditional exports and an exportpriorities plan.

- The 1981 Omnibus Incentives Code (Presidential Decree or P.D. 1789) consolidated all previous incentives laws and harmonized provisions, that were eventually incorporated into a new investment incentives policy.

- The 1987 Omnibus Incentives Code (Executive Order No. 226) further consolidated the incentives administered by other regulatory agencies (export processing zone authorities, tourism development incentives act, agricultural development incentives act).

- The 1991 Foreign Investments Act created a foreign investment negative list allowing for 100 percent equity in areas not on the list, and requiring only a single registration with the Securities and Exchange Commission unless incentives are sought, in which case, registration with the Board of Investments is essential. To date, that list has remained empty.

- The cumulative experience with investment laws finally led to a regulation in 1991 that is characterized by greater transparency and consistency.

In the 1991 law, the Philippines also altered the bureaucratic regulations. Previously, foreign investors had to register with both the Board of Investments and the Securities and Exchange Commission. In 1991 this was simplified so that foreign investors only had to register with the Securities and Exchange Commission and were noti- 
fied that if they wanted investment incentives, they would have to contact another institution-the Board of Investments.

The second case highlights policy choices in trade liberalization and deregulation. Before developing countries embark on trade liberalization and deregulation, many industries and products are typically subject to a range of trade barriers, such as high tariffs, local content rules, quantitative restrictions, and licensing. A commitment to trade liberalization would ideally be neutral, but in practical terms, there are difficult choices to be made.

For example, should final products, intermediate products, or raw materials be liberalized first? What criteria should be used in determining sequencing, revenue generation and value-added, or employment? Which industries should be targeted, export-oriented or domestic-oriented industries?

It is very easy to find examples where these choices are important, and here I would like to cite the case of liberalizing the import of newsprint in the Philippines. Liberalization of newsprint in many countries requires choices because many of the inputs may be subject to restrictions. One problem arises from the fact that caustic soda, in many developing countries, is under some form of quantitative restriction and caustic soda is needed to whiten newsprint. That is why in developing countries, the newspapers are brownish, whereas in developed countries, they are normally white, quite white. Thus it is very difficult for newsprint industries-and downstream industries, such as publishing-to compete if the inputs are subject to restrictions.

Another problem arises from the fact that bunker fuel, in many countries, is also restricted. Bunker fuel is needed to run the machines at integrated pulp and paper factories, which are fuel intensive, and it is these factories that produce newsprint. Instead, the bunker fuel tends to go to certain select oil refinery companies.

Yet another problem stems from the fact that resins tend to fall under some form of quantitative restriction, and these resins are needed for plywood, one of the by-products of an integrated pulp and paper factory. That is why in the Philippines, when the government liberalized the import of newsprint, many of our plywood shipments had to be returned. Why were they returned? Because they warped. Why did they warp? Because they needed a lot of glue. Why did they lack a lot of glue? Because an ingredient of glue is resin, and if resins are very expensive, then manufacturers try to economize on glue. 
Let me now turn to the third case-telecommunications in China. For a long time, foreign investment in China has been heavily restricted, especially in the telecommunications sector, with foreigners forbidden to invest in the operation or management of telecommunication networks. Yet recent regulatory guides for foreign investment in telecoms in China and the legal framework indicate greater liberalization, although as should become clear shortly, this is more an exercise in innovation than anything else.

The creation of Liantong (or Unicom) in 1994, as a cooperative structure of the ministry of railways, the ministry of electronics industry, the ministry of power, and 13 major stockholders, allowed it to offer mobile services, initially in four Chinese cities. This is a fascinating twist, because, in theory, as a corporation of the ministry of railways, Liantong must focus on improving telecommunications in railways, but its mandate has been interpreted to be wider than that. What has happened, then, is that Liantong competes directly with the ministry of post and communications, the dominant state operator, and the third-largest telecom operator, Jitong, which is owned by 26 state institutions.

The way things work is foreign investors conclude their deals directly with Liantong. They also circumvent the foreign investment prohibition by forming equity joint ventures with local firms to construct telecom networks, ostensibly as part of railway improvement-as exemplified by the deal between Liantong and Nippon Telegraph and Telephone International of Japan. Foreign investment returns are in the form of "return for management consultancy and maintenance service contracts."

So, foreign investment modalities used in China include consultancy contracts to run telecom networks and are not considered to be joint ventures, which would require approval by a higher level of government. In addition, because any project exceeding \$30 million in value would require approval at the national level, projects are split up so that they do not exceed the limit. That way, they simply need provincial approval, which goes through Liantong.

These three cases, therefore, show that efforts are being made to be more transparent: in an evolving Philippines foreign investment law; to the extent that countries wish to liberalize and deregulate, policymakers will have difficult choices to make; and finally, that there are innovative ways to circumvent bureaucratic regulations. 


\section{Potential Directions}

So, how is a good regulatory environment fostered, a point that we will keep returning to in our discussions?

Let me suggest one avenue. In a regime of open economies, differing regulations among trading partners tend to reduce trade volume, compared with a situation where regulatory environments are consistent. The example that I want to give here is, of course, APEC. The economies in APEC realize that consistency is an important way to foster a good regulatory environment. Thus, what has happened is that they have focused more on the informal barriers to entry and trade than on the formal ones, and for the informal ones, consolidated reform programs have taken place among all the countries. Let me mention a few of them:

- adoption and alignment of product standards to conform with international standards;

- mutual recognition arrangements, so that qualified individuals can more easily move from one country to another;

- compatible technical infrastructure development, so that support from official development assistance can go toward consistent laboratory and product certification standards; and

- transparency of the remaining regulations.

The APEC countries know that regulatory reforms are vital now, since it is estimated that over the next 10 years, some one trillion dollars will be needed for infrastructure investment in the regionfar higher than what will be available from domestic resources. This means capital inflows will need to be higher, especially in the areas of telecommunications, power, and roads. One way to encourage that is through reforms that range from improving the business climate (e.g., removal of foreign exchange controls, and sale or lease of private lands to foreigners) to improving the financing environment (e.g., liberalization of foreign banking operations, unified stock exchanges, and franchising regulations).

Of course, key to improving the investment climate is eliminating corruption, and it is on this matter that I would like to make my final point. There is a notion out there that corruption is endemic in many developing countries. Indeed, on Transparency International's Corruption Perceptions Index, many Asian and African countries fall way, way below the number that is acceptable. 
Some observers argue that one important result of regulatory reform is the elimination of corruption. But I think we have to be a bit careful here. Certainly, a more transparent regulatory environment reduces corruption. But corruption is a byproduct of many factors: asymmetrical information access, weak legal frameworks, and cultural characteristics. From a development perspective, rapid economic growth amidst an evolving legal and institutional framework invites corruption. From a cultural perspective, personal relations often dictate the manner of economic transactions as they take place in emerging markets.

The APEC region is trying to tackle the corruption issue, in part, by promoting an infrastructure facilitation network. It begins with the assumption that information is not accessible to all interested parties - say, a bidding process for an infrastructure project. Thus, the goal is to ensure that information becomes a public good. The network is also trying to create what is called "good offices"- a coterie of people who know the network in each country. And to the extent that they are the vehicle by which information is generated and made available, that would reduce the costs of doing business in different countries, in the sense that information does not become a basis for the appropriation of rents by select groups or institutions. 


\title{
3
}

\section{Lessons on Regulatory Reform: Kenya's Experience}

Harris Mule

\begin{abstract}
A properly functioning economy requires a set of laws and regulations to govern rights and obligations among the economic agents. The laws cover, among other things, property rights and commercial transactions. In Kenya's case, the law on property-especially land rights-is governed by both statutory and customary law, complex issues that go well beyond the purpose of this presentation. This presentation, therefore, confines itself to laws and regulations that are directly related to issues of economic management. Specifically, it addresses laws and regulations that impinge, positively or negatively, on economic efficiency.
\end{abstract}

\section{The Policy and Regulatory Framework}

Kenya has always enjoyed a relatively open economy. Immediately after independence in 1963, the Kenyan government opted for a mixed economy with a robust private sector. The policy allowed for ownership of property and enterprises by both the state and private sectors. Its laws, enshrined in the constitution, protected individual and corporate property rights, encouraged private enterprise-both domestic and foreign-and advocated Kenya's participation in the world economy via international trade, private foreign investments, and tourism. In addition, the policy advocated 
a strong public sector with government ownership and control of key enterprises, especially in energy, transportation, communications, banking, insurance, and manufacturing.

The government also inherited and expanded a complex set of laws and regulations governing the workings of the economy. The laws were both economywide and sectorwide, but also industry specific.

At the macroeconomic level, exchange rates and interest rates were fixed, determined by the governor of the central bank, in consultation with the minister of finance. The wage rates were determined by the industrial court, within guidelines formulated by the ministers of finance and labor. External and domestic trade were governed by laws and regulations under the authority of the minister of commerce and industry, and so was the establishment or expansion of manufacturing plants. In particular, laws and regulations were in place to govern exports of what were deemed essential commodities, particularly foodstuffs and imports. Similar laws and regulations-including licensing requirements-governed operations in mining, quarrying, transportation, communications, and the rest of the service sector.

There were also extensive laws and regulations covering prices of all manufactured goods with heavy weightings in the low-income price index, services that affected the low-income groups, and virtually all agricultural commodities. In agriculture, this included laws that governed, and still govern, land ownership and use-laws that indirectly affect prices. There were laws, regulations, and procedures that governed producer and consumer prices for agricultural products. There were, and still are, regulations that govern quality and other standards for those commodities. Of all agricultural commodities, only horticulture was not subjected to these regulations.

Beyond prices controls, institutional arrangements were in place to govern procurement, processing, and the movement and marketing of agricultural commodities, including maize, wheat, other cereals, sugar, dairy, meat products, cotton, and pyrethrum (an insecticide) - the latter two being marketed by state or quasi-state monopolies. There were also regulatory authorities created to monitor and supervise production, procurement, processing, and marketing of dairy products, pyrethrum, sisal, tea, and coffee.

This regulatory framework, inherited at independence, was expanded after 1963. New state corporations were created to promote activities in manufacturing, commerce, and tourism. Labor laws 
were amended to establish an umbrella trade union organization. And state- or quasi-state-owned corporations were created to implement the import-substituting industrialization policy that was in place then.

Moreover, the 1973-74 oil crisis - and the pressures it created in the balance of payments and domestic prices-gave rise to even more controls. Quantitative restrictions were imposed against specified commodities, especially those that competed with local manufactures. Parastatals, especially in the manufacturing sector, were awarded more protection, including monopoly or quasi-monopoly status. Control over exchange rates and interest rates was intensified, and the coverage of items under the price control regimes was expanded. Yet in spite of - or perhaps because of-these controls, pressures on the balance of payments, general price levels, and the budget intensified following the second oil shock in 1979. It was at this stage that the government accepted that reform was clearly in order.

\section{Story of Reform Efforts}

Kenya's reform efforts began with partial decontrols on several fronts, supported by a Stand-By Arrangement with the IMF in 1979 and two Structural Adjustment Programs with the World Bank in 1979 and 1982. Foreign exchange regulations remained in place, but exchange rate management was made more flexible with regular adjustments based on a currency basket of Kenya's main trading partners. Similarly, the management of interest rates was made more flexible, with the aim of making deposit rates positive relative to inflation. Some quantitative restrictions were abolished, and in general, import restrictions were relaxed, with greater reliance placed on tariff protection-which was also made uniform. Less sensitive commodities were removed from the price control lists, and the Banking Act was amended to streamline registration policy and procedures for licensing new banks and for strengthening bank supervision.

The story of Kenya's adjustment efforts has been told in many reports and articles sponsored by the World Bank, the IMF, and others. The bottom line is that the adjustment performance was not impressive. The laws and regulations governing the price regime remained intact. The control framework also remained in place, although there was some relaxation, both in terms of intensity and coverage, of the controls. 
By 1992 and 1993, Kenya was experiencing severe external imbalances and budget deficit crises. The chief culprits were political uncertainties caused by political reforms and the withholding of balance of payments support. In response to the crises, and with prodding from the IMF and the World Bank, the government undertook far-reaching economic reforms in 1993. Most of the reforms that had either been withheld or only partially implemented in the 1980s were now fully adopted.

- All domestic factors and product prices were decontrolled.

- Quantitative restrictions on imports were dismantled.

- Import tariffs were rationalized and lowered.

- Exchange controls, including controls on the capital account, were abolished.

- Interest rates were liberalized to reflect market conditions in the money market.

- Laws and regulations confirming monopoly status to state enterprises were repealed (notable among these was liberalization of the marketing of grains).

- Laws to curb monopoly practices were strengthened.

- Measures to privatize nonstrategic state enterprises were set in motion.

Thanks to the serious implementation of economic reforms since 1993, the regulatory framework in Kenya has become marketfriendly. But interestingly, this has not been matched by a rebound in economic performance, as Table 1 shows. Indeed, economic per-

Table 1. Kenya: Regulatory Reform Is a Necessary but Not Sufficient Condition for Growth

\begin{tabular}{lc}
\hline Period & $\begin{array}{c}\text { Average Annual Percent } \\
\text { Change in Real GDP }\end{array}$ \\
\hline $1963-73$ & 6.0 \\
$1976-80$ & 5.5 \\
$1980-86$ & 3.2 \\
$1986-90$ & 5.0 \\
$1991-95$ & 2.2 \\
1996 & 4.0 \\
1997 (estimated) & 2.0 \\
1998 (projected) & 1.0 \\
\hline
\end{tabular}

Source: Government of Kenya, 1997. 
formance has been the worst in the last four decades, and one could even say that there has been a negative correlation between the two. Is this surprising? Not really, because economic performance is determined by many factors, of which the regulatory framework is only one. I would like to suggest that while economic reforms and the regulatory framework underpinning them are vital, they are, by no means, sufficient for the resumption of sustained economic growth.

\section{What Happened to Growth?}

This presentation is not intended to investigate and determine causal linkages between the regulatory framework and economic performance. That exercise is well beyond the scope of this presentation. Instead, I would like to suggest five hypotheses that could explain the discrepancy between economic liberalization and performance.

- Economic agents require confidence that the laws and regulations are stable, predictable, and uniformly applied. Kenya's policy and regulatory environment was not stable in the 1980s. There were many reversals of policy during that decade, and the policies and the regulations underpinning them were not rigorously applied. It can be hypothesized that economic agents were not confident that the far-reaching changes instituted in 1993 would stay the course.

- Regulations need to be clear, and there must be incentives for administrative agents to enforce them. In many cases, the regulations governing the operations of state corporations, especially in the grain and dairy sectors, were unclear and not completely overhauled. Furthermore, the incentive structure for enforcement favored the existing state of affairs. As a result, new regulations were only partially and tentatively applied, and subject to revision.

- The administration of laws and regulations must be transparent. This is particularly so when it comes to administering import tariffs. Before the government streamlined the administration of tariffs, with the creation of the Kenya Revenue Authority, there was widespread evasion of customs duties, with deleterious consequences both to government revenue and the domestic manufacturing sector. 
- The time-phasing and sequencing of policy must be carefully thought out. If not, it can undermine the efficiency of regulations. One example was a mismatch in liberalizing fertilizer and maize prices in 1994. What happened was that the prices of fertilizer were decontrolled, while the prices of maize were left unchanged. This led to fertilizer prices rising, while maize prices remained low. As a result, the viability of maize production was undermined, leading to a drastic drop in production levels.

- Above all else, capacity must be built up. The civil service, in general, and the regulatory agencies, in particular, did not have the needed capacity and incentives to apply the new regulatory regime effectively. Moreover, institutional arrangements to take over the deregulated activities were either weak or nonexistent. This was especially so when it came to privatizing marketing enterprises in the context of a weak private sector.

\section{Conclusion}

The evidence shows that regulatory reforms in Kenya have not been matched by corresponding improvements in economic performance. If anything, the evidence points to the contrary. But this should not be surprising given that economic performance is a result of many factors, of which the regulatory framework is only one. Regulatory reforms must be viewed in the context of the overall incentive structure for economic policies, institutional arrangements, and the country's overall capacity. Moreover, the reforms must be properly time-sequenced and they must be fully owned by the important stakeholders in the economy. 


\section{Comments}

\section{Vina-Seeburn Dabeesingh}

Many African countries have embarked on broad-based reforms to attract foreign investment, but investors are not responding. What is the problem? Harris Mule illustrates an exceptional case where an array of economic and regulatory reforms initiated in the 1990s have not triggered the expected growth in Kenya. It puts into perspective a country where the rate of growth is falling, implying that the level of investment in the economy is also falling.

I do not believe, however, that Kenya's reform efforts are misdirected. Kenya is in a state of transition and there is a time lag to shift from an economic regime where everything has been controlled to a new regime based on market forces. Indeed, there is conclusive evidence that the market works, but it takes time to create the conditions for the market to work effectively.

What is important is that Kenya is getting its economic fundamentals right and making the country market friendly. I believe that if the reforms are maintained, it will be much easier for Kenya to integrate into the regional and world markets-and to attract foreign investment-thus enjoying an edge over other counties that have not initiated reforms.

Thus, from the Kenyan experience, we can say that macroeconomic stability prior to reform is essential and that economic and regulatory reforms are not, by themselves, sufficient for growth; policymakers must also strengthen institutional developments. As Florian Alburo pointed out, it is essential to abolish bureaucratic barriers prior to letting in foreign direct investment, as the Philippines did.

So what barriers need to be abolished? This is what I will focus on in my comments today. In particular, what other measures or strategies should be pursued by African countries wishing to attract investment? And what lessons can we draw from Africa? 
To address these questions it is useful to ask why investors are not coming to Africa. With the exception of very few countries, investors have the impression that:

- Africa's infrastructure-human, physical, and financial-is generally less developed than that of other regions, including a lack of efficient banking and financial institutions;

- there are higher risks of investing in Africa than elsewhererisks due to the political and economic environments and risks associated with the quality of the legal and regulatory framework intended to support private initiatives; and

- Africa's overall institutional framework is weak, undercutting even well drafted laws and regulations.

Let me address these three concerns, individually.

\section{Better Infrastructure}

So what can Africa do to attract investors? Based on the experience of Mauritius - which embarked on gradual liberalization policies in the mid-1980s - a critical prerequisite of foreign direct investment is the existence of an efficient public sector and a prosperous private sector that can ensure growth and development. Investors look for countries where growth is positive and where companies are profitable. Obviously, poor economic performance deters investment. Investors tend to follow growth, not to lead it.

To entice investors, the government and the private sector should delimit their respective roles to minimize competition for scarce resources, giving priority to the private sector. The government should initiate actions for the building up of institutions in support of greater resource mobilization for the private sector. The creation of stock exchanges and leasing facilities will greatly enhance the industrialization process. The government should also establish a framework for a partnership with the private sector, giving the various players (such as industry) the opportunity to express their views on the policy thrust. National policy and decision making should be a matter of shared responsibility and trust.

If the government follows this route, it will enjoy the support of a wide spectrum of the population, and there will be a national consensus on the development strategy to be pursued. No economic reform is successful if there is no consensus-that is, if 
the general population that has to be a party to the reform objectives feels it has nothing to gain, it will not show any interest.

The government actually has an essential role to play in the development of the private sector. It should not only act as a facilitator and catalyst in the process of economic development but also provide the logistical and financial support in the form of infrastructure, training, tax and other incentives; and, of course, ensure political stability, efficiency, and credibility of its institutions, leaving the private sector to invest in the economy and to create employment opportunities.

The government should disengage itself from areas where it cannot produce the best results. It should consider privatizing state concerns-without, however, creating other forms of monopolies-limiting its intervention only to areas that are of strategic importance, and leaving resources to the private sector.

Working with the private sector, the government should identify new growth sectors that are compatible with the expectations of the investors. It can consider setting up industrial zones and provide support to domestic small-scale industry. Government also has an extremely important public relations role to play-developing market access through international relations and friendly ties with all trading blocs, and, of course, increasing markets through base regional groupings.

The image of seriousness and credibility that the government projects to the outside world is critical in attracting investment. Foreign investors will invest in a country not because the private sector advertises that opportunities exist, but because the government clearly demonstrates that such opportunities exist and commits itself to private sector participation.

This means getting the word out to the world on what is being done in the country, and also, getting the word out to the people to obtain their consensus and support. Of course, if the public sector is to be efficient, governmental rules and procedures must be adapted as lessons are learned.

\section{Legal and Regulatory Reform}

Let me now turn to my second point, creating an appropriate legal and regulatory framework. Investors feel that there is excessive use of legislation to regulate business activity. What worries them most is the low degree of certainty and predictability about 
how existing laws and rules are applied. Investors also feel that there is often a great disparity between what the law says and how it is implemented in day-to-day practice. Moreover, some new laws that have been enacted to support investment conflict in substance with other applicable laws.

In some countries, liberalization has been accompanied by decree, but not followed by appropriate legislative steps, creating an atmosphere of uncertainty for investors. Investors believe that there are too many impediments to identifying and exploiting opportunities because of the lack of information facilities, and they believe that they have to go through long and winding procedures-involving several entities within the government that may have different perceptions and concurrent approval power-to get a project approved. Not surprisingly, this puts them off altogether.

Indeed, in the absence of an adequate framework with clear transparent legislation, various interpretations of the law become possible, leaving investors with the impression that the possibility of obtaining authorization to invest or to benefit from incentives announced by the government depends largely on the discretion of certain officials. In other words, that some sort of extra effort may be necessary to get a project through.

Thus, it is vital that the government establish an efficient, credible legal framework with clear and transparent legislation-a necessary condition for attracting foreign investment. Investors must be reassured about the quality of the legal framework and the capacity and seriousness of the government to enforce the laws and contractual obligations.

Key elements include an efficient, transparent judicial system; arbitration courts with proper enforcement facilities that can settle disputes quickly; and the absence of political intervention in the outcome of proceedings. If the court system is weak, it dramatically weakens investors' confidence.

The legal framework and laws supporting investment, domestic and foreign, must define, in clear terms, the responsibility and obligation of the parties-who does what and which ministry or agency has the authority to implement the government's policy decisions. This includes passing laws that define in a clear, unequivocal manner the responsibilities of the agencies involved. Such clarity is crucial for investors, who need to know who has the authority to approve investments and issue licenses - not to mention the scope of that authority. 
The legal infrastructure must take into consideration all aspects that are important to the potential investor. Investors searching to invest in a country need to know how the government addresses legal issues such as formation of business, enforcement of contracts, private ownership, transfer of property, security arrangements, taxes, repatriation of profits, and foreign exchange dealings. All of these should be clearly and unequivocally defined in the laws.

Accounting and financial reporting must match international standards. And in drafting the laws, one important consideration is to reexamine other existing sectoral laws-banking laws, tax laws, and so on-to harmonize them with the general trend of liberalization policies so that they do not conflict with one another. In formulating private sector policy, domestic and foreign, care should be taken not to go beyond protecting the general public interest to protecting private interests.

For countries that do not have a well-defined legal system, it may be more efficient to have a specific law for foreign investment that addresses most of the legal issues, including approvals and tax treatment. It is helpful for investors to find, in a single comprehensive document, the main legal provisions related to foreign direct investment and incentives provided by the government, thus leaving little room for interpretation and discretion. This will reduce opportunities for corrupt activities and ensure that the investment liberalization schemes are operated with fairness and consistency. What is more important, it sends clear, positive signals to potential investors that the governments welcome foreign investment. And it is very important that such legislation be in place prior to undertaking foreign investment campaigns in order to reduce delays and to avoid frustration. Of course, any changes in the law should be immediately communicated to the institutions responsible for implementing them.

\section{Institutional Reform}

The third point I would like to talk about is the reform of institutions. Laws governing foreign investment, however well drafted, are not, alone, sufficient to attract or to regulate investment. It is imperative that an overall institutional framework for business activities be set up. It is the efficiency of implementing policy decisions that will determine the attractiveness of the country to investors at large and, consequently, the rhythm of industrialization. 
Because foreign participation requires approvals, permits, and licenses from several ministries, several of which may hold differing perceptions of a given project, it is desirable for the government to streamline administrative procedures so that investors only need to deal with one government office to obtain and renew approvals. Consideration can also be given to the issue of automatic approval and clearances in some cases.

The policies and responsibilities of such a one-stop shop should be coordinated in advance to ensure speedy decisions, and the team of people representing the various ministries should have relevant competencies and authority.

At the level of customs and excises, bureaucratic procedures should be streamlined, so that delivery of inputs can be effected in time. In the absence of an efficient administrative system, reforms to attract investment may be negated. The government should consider establishing an arbitration court for commercial disputes, and set up agencies at home and abroad to provide assistance to identify market outlets and joint venture partners.

In conclusion, I wish to point out that Africa needs to take concerted action on many fronts. It has to improve infrastructure (physical, human, and financial), formulate an appropriate legal and regulatory framework, and create and maintain institutions for upgrading human capital, as most foreign investors are interested in countries where they can produce to international standards of quality and price to sustain comparative advantage. In essence, therefore, Africa would benefit greatly by adopting a global approach to investment.

\section{Iain T. Christie}

It is an honor and a pleasure for me to be with you today to discuss Africa's adjusting to the challenges of globalization. Rather than make a speech that would repeat many of the excellent points already made, let me build on some of the points from the two earlier presentations, with a view to provoking some debate. I would also like to refer to the points Motomichi Ikawa made in his opening speech, relating to agriculture and regional integration.

Let me start with the proposition that Africa's current relatively high growth rates, coupled with the low investment rate, are not sustainable. There has been a return to growth as macroeconomic sta- 
bility has been established. Indeed, with substantial underutilized capacity in some economies, growth has taken place relatively quickly, but we are going to reach a ceiling soon. Investment levels will have to rise to over 20 percent from 16-17 percent if growth is to be maintained. This is not as high as the Asian countries that have been cited, but nonetheless much higher than current levels.

The World Bank Group is doing its part to promote trade and investment by helping governments make the transition from public to private finance. The recently approved partial risk guarantee is one item. We are looking at a short-term trade guarantee for those wartorn countries where a mechanism to kick start private investment is needed and, in agriculture, we are looking at an agricultural input guarantee instrument. More broadly, we are implementing a World Bank Group strategy for private sector development in Africa that draws on the resources of all members of the Group, including the International Bank for Reconstruction and Development, IDA, International Finance Corporation, Multilateral Investment Guarantee Agency, Foreign Investment Advisory Service, and their agencies.

Most would now agree that macroeconomic reform is an essential, but not sufficient condition to ensure a supply response. Florian Alburo reminds us of a very difficult situation: how are we going to make choices, and how are we going to prioritize? It is often clear what the choices and the priorities are, but somehow, when push comes to shove, we prefer to cut programs across-the-board, rather than eliminate some.

Related to choice, of course, is the question of transition. How do economies make the transition from one environment to another? Many small countries in Africa have switched from a closed economy to an open economy rather quickly under adjustment. In the resulting small open economies, many small- and medium-sized firms have had difficulty competing, and, in fact, many have failed. For those firms that are uneconomical, this is inevitable. But one worries about the losses incurred by those firms that failed but would have survived had the transition been more gradual.

I would like to stress the importance of a policy dialogue with all stakeholders. Too often in Africa, the private sector looks at the government as the problem, and the government looks at the private sector as the problem. That gap must be bridged effectively. We tend to think that agreement with the government is all that is required for a policy framework to work. But it has been proven over and over again in Africa that "stroke of the pen" reform does not 
work. There must be more public/private debate of policy options. Until the private sector comments on policies, and until their point of view is taken into account in adapting policies, it will be very difficult for policy reform to succeed.

Alburo talked about privatization, and, indeed, this is one of the ways of addressing the high service costs that many African economies face. It is not privatization for its own sake. Rather, privatization implies an environment where competitive firms are able to deliver goods and services efficiently, in terms of timeliness, value, and cost. Typical cases are electricity, water, and telecommunications, where regulation is particularly important, as many privatized utilities remain as monopolies. For example, in Africa, telecommunications markets are typically small and operate under monopolistic conditions, but have very high revenue per line. The world trend is just the opposite-it is for opening the telecommunications sector to competition, increasing market penetration, with reduced revenues per line. In the Central African Republic, revenue per line is $\$ 1,800$, while in the United States it is in the order of $\$ 800$. Privatization has to be looked at in a broader context than the transaction itself, to include market structure and the policy environment. In fact, it is much more important to introduce competition (by bringing in a cellular operator in telecommunications, for example) than it is to simply privatize the national carrier.

The point has been made that publicly provided infrastructure has a high cost in Africa. We must rely more on the private sector to provide both the management and capital. In some countries, perhaps Côte d'Ivoire is the first among them, there has been a transition to private sector participation in infrastructure (power generation, water supply, and telecommunications). Over 20 countries are following that lead, including Cameroon and Kenya, where not only small companies are being privatized (or liquidated), but also big utilities and agribusinesses (rubber, palm oil, and bananas).

\section{Legal and Regulatory Reforms}

I would now like to address the legal and regulatory environment. There are perfectly sound laws on the books in many African countries, but they are not supported by the institutional underpinnings that make things work better. I would cite the example of agriculture in Uganda. Much has been done on extension services, yields, and agronomy; little has been done on the institutional side to en- 
sure that agricultural policy can actually work. The supply chain and logistics system of inputs and outputs is inefficiently managed, lacks the flexibility to adapt to change, and private providers are scarce. So while research and extension are very important, attention to institutional reform is equally so-to make sure that there is choice in the marketplace. There are still many public sector institutions, such as coffee boards or tea boards, that are inefficient-too many public intermediaries where the private sector might be more efficient.

One case that has worked quite well is trade and fiscal reform in Central Africa. Following trade and fiscal reform, Gabon made every effort through training and technical assistance to ensure that the value-added tax and common external tariff both worked. Without this institutional effort, the policy reform would have been much less likely to succeed. Similarly, as has been pointed out, once the economy in Mauritius was liberalized, a key element to ensure success was the institutional reforms made to support economic policy reform.

Another case that was quite illuminating was maritime transport in West Africa, where there was huge institutional resistance to change. Yet, as soon as the system was liberalized, and the institutional underpinnings were put in place, maritime transport costs in West Africa came down rapidly. Most products are about 20 percent cheaper than they were before liberalization.

With macroeconomic reform well launched in Africa, more time needs to be spent on those regulatory reforms that affect firms. Two main areas are: setting up rules of the game, including dispute resolution; and helping firms to be more competitive. Judicial systems are often weak in Africa and court systems are fraught with delays and inefficiencies; I will come back to that in the regional context. In the interim, many businesses and business organizations put the emphasis on interim solutions such as arbitration courts and ways of enforcing contracts that do not require going to the formal judicial system.

Much more needs to be done to help firms become more competitive-to increase productivity-starting with a stable macroeconomic environment. Modern business laws are part of the equation, as are clear rules for competition and regulation. This includes equitable taxation systems and transparent investment procedures; labor laws that do not severely impede a firm's ability to hire and fire as business fluctuates; and access to technology and human resource development. It is also important that firms com- 
municate with each other, through business and professional organizations, which can provide a means of acquiring knowledge and training. Such measures are central to achieving sustainable growth in Africa today.

\section{Regional Integration}

Motomichi Ikawa referred to regional integration in his opening remarks. The World Bank is supporting the Second Tokyo International Conference on African Development through the Global Coalition for Africa. The West African Economic and Monetary Union, and the Central African Customs and Economic Union, are expressions of a common interest for regional trade and investment-which are outward looking —as a stepping stone to globalization. Regional competition, regional markets, and regional support systems are all vital. The reform of the legal environment in West and Central Africa under the Organization for the Harmonization of Business Law in Africa provides countries an opportunity to leapfrog years of deficient judicial environments and move to a more modern framework.

Similarly, there are many opportunities for harmonization and cooperation in East and Southern Africa. The East African Community is looking at, among other things, harmonizing capital markets, the banking system, and infrastructure. Given the small size of many capital markets in Africa, this regional approach is a very important way of reaching out to the world economy.

Lastly, I would like to refer to the efforts of the West African Enterprise Network, a network of young independent businessmen and women that has really helped improve the dialogue between the public and private sectors on trade and mobilized investment for the region. Similar organizations are currently being set up for East and Southern Africa. 


\section{General Discussion}

\section{Regulation and Private Investment}

Hirohisa Kohama of Japan opened the discussion by asking the speakers what the private sector's role should be in designing the regulatory framework, since private sector participation was essential to ensure a realistic framework. Vina-Seeburn Dabeesingh of Mauritius cited her own country's case, where the private sector was closely consulted on all policy decisions, typically through formal mechanisms, such as the Joint Economic Council and Chamber of Commerce.

This type of approach was supported by Iain Christie of the World Bank, who suggested that a private sector interface imposed discipline-an environment where decisions were taken jointly so that one party could not back out. Often, the World Bank ran into situations where the minister of energy, for example, opposed privatizing the power company, but the minister of finance said the government would go ahead anyway, a situation that did little to build private sector confidence. The more the government was forced to face the private sector, the more it was forced to harmonize its view. The same pertained to the private sector, where the government was often faced with sharply divergent views. The public-private consultation process thus was not just a "touchyfeely" way of involving all stakeholders, but a hard-nosed way of securing better and more credible policies. In essence, Africa would be building on Asia's experience, notably Korea's and Singapore's.

Florian Alburo of the Philippines stressed the need to go beyond the "organized" private sector, as chambers of commerce typically left out nongovernmental organizations and small businesses. What was important was to have as broad a base as possible for consultation, without committing to respond to every concern raised by the general public. Hak KukJoh of Korea urged Africa not to delay 
on deregulating foreign direct investment, as Korea had done, largely because of misguided worries about losing sovereignty over economic policymaking.

Daniel Ramarokoto of Madagascar cautioned that, in a sense, there were two private sectors involved, at least in Madagascar-the preexisting one, which enjoyed a privileged position and was thus reluctant to support liberalization efforts, and the one that policymakers now wished to promote, including through outside investment. When Madagascar consulted with the preexisting private sector on a new competition law recently, the result was a law that was more conservative and protective than before. In the end, it had to be reviewed and revised.

Mansour Cama of Senegal pointed to Senegal's formal framework that had been set up to facilitate a dialogue between the private sector and the government - and sometimes even the trade unions-a framework that existed in many West African countries. He also pointed to all the progress that had been made in Africa in recent years on the macroeconomic front and in some of the structural areas. Yet, despite the reforms and good results, private investors were not rushing in. What was the problem? Cama, speaking for the private sector, suggested that the problem was, in part, Africa's image to the rest of the world-what co-chairman Motomichi Ikawa later referred to as "the image gap." He suggested that African governments, and Africans in general, perhaps with their partners, should do a lot more to project a positive image for investorsechoing Dabeesingh's call for policymakers to get out the word on reforms already undertaken and progress made.

What should countries be doing to convince investors to invest? On this question, Kwesi Botchwey of Ghana urged participants to try to prioritize, given Africa's limited capacities. Tomáz Salomão of Mozambique cited political stability and then capacity building in the public and private sectors as key. After all, without the capacity to implement decisions, little would result from decisions taken except frustration.

Jean-Claude Brou of Côte d'Ivoire agreed on the need for capacity building, noting that with the private sector driving the economy, governments had to have the capacity to regulate the environment. But he also stressed the need for macroeconomic stability, pointing out that the CFA franc devaluation in 1994 had been a turning point for his country in terms of attracting private investment. A competitive real exchange rate, combined with macroeconomic reforms 
(such as reducing the fiscal deficit) had enabled Côte d'Ivoire to almost double investment, to 15 percent from 8 percent of GDP. Even more important, the private share of total investment had almost doubled, bringing it to 70 percent of total investment. The key was to create a better environment for the private sector, which also entailed establishing judicial security. He said the judiciary at the national level had been improved, and private investors had even been encouraged to set up an arbitration court. Moreover, regional integration in West Africa had brought an overall harmonization of the legal framework, giving investors greater security.

Edith Gasana of Rwanda seconded Brou and Cama's emphasis on capacity building and institution building, noting that perhaps the most important element was regulatory reform. But setting up a regulatory framework was not enough. Very often, laws existed that were never implemented.

Botchwey added to this list of priorities the need for information sharing, to avoid having decisions be governed by ignorance; buildup of infrastructure; regional integration; and financial sector reform. On the last priority, Piero Ugolini cited an IMF study showing that a major problem for the private sector was its very limited access to credit. In fact, for sub-Saharan Africa (excluding South Africa and Namibia), loans to the private sector generally represented only 20-25 percent of the portfolio of commercial banks. This contrasted sharply with Asia, where, despite the financial crisis, the figure was about $70-80$ percent. He said the problem was that the banks saw private sector credit as risky, preferring to invest in treasury bills-one reason why the IMF counseled fiscal discipline. Thus, it was no coincidence that those African countries with large domestic debt loads were the same ones with a low percentage of bank loans to the private sector.

Christie picked up on the risk question, suggesting that it was much overplayed in the media. He cited a recent World Bank study that showed that rates of return in Africa were 25-30 percent, significantly higher than the 16 percent worldwide. True, risks were also somewhat higher in Africa, but this just meant that investors should manage risk by diversifying their portfolios. In response to a question from Gasana on why the World Bank was reluctant to support fiscal incentives for foreign investment, he pointed out that Brou had not cited such incentives as a reason for Côte d'Ivoire's higher foreign investment. Much more important, Christie said, was maintaining a stable and predictable investment environment. 
Gray Mgonja of Tanzania, however, supported Gasana, saying fiscal incentives were needed in the short run, when a country was struggling to establish an attractive regulatory framework and when its neighbors offered them. He also suggested that the private sector would feel more confident if there were not a perception that reforms were being "imposed from outside." In other words, how could the private sector know the government would stick to a certain position if it was constantly being swayed by outsiders?

Godfrey Simasiku of Zambia closed the discussion by urging investors to try to understand Africa better-a continent rich in human resources, raw materials, and culture. He also reminded participants of the challenges of switching to an open market economy, as jobs are lost and civil servants become insecure. "We are being portrayed as a government that is not listening, a government that does not care. Then in two years' time, we have to fight and defend ourselves in an election." 


\section{4}

\section{Developing Sound Banking Systems and Practices in Africa}

Piero Ugolini

$I^{t}$ $\mathrm{t}$ is a singular privilege for me to participate in this seminar on challenges of globalization in Africa. The theme of the conference is both topical and timely, considering the recent progress made and the challenges faced by the sub-Saharan African countries in the area of financial sector reform. Banking soundness and the need to contain moral hazard and promote market discipline are the issues of the day, particularly as a result of the Asian crisis. In reality, these are concepts that have existed for a long time in the financial world and often have been neglected until a financial crisis emerged. Franklin D. Roosevelt stated in 1933, in the aftermath of the Great Depression:

"As to guaranteeing bank deposits, the minute the government starts to do that the government runs into probable loss. We do not wish the United States government liable for the mistakes and errors of individual banks, and put a premium on unsound banking in the future."

The existence of a sound banking system in African countries is a relatively new concept and challenge. Since independence, about 30 years ago, the financial sector in these countries has undergone domestic changes and evolution, sometimes not intended and not always favorable. It is only recently that the soundness of the financial sector has become relevant and important. As a result, 
some actions have been taken by these countries to develop financial sectors, and in recent years, some progress has been made. But much remains to be done. The need for these countries to do more is made even more urgent and essential, given the increasing globalization of the world economy. Globalization poses a real threat to Africa's further marginalization, but it offers at the same time a welcome opportunity to speed up economic growth and development, and to raise living standards, if efforts are made and maintained towards achieving lasting macroeconomic stability. The bottom line is that Africa will have to accelerate structural reforms, particularly in the financial sector, if it hopes to attract large volumes of capital investment.

So where do financial sector reforms in Africa stand and how can the IMF help? My department, the Monetary and Exchange Affairs Department, recently conducted a study on this very topic. We took a sample of about 35 countries, primarily focusing on central bank operations and the central bank framework, just touching lightly on the banking sector and nonfinancial institutions.

I would like to share with you some of the results, describing briefly how the financial sector has evolved, the key existing problems, and suggested reforms and their sequencing.

\section{Overview of Financial Sectors}

After independence, owing to prevailing political ideologies, expansionary economic policies, and different types of influencesincluding internal and external shocks, such as the sharp increases in petroleum prices and the deterioration in African countries' terms of trade-real growth was severely impaired and inflation extremely high. During the 1970s and 1980s, the growth rate of GDP at constant prices declined and was about one-half the average rate in developing countries as a whole. Inflation was, on average, 25 percent a year.

During this period, Africa placed a great emphasis on developing and protecting the real sector. Government intervention and protectionism became the main policies to develop the domestic economy. This was done largely through directing preferential credit to the real sector, especially agriculture and public enterprises. In other words, the financial sector was accorded only an ancillary role in the development process, that of channeling credit to the govern- 
ment and preferential sectors, without assessing the risk and efficiency of such credits.

The net effects of these developments on the financial systems were that financial institutions were weakened, financial instruments became irrelevant, the credibility of financial policy was eroded, and parallel markets effectively marginalized the formal financial sector. Under these circumstances, the development of the financial sector was severely constrained for a number of reasons:

- The central bank was seen as part and parcel of the government machinery, designed mainly to provide credit to the government. And since there was no monetary policy initiative to be taken, the issue of central bank autonomy did not even arise.

- Whatever financial market there was, existed simply for the sale and purchase of government treasury bills at predetermined interest rates, although the bulk of the loans to the government were granted through ways and means advances (direct credits at zero percent interest).

- Because the regime was characterized by direct credit to government and parastatals, which had neither the ability nor the incentives to repay debts, the portfolios of the commercial banks were severely burdened with nonperforming loans. The commercial banks, in turn, did not provide for nonperforming loans, as they were loss-making and poorly capitalized. Capitalization of state-owned banks, of course, had direct budgetary implications and hence was ignored. Virtually all development banks became insolvent and illiquid. Competition within the banking system was limited and in some cases nonexistent, because of controls over most, if not all, prices, including interest rates and exchange rates.

By the late 1980s and early 1990s, faced with a deteriorating world economic picture, African countries embarked upon a policy of adjusting their economies and dismantling controls and restrictions that had become institutionalized. This adjustment was generally implemented within the context of IMF- and World Bank-supported stabilization and structural adjustment programs (the structural adjustment facility, or SAF, starting in 1986, and the ESAF, starting in 1987). In fact, by end-1996, 21 out of 48 African countries were implementing these programs. 
The reform measures included fiscal and financial measures to reduce inflation, open up the trade and payments system, and liberalize prices, production, and marketing of most goods and services. The measures also included structural measures to avert the need for repeated depreciations of the domestic currency and restore confidence in domestic markets. Overall, the objective was to achieve noninflationary, private sector-led growth within a marketbased economic system.

Importantly, as part of the overall adjustment program, a large number of African countries also undertook financial sector reforms. These reforms included liberalizing interest rates and eliminating administrative allocation of credits, granting more autonomy to central banks in the conduct of monetary policy, and instituting a transition from direct to indirect monetary policy instruments. These countries also began paying more attention to restructuring commercial banks to restore solvency, developing financial marketsmainly primary markets for government securities—and improving financial infrastructures, including bank supervision, auditing, and accounting practices.

African countries, as a whole, have made significant strides in adjusting their economies, with the result that growth is beginning to pick up and per capita incomes are once again on the rise. Even though the adjustment period has been relatively short, most macroeconomic indicators show significant results. Indeed, real GDP growth has, on average, doubled from its prereform level in the mid-1980s of 1.5 percent a year.

\section{Existing Problems}

Despite this recent progress, considerable work still lies ahead and financial sector reform remains at an embryonic stage. Our study highlights the following:

- Most central banks have only limited autonomy to perform appropriate monetary and supervisory functions. Government interference in credit extension, bank licensing, and supervision encroaches on fulfilling the main mandates of the central bank-that is, maintaining price stability and ensuring the soundness of the financial system.

- The financial sector suffers from a lack of competition created by the monopolistic position of large government-owned 
banks; the lack of a level playing field discourages the entry of private and foreign banks.

- The large share of nonperforming loans in the balance sheet of the largely government-owned commercial banks impedes the development of interbank markets, since sound banks do not want to deal with unsound banks.

- The absence of a complete array of monetary instruments (portfolio securities) and a dearth of expertise constrain central banks' ability to deal with the excess liquidity created by governments' expansionary policies.

- The large share of nonperforming loans, the lack of competition in the financial sector, and high administrative costs, as well as high reserve requirements, are at the root of the large spread between deposit and lending rates.

- The crowding-out effect of government borrowing pushes the interest rate structure upwards and discourages borrowing for long-term investment. What is puzzling is that commercial banks often seem to be content to hold excess reserves, earning no interest, yet demand from potential borrowers in the private sector goes unmet-forcing these borrowers into the informal financial sector.

- The regulatory framework for supervision is moving toward full compliance with the Basel core principles, but its implementation is not always very effective. The authorities are tardy in dealing with insolvent financial institutions, owing to political and social pressures. Loan recovery is also hampered by bottlenecks in the judicial system.

- The economic and political uncertainties encourage investors to opt for short-term speculative investments, at the expense of building up savings and expanding long-term credit.

- The inefficiency of the payments system-which was not important under a highly controlled economy but takes on immense importance under a market-based system-hurts financial sector development, keeps payments system risks high, and hampers the transmission mechanism of monetary policy. In Zambia, for example, the float period for clearing checks was two weeks for Lusaka, and three or four weeks for the copper belt region. But now, with technical assistance from the IMF and the cooperation of commercial banks, it is down to only 
two or three days for Lusaka and about one week for the copper belt.

- The constraint imposed by the dearth of well-trained and qualified nationals limits the formulation and implementation of sound financial policies. This problem has persisted because of a lack of specialized institutions catering to financial sector needs.

\section{Sequencing of Reforms}

So what can we learn from other countries' experiences with financial sector reform and how should reforms be sequenced? This is undoubtedly one of the trickiest questions. We believe that a key lesson is that policymakers should begin with getting the fiscal deficit under control and establishing macroeconomic stability. Clearly, reforms cannot be carried out against an unstable macroeconomic background. The government should implement policies aimed at increasing efficiency and competition in all areas of the economy, particularly the financial sector. Indeed, the vital role of banking soundness, from a macroeconomic perspective, is a point that the IMF has been repeatedly trying to drive home.

The experience of industrial, developing, and transition economies indicates that an unsound, uncompetitive banking system, and inadequate institutional and regulatory framework weaken efficient credit allocation, distort the structure of interest rates, disrupt monetary policy signals, and impose significant fiscal costs. In Uganda, for example, broad money used to account for about 25 percent of GDP, but after a high rate of inflation took hold, broad money dropped to around 9 percent of GDP, where it remains in 1998.

Insofar as macroeconomic stability is vital for financial sector development, a sound and well-functioning financial sector is essential for guaranteeing macroeconomic stability. This dual relationship is mutually reinforcing and fully justifies the need for governments to tackle both issues at the same time. How should countries proceed? I would like to suggest bold measures in eight key areas.

\section{Legal and Regulatory Framework}

An efficient and strong financial system has to be founded on an appropriate legal and regulatory framework. The latter is indis- 
pensable for a sound financial system within which the authorities must have autonomy and be accountable for the system's operations. In order to attain a suitable level of autonomy for central banks and provide accountability, governments should do the following:

- Promulgate central bank legislation containing, at a minimum, provisions that give explicit priority to price stability as the objective of monetary policy.

- Give authority to a single institution, preferably the central bank at the initial stage, for the overall supervision of the financial system.

- Consolidate the licensing and revocation of licenses in a single unit, again, at least initially in the central bank, thereby making one single unit fully accountable for the licensing and performance of financial institutions. In Africa, responsibility for licensing is often split between the central bank and the finance ministry. As a result, the finance ministry sometimes grants licenses, under tremendous political pressure, to which the central bank objects.

- Require an institutionalized, transparent mechanism for resolving divergences between fiscal and monetary policy.

- Ensure that governors of central banks and members of boards of directors do not come under undue political influence, possibly through careful legislation. In many African and some Asian countries, there is no official appointment for the central bank governor, meaning that the governor can be removed by the prime minister on a whim. At the other extreme is Italy, where the governor is appointed for life.

- Place explicit and reasonable limits on the amount of credit that can be granted by the central bank to the government and ensure that these credits are collateralized by income-yielding assets, bearing market-determined rates. In Poland, for example, the government moved quickly in 1989 to amend the central banking law to limit credit to the government, paving the way for tremendous progress in the financial sector.

- Do not impose on the central bank the obligation to undertake quasi-fiscal activities, and ensure the financial viability of the central bank.

- Improve the judicial system to accelerate recovery of bad loans. 
Well-conceived legislation, however, only represents a necessary condition for central bank autonomy. A sufficient condition would be the commitment by governments to ensure compliance with the provisions of the legislation. In this regard, it could be useful to set up independent, specialized courts that deal only with matters relating to the financial sector. This is likely to speed up the settlement of financial contractual cases and, above all, send a clear signal regarding the direction and intention of the authorities.

The recent Asian crisis has underscored the importance of separating the monetary authorities from the "political establishment," and providing autonomy and authority for prompt actions.

\section{Supervision}

As economic stabilization has progressed in Africa and inflation rates have come down, there is a need for commercial banks to strengthen balance sheets, increase provisioning for nonperforming loans, and strengthen credit and market risk analysis. Thus, firm, timely, and effective supervision is essential to ensuring that these imperatives are followed. This means adopting international, bestpractice accounting standards, complying with the basic supervisory standards relating to prudential regulations-as indicated by the Basel Committee's Core Principles for Banking Supervision-and putting in place examination procedures, including on-site inspections and off-site surveillance, that are capable of identifying weaknesses.

The recent Asian crisis clearly shows how the lax prudential supervision of financial institutions can undercut economic progress. In most of the Asian crisis countries, the minimum capital adequacy ratio of 8 percent was met, at least on paper, by most banks. But this was only because most of the insolvent banks adopted unconventional accounting practices and misclassified assets.

In dealing with the Asian crisis, the IMF has emphasized the need for a comprehensive financial restructuring strategy to restore confidence and reestablish the soundness of the financial system. Broadly speaking, the IMF-supported programs have included efforts to:

- identify and promptly close insolvent institutions;

- recapitalize and restructure weak but financially viable institutions; 
- strengthen the operational viability of financial institutions through introducing internationally accepted best practices in the areas of asset valuation, capital adequacy, accounting, and public disclosure;

- improve the regulatory environment and compliance; and

- enhance competition and efficiency, including through measures such as the eventual privatization of state-owned financial institutions and increased foreign participation.

\section{Payments System}

Besides South Africa, which has a fairly well-established payments system-and the South African Development Community and CFA franc countries, which have begun to address payments system policies and procedures - the modernization of payments systems in the rest of Africa has been neglected. Indeed, these systems are in dire need of restructuring to avoid systemic risks and failures. Apart from the bottlenecks that are created in effecting settlements, the weak payments systems impose serious constraints on developing other aspects of the financial sector, because of their interface with monetary operations and instruments and with the core financial markets. Additionally, given the rapidly increasing use of banks in African countries, juxtaposed against the still predominant use of checks as the main instrument of payments, urgent steps are called for to modernize the payments systems.

The experience of other countries, such as Poland and some others in Eastern Europe, that moved from direct to indirect instruments of monetary management, shows that large and erratic float movements hinder the transmission mechanism of monetary policy implementation. Such floats create a problem for forecasting shortterm (daily and weekly) liquidity and force banks to hold large excess reserves in order to avoid settlement penalties. This impairs the profitability for banks, which then pass on the cost to consumers by widening the spread between deposit and lending rates.

\section{Accounting and Internal Audit}

In this area, while we can identify a few good examples of central bank accounting and internal audit reforms, progress for the vast majority of countries has been slow. Why the slow pace? The 
main reason, especially for former centrally planned countries, which are faced with the task of reinventing accounting systems, is a problem of perception. Accounting is still considered a bookkeeping and recording function that does not rank as a high priority in most countries. Regrettably, policymakers fail to appreciate the close links between an increasing reliance on market forces and access to timely and reliable information for sound decision making. Thus, efforts must now focus on education, if Africa is to modernize its accounting systems and establish an internal audit system capable of examining, evaluating, and monitoring the adequacy and effectiveness of accounting and internal procedures.

\section{Sound Banking System}

Good economic policy needs a sound banking system. Unsound banks threaten the real sector, weaken monetary policy, impose fiscal costs, and produce exchange rate instability. Given the financial sector's vulnerability to wrong policies, it is essential that authorities create a level playing field where sound competition can guarantee efficiency and better services to the population.

In most African countries, government-owned (and even partly owned) banks dominate the financial sector. Their inefficiency is reflected primarily in large spreads between deposit and lending rates and weak financial intermediation. Injecting competition in the financial sector by splitting and privatizing government-owned banks is critical for developing the interbank market and secondary trading activities. In addition, the portfolio has to be diversified. This means the portfolio of risks, credit, market, on- and off-balance sheet has to be well spread. The bank has to be profitable. After all, a loss-making bank will rapidly degenerate unless drastic steps are quickly taken. The bank has to be liquid and well capitalized and should eschew undue risks that arise from acquiring low-quality assets and taking inappropriate domestic and external positions. Apart from the high levels of integrity expected of management, a sound bank has to have in place prudent credit approval procedures, risk limitations, and appropriate internal credit control.

To preserve and ensure soundness-and here I would like to recall the old adage that a sound bank is only as sound as its management-policymakers must provide discipline and incentives for good management by emphasizing the transparency of banking activities. 
- A sound banking framework should produce timely and reliable information for use by management, supervisors, and market participants.

- There should be public disclosure by banks to the market, and rating agencies should be encouraged in order to facilitate private sector credit activities and develop capital markets.

- Banks should report regularly to supervisors all relevant information, including market-sensitive developments, drawing on international, best-practice accounting standards.

\section{Limiting Public Sector Distortions}

How about when banks are in crisis, raising dilemmas for the supervisory authorities?1

Lender-of-Last-Resort Facilities. The role of lender-of-last-resort by the central bank has often been wrongly used to support insolvent banks and undermines the discipline and profitability of the banking system. The true role of the central bank, instead, should be to provide temporary assistance to illiquid but solvent institutions. To do this effectively, the central bank must be able to distinguish between illiquid and insolvent banks, and this means having access to all the relevant information.

Exit Policy. A sound banking sector needs a credible exit policy to deal with insolvent banks. Here, too, timely and reliable information should be available to supervisors. Moreover, an appropriate legal framework must be in place to ensure that if banks are closed, it is done strictly on financial grounds-in other words, free from any political interference.

Deposit Insurance. Deposit insurance schemes are prone to problems of moral hazard. They should be designed and implemented as insurance in the event of a bank failure-not as a panacea or substitute for strong supervision. In Africa, encouragingly, we are beginning to see some deposit insurance schemes implemented for the purpose of protecting those with small savings.

\footnotetext{
${ }^{1}$ For details, see David Folks-Landau and Carl-Johan Lindgren, Toward $a$ Framework for Financial Stability, World Economic and Financial Surveys (Washington: International Monetary Fund, 1998).
} 


\section{Capacity Building}

The IMF study clearly identifies the need to develop human capital, so as to expand the professional class of qualified nationals able to efficiently operate the monetary and exchange rate systems. Indeed, African countries, as a whole, still lack sufficient numbers of financial regulators, supervisors, and managers who could maintain high professional standards.

What can be done? The IMF-in close coordination with the World Bank, other bilateral and multilateral institutions, and possibly regional African organizations-could set up well-focused technical assistance programs. These should effect the required transfer of knowledge to develop human capital and improve existing structures.

\section{Conclusion}

For African countries to undertake the necessary reforms that have been outlined above, two vital and complementary courses of action need to be speedily embarked upon. First and foremost, African governments must make a strong commitment to reform and demonstrate strong leadership if they hope to create an atmosphere of economic security and good governance within which reforms can take place.

Second, Africa needs to develop local capacity for the efficient design and implementation of monetary and exchange rate policies on a routine basis. Of course, there are technical, institutional, and human resource constraints facing most African countries. This is where the international community - the IMF, the World Bank, and other bilateral and multilateral institutions-can help, by supporting reform efforts through the provision of technical assistance and training. The progress made so far augurs well for the future. It is vital to build upon it now. Indeed, the IMF is considering how best to intensify its technical assistance program in Africa, chiefly in the areas of monetary operations, bank supervision, payments system development, and human capital development.

I would like to conclude by reiterating that banking soundness is essential for economic growth and we should learn from past mistakes. Unfortunately, some of the lessons of the past have not been learned well. In Florence, in the fourteenth century, two 
banks, the Bardi and the Peruzzi, were the giants of the industry. But they eventually collapsed largely because they failed to collect loans from existing monarchies, notably Edward III, King of England, and Robert the Angevin, King of Naples. The Medici family, which was a competitor of the two banks, learned from this failure and adopted a more diversified credit policy by avoiding credit concentration, spreading risk, increasing lending to private traders, and reducing credit to the royal families. The Medici Bank became one of the strongest in the world, dominating the financial world for over a century, until political forces, mostly from Rome, sought to destroy its business and accelerate its fall. In the end, the Medici family was expelled from Florence during the French invasion of 1494.

Thus, it is proper, a little more than 500 years later, to pose the question: Is political interference still contributing to banking crises? 


\section{Relevance of Banking Lessons for Africa: Zimbabwe's Experience}

Leonard Tsumba

$\mathrm{T}$

he rapid technological changes that have taken place during the last two decades have seen the world increasingly shrink into the global village. Barriers to economic relations are progressively disappearing, giving rise to new regional economic blocs and to deeper integration among existing ones. These developments have further intensified the integration of national economies.

Underpinning this trend has been the implementation of macroeconomic reforms in most countries throughout the world-with most notable benefits accruing to those regions that embarked early and quickly in integrating their economic and financial systems with the world economy. These regions include South East Asia and some countries in Latin America and recently, Africa and the new European democracies.

In response to the economic reforms and liberalization of financial markets, the world has seen a massive growth of cross-border capital flows, although very little of these flows have found their way to sub-Saharan Africa. Indeed, while private capital flows to emerging markets rose to $\$ 235$ billion in 1996 from $\$ 192.8$ billion in 1995 , those to Africa declined to $\$ 9$ billion from $\$ 13.6$ billion. The world has also seen a rapid removal of trade barriers, such as import licensing and other nontariff barriers, along with the deregulation of domestic controls - all aimed at creating an inviting business and investment climate. 
As we, in Africa, begin to fully appreciate the implications of globalization and deal with the attendant challenges it poses, solutions remain elusive. The challenges we face include maintenance of an enabling macroeconomic environment, liberalization of our foreign exchange arrangements, deregulation of controls on investment, aggressive promotion of exports, and the further liberalization and development of our financial systems. Yet, if we are to assume our role in the international economy, it is time that we respond to these challenges.

Thus, it is critical that we integrate our financial systems with the developed international financial markets. Over the last decade, major strides have been made to upgrade our banking systems, but much remains to be done if we are to develop systems and practices that are compatible with international standards. While this is going to be the main focus of my presentation, I have taken the liberty of first addressing some of the challenges of globalization that require our urgent attention.

\section{Challenges of Globalization}

So what are these challenges? It is inconceivable that sound banking arrangements can be achieved under conditions of macroeconomic instability. Thus, a key success factor-and challenge-would appear to be finding the political will to adopt appropriate policy reforms to achieve price stability. Experience suggests that countries, such as Mexico and Thailand, that embarked on financial liberalization before undertaking other macroeconomic reforms have suffered from destabilizing capital flows, high interest rates, and corporate distress.

For Africa, no doubt the biggest macroeconomic challenge will be to tame inflation, which still acts as a major impediment to growth and further economic and financial integration. Countries such as Malawi, Tanzania, Zambia, and Zimbabwe in Southern Africa have, in the recent past, experienced inflation levels in excess of 15 percent. This has resulted mainly from the need to finance large budget deficits through domestic and foreign borrowing-a development that has trapped some of our economies in a vicious circle of high domestic and foreign debt. The resultant high taxation levels have undermined production and investment.

The only way African economies can hope to reduce investment risks, which accompany high nominal interest rates and the crowd- 
ing out of the productive sectors, is to bring about stable but low inflation. Overall price stability is vital for the successful development of financial markets because of the linkages between expected inflation, real interest rates, and exchange rates, as well as the way these relationships affect the allocation of investment resources. Each country must first put into place the right fundamentals. This will require, of course, prudent fiscal and monetary policies.

Another challenge of globalization is liberalizing foreign trade. On this score, much progress has already been made throughout Africa over the past decade. Both foreign exchange allocation and the determination of the price of foreign exchange are now being undertaken in a market setting. This means that financial institutions have had to adjust their operations and banking practices to manage these new responsibilities, previously a prerogative of central banks.

Trade liberalization brings with it stiff competition from all corners of the world. For Africa to benefit from the new order, therefore, it must adopt aggressive policies to promote both nontraditional exports and economic activity in general-a challenge that unfortunately will take time to address. This is especially so, given the current glaring asymmetries in economic fundamentals between the industrialized and developing economies.

One solution might be for African governments and the private sector to form some sort of "smart partnerships" to ensure that the private sector is able to generate enough foreign exchange to meet the cost of capital goods imports, as well as to service external debts, without interfering with market arrangements.

Liberalized capital account positions ensure even freer capital mobility, but full currency convertibility remains a major challenge given the limited capacity of our financial systems to intermediate large volumes of international capital flows. Development of financial systems to cope with this can only come with further banking sector reform and sound supervision, supported, of course, by fiscal and monetary discipline.

The development of sound banking systems and practices, however, is meaningless unless undertaken in an environment conducive to both domestic and foreign investment. This means that governments need to adopt transparent, consistent, and predictable procedures and policies. A major objective should be the establishment of international standards, consistent with the expectations of foreign investors. Such standards include security of investment, and the timely and consistent enforcement of legal provisions. 


\section{Sound Banking Systems and Practices}

African economies have much to learn from the experiences of some South East Asian economies that have benefited from the transformation of their financial systems. In spite of recent setbacks, these countries have been able to realize sizable capital inflows, in both equity and direct investment. Indeed, of the total $\$ 235$ billion private capital flows to emerging markets, almost one-half ( $\$ 106.8$ billion) has gone to Asian economies.

For Africa, globalization and the opening up of economies has brought a rapid increase in the number and range of banking institutions, nonbanks, and products and services on offer to customers. In Zimbabwe, for example, the number of deposit-taking or banking institutions has jumped to 33 in 1998 from 18 in 1990. In Mozambique and Tanzania, the state monopoly of the banking industry has been removed, and the more enterprising private sector has been allowed to take over. Besides traditional banking services, tailor-made products are now offered at competitive prices, and the quality of customer care has generally improved.

But the important question is have these changes brought enhanced credit delivery systems? It is evident that in most African countries, new market participants have tended to operate on the margin. This means that new financial institutions have often come on board highly undercapitalized, lacking the capacity to challenge the already established institutions. With a lack of effective competition, antiquated banking practices have continued to exist, as seen by the super-normal profits characteristic of African banking. In Zimbabwe, for example, banks' margins are significantly higher than those in the more developed financial markets.

There are also numerous bank failures resulting from aggressive banking and a scramble for market share in an environment of poor supervision, coupled with frequent interventions from political circles. ${ }^{1}$ There is imprudent lending, stemming from inadequate regulations and supervision-as well as limited experience among financial institutions in risk pricing and management, a lack of commercial orientation, poor corporate governance, and lax internal controls. And the problems are compounded by a weak physi-

\footnotetext{
${ }^{1}$ Recent cited examples include Zambia. See Carl-Johan Lindgren, Gillian Garcia, and Matthew I. Saal, Bank Soundness and Macroeconomic Policy (Washington: International Monetary Fund, 1996).
} 
cal and financial infrastructure, a low skills base, a weak human and institutional capacity, a low level of savings, a heavy debt burden, and small and fragmented markets.

Thus, the challenge facing authorities is to ensure that Africa reaps the promised implied benefits from deeper and more developed financial markets, and from more effective financial intermediation. No doubt the answer lies in better supervision, a sound legal and regulatory framework, an efficient national payments system, and capacity building.

\section{Supervision}

In the normal course of operations, it is imperative that the authorities monitor closely the performance of the deposit taking institutions through both on-site examinations and off-site analysis and surveillance. This means focusing on the usual prudential standards relating to initial capital and capital adequacy, asset quality, management, earnings, liquidity, insider lending restrictions, legal lending limits, full disclosure, and internal governance-as failure to follow these standards will inevitably lead to bank failures and the danger of contagion risk. In setting the standards and the regulatory framework, the authorities should take into account the experiences of other countries and incorporate objective and internationally acceptable guidelines - which must then be strictly adhered to.

Affirmative action-an important issue in a number of African countries-needs to be handled carefully and through specific measures, without attempts to lower or vary agreed regulatory standards. It should be noted that the achievement of sound and safe banking is facilitated in an environment that is not characterized by political influence, whether this be at the registration or liquidation stage, or in regard to other banking arrangements.

The performance of the banking institutions depends, to some extent, on the growth and development of the financial markets. However, banks should themselves be in a position to disclose, in a timely manner, as much accurate information as possible to their stakeholders - the owners, directors, management, government, and the public at large. This will go a long way toward eradicating the moral hazard problem that is prevalent in Africa, where the public generally believes that bank deposits are either guaranteed by the government or that banks will not be allowed to fail. Similarly, the public should be encouraged to choose banks on the basis of safety. 
While the primary focus, from a prudential supervisory perspective, is on the deposit taking institutions, sight should not be lost of complementary actions that need to be taken by the authorities on reforming the rest of the financial sector. This is necessary because developments in these areas could harm the overall soundness of the banking system.

\section{Legal Framework}

It is critical that governments adopt measures to strengthen the legal framework on which standards and supervision are based. In order to avoid overlaps and gaps, it is essential that the supervisory and regulatory functions are handled by one body, either within the ministry of finance or central bank; alternatively, this can be delegated to a specialist institution or organization. The main point is that there must be accountability and clarity of roles. Policymakers, in particular, should have a thorough understanding of banking supervision.

Legislative provisions should be comprehensive and transparent, focusing on issues such as licensing and de-licensing criteria, supervisory powers, lending guidelines, provisioning, capital adequacy, good management, and corporate governance.

\section{Payment System}

In the strategic area of clearing, payment, and settlement, the central bank must play an active, leading role and be seen to be driving the planning and implementation of a robust system. The goal is to minimize the potential systemic risk that can result from a failure to settle by any of the participants in the payments process-a development that would, doubtless, disturb the financial system, with disastrous consequences for the rest of the economy.

The central bank must also focus on the increasing number of nonbanks now getting involved in the payments process and, to some degree, in the banking business. Examples include building societies, discount houses, finance houses, money brokers, development banks, pension and insurance companies, and supermarket chains. This will entail proactive analyses of the likely impact of the banking activities of nonbank institutions.

Similarly, the central bank must ensure that the development of information technology systems in the banking sector is coordi- 
nated, as this has a direct bearing on the successful operation of the clearing and payments systems, as well as on prudential monitoring and surveillance. The central bank is, of course, expected to ensure that potentially risky developments, such as the anticipated year 2000 computer systems failure, are addressed by all the financial institutions in a timely manner, so as to avoid wholesale failures of the banking systems. In Zimbabwe, some of the major banks have taken steps to ensure that their computer systems are year 2000 compliant. Furthermore, they have embarked on awareness campaigns to safeguard their clients' information technology systems against this anticipated problem.

\section{Capacity Building}

For Africa, a key strategic issue is the urgent need to develop the skills and competencies required to carry out banking operations efficiently and effectively. The problem is that the overall pool of expertise and skills is limited relative to the growth of the banking industry. This is exemplified by reliance of African financial institutions on the IMF and World Bank, as well as on consultants from industrialized countries.

African policymakers will, therefore, need to give a high priority to staff training and human resource development programs. This will strengthen the capacity to understand supervisory standards and regulations, and it will facilitate effective management, internal controls, and strict adherence to prudential requirements. The availability of adequate management skills should always be a key consideration when bank licenses are issued. And the supervisory function itself will, of course, need to be staffed by highly motivated and adequately remunerated professionals.

\section{Conclusion}

In conclusion, it is important that we take stock of the lessons that Africa can draw from the recent experiences in South East Asia. Five key lessons come to mind:

- Governments must be committed to making a success of economic, social, and political reforms, so as to ensure a stable environment supportive of sustainable economic growth. In the absence of a stable environment, the banking system will con- 
tinue to be under threat as it becomes difficult, if not impossible, to achieve conditions of soundness and safety.

- Appropriate measures should be taken to facilitate the development of stable financial markets. The experience of South East Asian countries shows that problems can start in financial markets and this can adversely affect the banks, the productive sector, and the general economy. It is interesting to note that, in this case, contagion risk extended beyond local economies and severely hurt virtually all the countries in the region-with aftereffects felt in economies further away.

- Effective external debt management is an essential and integral part of banking supervision, as an uncontrolled buildup of external debt can create undue pressures on the balance of payments. This, in turn, has a destabilizing effect on the overall economy as was recently seen.

- Governments must show the political will to maintain an enabling legal environment and support the supervisory authorities and regulatory system by refraining from political interference in policy and operational decisions that should be the realm of the owners, directors, and management.

- The recent experience of Asian economies shows clearly that the liberalization of controls and general opening up of economies under the reform process must be done under conditions of balanced and sustainable economic growth, otherwise an economy becomes dangerously overheated. This is usually characterized by distortions in asset pricing, large current account deficits, and a rapid buildup in short-term external debt.

Given Africa's limited financial resources and its poor and shallow export capacity, we cannot do without aggressive market-oriented policies. Liberalization will improve the efficiency of our financial systems to mobilize and channel savings into the productive areas of our economies. But experiences from the developed world underscore that effective trade facilitation can only be achieved through a sound and efficient banking system. The prospects of an economic boom in Africa are immense. This can only happen, however, if there is full commitment and cooperation between governments and the private sector. 


\section{Comments}

\section{James Cross}

Having heard these valuable contributions (and noting that Piero Ugolini based his thoughts on the results of a comprehensive study by the Monetary and Exchange Affairs Department of the IMF) it is perhaps safest simply to say "Amen"! All the major points and caveats regarding the development of sound banking systems and practices have been covered by the speakers.

Some points, however, deserve to be amplified and I will endeavor to do so, mainly in light of South Africa's experiences. It is heartening to see the emphasis placed by our distinguished speakers on the importance of a stable macroeconomic environment as a prerequisite for developing sound banking practices and policies. While financial market specialists and regulators seem to agree more and more on this score, it would seem that this point has not been fully conveyed to the public at large. Within the increasingly democratic environment in most parts of the developing world, further efforts at communicating the benefits of stability to the broadest audience possible will be worthwhile.

While a stable macroeconomic environment and a sound banking system may well be a necessary condition for economic success, it may not be a sufficient condition. South Africa has unfortunately not yet been able to generate sufficient economic growth to make a meaningful impact on the level of unemployment prevailing in the country. The authorities nonetheless remain committed to prudent macroeconomic policies.

It is perhaps helpful to note the reservations in many developing countries regarding the globalization of finance, reservations that flow from the perception - and often the practice-that the most solid companies active in the economy concerned use overseas banks as their lead bankers, at least for certain categories of large transactions. It is sometimes alleged that foreign or foreign- 
controlled banks simply pluck the best businesses in developing economies. The fundamental solution, although painful, costly, and time consuming, is, of course, to strengthen local human capital and to raise service levels and professionalism in the domestic banking sector. Indeed, both papers alluded to the shortage of well-trained nationals. Ironically, competition from abroad may well be needed to obtain such a transformation.

\section{South Africa's Experience}

As you are aware, the political reforms in South Africa over the past five years opened up the way for major changes in our financial sector. With the removal of sanctions, boycotts, disinvestment campaigns, and the withdrawal of foreign loan funds from South Africa, the challenge was to reintroduce the South African financial markets in the world environment-and we have gone through quite a learning curve. This reintegration took place at a time when the international markets also changed drastically, and when the trend towards financial globalization gained momentum.

During the past few years, many international financial institutions have established themselves in South Africa to participate in the expansion of our markets. Explosive increases occurred in the volume of transactions, with total turnover in the secondary bond market rising to R 4.6 trillion in 1997 from R 2.3 trillion in 1995, and the total value of shares traded on the Johannesburg Stock Exchange increased to R 207 billion from R 63 billion over the same time period. The average daily turnover in our foreign exchange market jumped to over \$10 billion in 1996 from about \$4 billion in 1994--with nonresidents representing about 50 percent of the turnover. And during the first three months of 1998, nonresidents increased their holdings of South African securities (shares and bonds) by R 17 billion.

These greater volumes brought with them greater risk exposures, and thus a need for more modern, sophisticated risk management procedures. In the area of financial regulation and supervision, we now have internationally recognized principles and procedures for financial regulation and supervision (for example, the Basel Committee directives for bank regulation). Moreover, the importance of independent, well-trained bank supervisors is widely recognized. To quote Ugolini: "Unsound banks threaten the real sector, weaken monetary policy, impose fiscal costs, and produce exchange rate instability." 
The South African Reserve Bank also fully recognizes the value of on-site and off-site surveillance to identify weaknesses in a timely manner-and we have instituted these forms of surveillance. As an aside, there might be some divergence of opinion regarding whether overall supervision of the financial system should be concentrated in the central bank. My feeling is that with institutional capacity often limited in developing countries, the case for housing supervision in the central bank is the more persuasive.

Turning to an efficient domestic payments system-the importance of which was underscored by both Ugolini and Tsumbathere has been much activity on this front. The growth in value transferred through these systems, as well as systemic risk inherent in the clearing and settlement of payments, has compelled central banks worldwide to introduce risk-reduction measures. Following this trend, the South African Reserve Bank took the initiative in April 1994, together with the banking industry, to reform South Africa's system. The problem was approached on an all-inclusive national level, and a strategy was formulated to upgrade our existing system to comply with world-class standards.

The project to implement a new electronic interbank settlement system was identified as the cornerstone of a new national payment-processing infrastructure. The South African Multiple Option Settlement system, introduced on March 9, 1998, was developed over a period of two years as a collaborative venture among the reserve bank, private banking institutions, and the technology suppliers. The system ushered in a new era in electronic payment and settlement in South Africa and will have a major impact on the future development of the national payment system. Furthermore, this system has already enabled the reserve bank to introduce new operational procedures for the execution of monetary policy. Under these arrangements, banks now participate in a daily tendering system, based on repurchase agreements, to obtain funds from, or to repay funds to, the reserve bank.

\section{Reform Sequencing}

In terms of the sequencing of reforms, South Africa has reduced its government's deficit (before borrowing) as a percentage of GDP to 4.1 percent in the $1997 / 98$ fiscal year from 5.5 percent in the previous fiscal year, and is aiming for a further reduction to 3.5 percent in the current fiscal year. We have introduced a system of three-year 
rolling budgets, where we have increased transparency. And we have whittled down South African banks' holdings of government debt to only 7 percent of their assets - a key reason why our banks, unlike banks in other countries, have no problems funding credit.

With South Africa lumped together with other countries in the emerging-markets' class, the management of foreign-currency-denominated debt assumes even greater importance. Spreads over foreign benchmarks can widen dramatically as emerging-market paper comes under pressure. While wider spreads may affect future foreign borrowing costs, they do not immediately affect the country. But purchases of domestic debt by foreigners and the subsequent reversal of these positions can be disruptive to the domestic economy. It is thus imperative, in my view, that the management of debt be very carefully deliberated, and a balance found between foreign liabilities denominated in domestic currency and such liabilities denominated in foreign currency.

As for the legal framework, the reserve bank's main task, as defined in terms of the South African Reserve Bank Act and in the country's constitution, is to defend the value of the rand-that is, to keep inflation as low as possible. This is very much in line with contemporary central banking all over the world. The reserve bank's independence is enshrined in the constitution. Section 32 of the Reserve Bank Act says that the bank must submit a monthly statement of its assets and liabilities and an annual report to parliament. The bank is, therefore, accountable to parliament. The governor of the reserve bank holds regular discussions with the minister of finance and appears before the Parliamentary Standing Committee on Finance from time to time.

On exchange controls, South Africa is in the process of liberalizing its remaining ones gradually, as and when circumstances permit. (In other words, the big-bang approach, advocated by some commentators, has been eschewed in favor of a gradualist approach.) This is part of our push to integrate our financial markets into the global system, in order to benefit from the worldwide flows of investment funds. For a country such as South Africa, where domestic savings are extremely low and the demand for capital investment is extremely high, financial globalization can bring many advantages. A net inflow of foreign investment capital will raise the country's ability to increase its domestic economic growth rate, and to create more jobs for the many unemployed.

Finally, a brief word on exchange rates and transparency. We have found that transparency is the key to pacifying the markets, to con- 
vince the markets that we are moving in the right direction. That is why the reserve bank has published a paper on its forward book and now releases monthly data on its oversold position. I do not want to go into a detailed explanation of the forward book, except to say that we have a long history of providing forward cover, and are phasing out our participation in the forward market as circumstances permit. Indeed, the oversold forward book as of April 30, 1998, represented about 19 percent of the total contracts outstanding in the forward market, down sharply from about 30 percent five years earlier.

In closing, I would just like to underscore the importance of a number of issues that we have been discussing: sound domestic payment systems, accounting standards, legal standards, bank quality, loan quality, on-site inspections-something that we need to do more of - transparency of the financial system, and, as Leonard Tsumba noted, discipline and predictability.

\section{Hiroyuki Hino}

It was a pleasure to read the concise and thoughtful papers of Leonard Tsumba and Piero Ugolini. I would agree with the importance of the challenges that Tsumba discussed, and with the general principles that Ugolini outlined. I believe, however, that there are a few issues that need to be addressed more directly, in light of the recent events in Asia. These are the issues that arose in reviewing possible causes of the crises in Asia-issues that may be relevant for African governments in formulating their own financial policies. I would like to discuss these by posing three questions.

\section{Political Will and Bank Supervision}

How strong should the institutional and technical capacities of bank supervision be before African countries embark on extensive liberalization of their financial systems, as Asian countries have done over the last 10 years or so? In Asia, many observers believe that bank supervision was inadequate when financial sectors were liberalized in Thailand and elsewhere, and that this premature liberalization contributed significantly to the banking system crises. If this is true, most African countries should wait a long time before proceeding on further liberalization, because their supervision capacities are not yet even as good as those that existed in the Asian countries. 
In my view, though, the current banking system crises are more a result of the absence of political will rather than the presence of technical shortcomings. Political will involves the willingness to enforce the existing prudential regulations and to avoid government interventions that create moral hazard. Let me explain.

Banking crises are not new in Asia. Major crises occurred in Malaysia, the Philippines, and Thailand during the 1980s; and in Indonesia, a crisis that began in 1992 continues into 1998. In Malaysia and the Philippines, the health of the banking system has strengthened substantially over the years, thanks to a number of strong measures to enhance bank capital and strengthen prudential oversight. In Indonesia and Thailand, however, little progress has been made. Indonesia began to adopt similar measures in 1986, but delayed enforcement of key provisions and tolerated noncompliance of existing regulations. Thailand took some prudential measures, but they were too little, too late.

In Malaysia and the Philippines, nonperforming loans declined from very high levels in the 1980s to less than 4 percent of total assets by 1996 (see Table 1). Moreover, in Malaysia, banks accumulated a large amount of loan loss reserves, comparable in relation to the amount of nonperforming loans to that of Singapore (see Figure 1). Not surprisingly, therefore, the Bank for International Settlements described Malaysia's banking system as "robust" in its 1996 Annual Report.

By contrast, in Indonesia and Thailand, high-risk bank management continued, or even worsened from 1990-96. The ratio of liquid assets to short-term liabilities fell to extremely low levels (see Figure 1 ), and the reserve coverage of nonperforming loans was very low.

\section{Table 1. Progress in Improving the Soundness of Financial Sectors Varied}

(Nonperforming loans as a percent of total assets)

\begin{tabular}{lcrrc}
\hline & $1980^{\prime}$ s & 1994 & 1995 & 1996 \\
\hline Indonesia & $\ldots$ & 12.0 & 10.4 & 8.8 \\
Malaysia & $30.5^{1}$ & 8.1 & 5.5 & 3.9 \\
Thailand & 15.0 & 7.5 & 7.7 & $\ldots$ \\
Philippines & $19.0^{2}$ & $\ldots$ & 3.6 & 3.6 \\
\hline
\end{tabular}

Sources: Bank for International Settlements, 67th Annual Report (Basel, Switzerland: BIS, June 1997) for Indonesia, Malaysia, and Thailand data; IMF, World Economic Outlook, Interim Assessment, December 1997 (Washington, 1997) for Philippines data.

11988 data.

21986 data. 


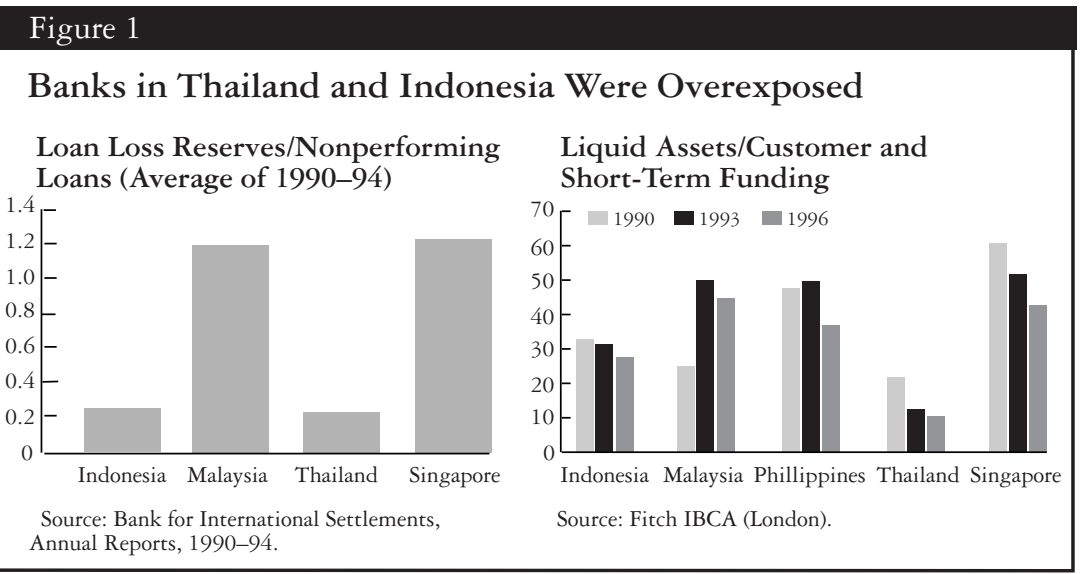

Moreover, Thai finance companies continued to expand their lending at a brisk pace- even after the asset market collapsed and the interest margin (loan rate minus borrowing rate) declined (see Figure 2).

Thus, the difference between Malaysia and the Philippines on the one hand, and Indonesia and Thailand on the other, is the strength of political commitment to restoring banking soundness.

The experience of Kenya also underscores the importance of political commitment. As some of you are aware, Kenya encountered a major banking crisis in 1993, prompting the government to change the management of the central bank, close four major banks that were called "political banks," and seize a number of assets to recover loans that the central bank had extended. Since then, the central bank has been vigilant in detecting problem banks early on and taking corrective measures quickly. A crisis has not recurred, and the Kenyans, I believe, have confidence in their banking system.

So what is the lesson here? I would conclude that if a sufficiently strong political commitment exists, liberalization of the financial system can proceed in most cases while the supervisory capacities are simultaneously being strengthened.

\section{Pacing of Financial Integration}

If African countries succeed in financial sector reforms and attract foreign capital, will they receive substantial long-term productive investment, or primarily short-term "hot" money?

In Thailand, the bulk of inflows over the last few years has been in the form of short-term investment while the volume of foreign 


\section{Figure 2}

Finance Companies in Thailand Expanded Rapidly

Credit to Private Sector

Expands...

... Even as the Stock Market Drops ...

$\ldots$ and the Spread
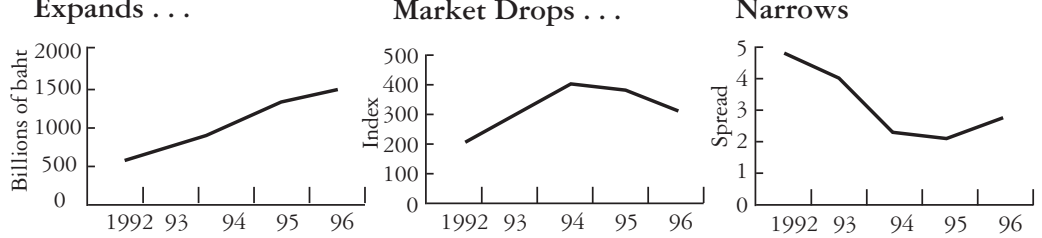

Source: Elie Canetti and Michael Sarel, Thailand-Statistical Appendix, IMF Staff Country Report No. 96/83 (Washington: International Monetary Fund, 1996).

direct investment has declined. In Africa, foreign investors' preference for short-term investment would no doubt be even stronger, given concerns about political and social instability and economic governance. Even for short-term investment, relatively high interest rates would be demanded to accommodate risks that investors perceive. Indeed, Kenyan bankers and accountants estimate that if risk premiums, as well as high operating expenses and intermediation costs, were fully reflected, lending rates of around 25 percent would not be unreasonable.

Should further financial liberalization and integration with the global financial market be delayed in Africa until political risks decline and operating costs are reduced? My answer is "no." Whether the financial market is open or closed to foreign investors, domestic interest rates will need to fully reflect risks and the costs. Otherwise, banks will not be able to set aside adequate provisions against future nonperforming loans, thus enhancing the chances of their eventually running into financial troubles. An alternative would be for banks to set interest rates lower and lend only to very safe borrowers. But if they did this, only a handful of corporations would receive bank loans-which is happening in many African countries-and smaller firms and new entrepreneurs would continue to be denied an opportunity to grow.

So what is the lesson here? It seems to me that most African governments should proceed with financial liberalization and, at the same time, reduce, as soon as possible, the political and social uncertainties, strengthen economic governance, and improve the operational efficiency of the banking systems. This, I believe, is the best way to promote long-term investment, both domestic and foreign, and to harness a sound banking system. 


\section{Exchange Rate and Monetary Policies}

Are international capital flows so volatile that direct controls on capital flows, particularly short-term flows, are required to maintain macroeconomic stability and avoid financial crises?

In Asia, when the economy was booming, foreign investors moved in en masse, and helped generate the asset price bubbles. When the bubbles burst and the situation soured, foreign investors fled again en masse, leaving a severe crisis behind. Many observers in Asia apportion much of the blame to the imperfection or irrationality of international financial markets, and conclude that some form of controls on short-term capital flows are in order.

I would agree that international financial markets are imperfect. In my view, however, excessive capital inflows and the asset price bubbles largely reflected the exchange rate and monetary policies that these countries pursued, in addition to the imprudent lending by the financial institutions. I will explain.

It is now widely accepted that there is a close correlation between asset price inflation and growth of bank credit to the private sector. Indeed, such credit expanded rapidly in the Asian countries during the four-year period preceding the crises (see Table 2).

How did this come about? Central bank purchases of foreign exchange were the main source of liquidity. These purchases reflected exchange market intervention that the central banks undertook to maintain the actual U.S. dollar peg in response to large capital inflows. These purchases were the largest in Thailand, where the exchange rate was most rigidly tied to the U.S. dollar, and the smallest in Malaysia, where the rate was more flexible.

The Philippines and Thailand almost fully sterilized the liquidity impact of exchange market intervention, and kept the growth of reserve money low. Sterilization also kept domestic interest rates high, however, prompting banks to undertake large foreign borrowings. As banks used these borrowings to help fund their lending, both countries ended up with high credit expansion. High domestic interest rates also encouraged nonbank institutions to continue to borrow from abroad.

So what is the lesson here? Had these countries allowed the exchange rate to be more flexible, the associated exchange risks would have worked as an effective deterrent to short-term capital inflows. Extensive sterilization would not have been necessary, and, 
Table 2. Mismanagement of Domestic Liquidity

Contributed to the Crises

(Annual percent averages of the four years, 1993-96, prior to crises)

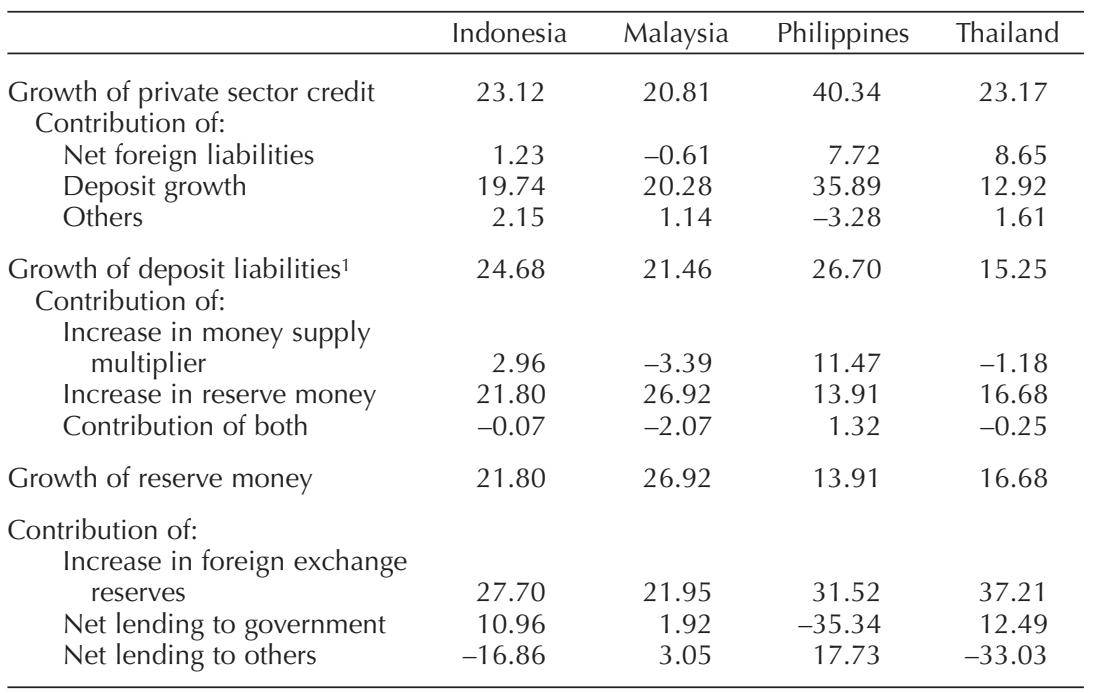

Source: IMF, International Financial Statistics.

${ }^{1}$ Contribution equal to the ratio of the change during the period to the stock of domestic liabilities at the beginning of the period.

instead, monetary policy could have been guided to keep domestic credit expansion in check.

The case for exchange rate flexibility can also be seen by comparing the experiences of Hong Kong and Singapore during this time period. In Hong Kong, where the U.S. dollar peg was maintained through a currency board arrangement, inflation consistently exceeded that of the United States (see Figure 3). In contrast, in Singapore, where flexible management of a basket peg was pursued, inflation was kept at 1-2 percent a year, and Singapore has been largely free of major financial crises.

The recent experience of Kenya also supports the above policy conclusions. It is unfortunate that Micah Cheserem is not here to tell us how Kenya managed both very large capital inflows ( $\$ 500$ million) and a subsequent sudden reversal in the run-up to the elections in 1996. The key, I believe, was the willingness to allow the exchange rate to appreciate in the period of inflows, and to let the rate fall-by as much as a third-when investor confidence was shaken. 


\section{Figure 3}

A Case for More Flexible Exchange Rates

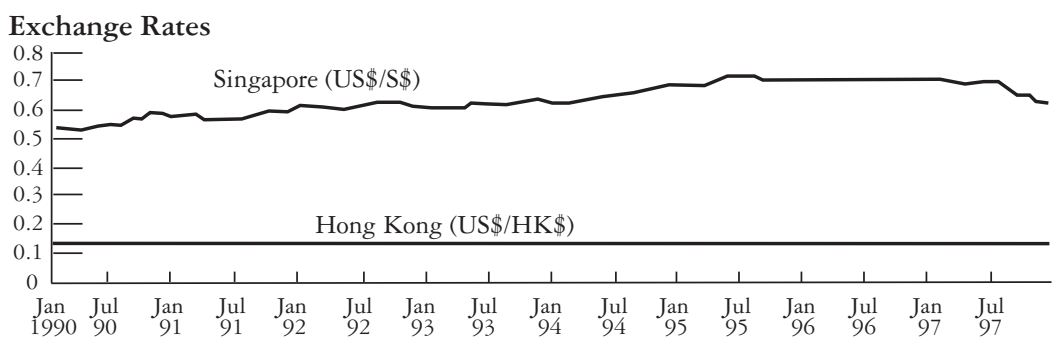

Consumer Price Index

(1990:Q1 = 100)

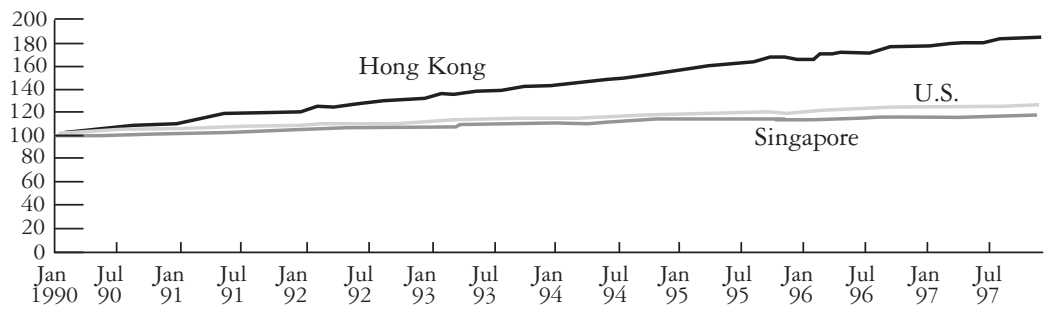

Source: IMF, International Financial Statistics.

\section{Recent Lessons from Asia}

In closing, let me just say that the "new lessons" of the current crises may be the crucial importance of the following:

- effective government-a strong commitment to sustained growth and stability, including the maintenance of an appropriate regulatory framework for the banking industry, as well as the avoidance of moral hazard that weakens the banking system;

- strong institutions-sound banks and an efficient structure for bank supervision; and

- pragmatism-flexible exchange rate management and the readiness to listen to market signals.

In a sense, these lessons are really just an application of the "old lessons" of the Asian miracle to the management of banking systems in our new, globalized financial markets. I am not advocating complete faith in market forces. It is essential to take appropriate safeguards, including steps to lessen the widening 
income disparity between the rich and the poor. Rather, what I am suggesting is the importance for Africa of not reversing or unnecessarily slowing the movement toward financial liberalization, as an overreaction to the Asian crisis. After all, the lessons of the Asian miracle still hold. The recent setbacks notwithstanding, these countries achieved tremendous economic growth over the last three decades, growth that is historically unparalleled. And this growth was in large part thanks to the capital inflows that came about in a liberal policy framework. 


\section{General Discussion}

\section{Financial Sector Reform}

Gray Mgonja of Tanzania opened the discussion by noting that his country's 1995 banking legislation reflected many of the proposals that Piero Ugolini had made for reforming the financial sector, including explicitly making the attainment of low and stable inflation an objective of the Bank of Tanzania, and giving the central bank independence. The governor of the central bank is appointed under a five-year contract-which is renewable-and cannot be removed from office before the contract expires. Moreover, if the governor differs with the minister of finance on monetary policy, the minister is required to publish that difference of opinion in the government newspaper and to report to parliament. So far, the need for such action has not arisen.

Mgonja concurred with Ugolini's suggestion that banking supervision be given to a single authority, preferably the central bank at the initial stage, remarking that when the supervisory role was split between institutions, as had occurred in other countries, problems arose. He also pointed out that Tanzania was harmonizing its banking supervision rules with its East African neighbors, Kenya and Uganda.

Yukio Yoshimura of Japan instead favored separating the banking supervision function from the central bank, because of the risk of conflict of interest between monetary policy management on the one hand and banking supervision and restructuring on the other. He also stressed the importance of ensuring that central banks be independent and that monetary policy not be politicized.

Mansour Cama of Senegal commented that it was difficult to have one overall approach to financial sector reform in Africa because the differences between regions were so great. In West Africa, for example, a banking commission headquartered in Abidjan, as part of the Economic Community of West African States, handles bank- 
ing supervision for the eight member countries. Cama sees the main challenge now for West Africa as one of devising ways to mobilize savings and investment, and to channel savings into investments.

Kwesi Botchwey of Ghana remarked that the formidable challenge of financial intermediation for Africa was not one with which the East Asian economies had to struggle. In Africa, financial sector reform is, disturbingly, too often followed by a shrinking of banks' net worth and, still, very low real savings. He strongly supported the idea of an independent central bank, but even more important for him was that the governor be apolitical and that the central bank be properly capitalized.

Jean-Claude Brou of Côte d'Ivoire agreed with Cama that the main problem now was one of financial intermediation, pointing to an apparent paradox in his country. The private sector frequently complains that it cannot obtain access to needed medium- and longterm credit, yet there is an excessive amount of liquidity with the banks. How could resources be better mobilized? He felt part of the answer might lie in developing capital markets, such as regional stock exchanges where bonds, for example, could also be issued.

Jan Willem Gunning of the University of Oxford tried to turn the discussion on its head by asking: "Even if banking systems in Africa were perfect, would that solve the problem of financial intermediation and bring about high investment rates in Africa?" He submitted that the answer was no, an uncomfortable message, especially for donor circles, where the opposite assumption is held. Gunning based his skepticism on micro-level data for Africa that showed that the effect of increased profitability on investment was very weak in African firms. This means that the binding constraint is not a lack of credit but rather the wariness of private entrepreneurs to invest, in part because of policy credibility problems. The bottom line is that financial sector reform is important, but not a magic solution.

On another aspect of borrowing, Moses Asaga of Ghana noted his country's progress during the 1990s in reducing inflation and interest rates, but asked why it had become so difficult over the past year to further reduce nominal interest rates when inflation was decreasing so rapidly? This theme was picked up by Koichi Hamada of Japan, who noted that something was amiss with economic policy when African countries had inflation rates in the single digits but nominal interest rates still in the double digits.

Hiroyuki Hino of Japan suggested that the problem was really one of economic structure and risk rather than faulty monetary pol- 
icy. For example, a country with 8 percent inflation could end up with 22 percent nominal interest rates, if the real interest rate was 4 percent, the risk premium was 6 percent, and intermediation costs and reserve requirements were 4 percent. What should countries in this predicament do to lower nominal interest rates? He counseled policymakers to let the market determine interest rate levels-as this was necessary to keep the banking system healthy-and instead focus their efforts on reducing risk as quickly as possible.

Piero Ugolini responded to several speakers' comments on banking supervision by reiterating that, ultimately, it did not matter where supervision was located, so long as it was independent. And that included the possibility of an independent unit that was part of the central bank but located in a completely different building. He explained that he favored initially making the unit a part of the central bank, strictly for reasons of efficiency given the size of the financial sector and the lack of qualified staff in Africa to create a new institution. Even in those countries where supervision was outside the central bank, the bank provided support to the supervisory agencies.

James Cross of South Africa closed the discussion by asking the IMF to make it very clear to policymakers during consultations and exchanges what the early warning systems of banking problems are and drawing especially on the IMF's cross-country experiences. 


\title{
6
}

\section{Liberalizing the Trade System}

\author{
Robert Sharer
}

Tncreasing links between international markets is not a new phe1 nomenon. Indeed, growth in the value of international trade in goods and services has significantly exceeded GDP growth almost every year for the past 30 years. In the last decade, however, the growing integration and knowledge of world markets, fostered by major changes in information technology, has led to an explosion of investment flows to developing countries. As the pace of technological change and information flows quickens, and associated costs fall sharply, this globalization of the world economy will only accelerate.

How can Africa reap the benefits of globalization and foster an environment conducive to private investment? This paper looks at the prominent role that liberalization of the trade regime can play, focusing on the challenges facing Africa.

\section{Challenges of Globalization in Africa}

The opportunities and potential gains that globalization presents for Africa are apparent from a comparison of past trends (see Figure 1).

- From 1975 to 1996, the average annual export growth for Africa was 4.8 percent, or about one-half the rate for industrial countries and for non-African developing countries, and only about 


\section{Figure 1}

Africa Underperforms in Trade ...

Annual Growth in Goods and Services Trade, 1975-96

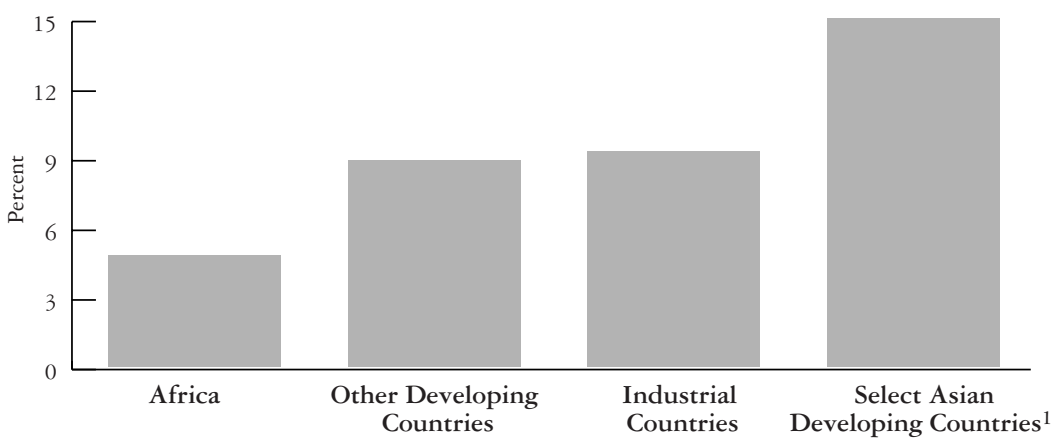

$\ldots$ and Investment

Net Private Capital Flows to Developing Countries

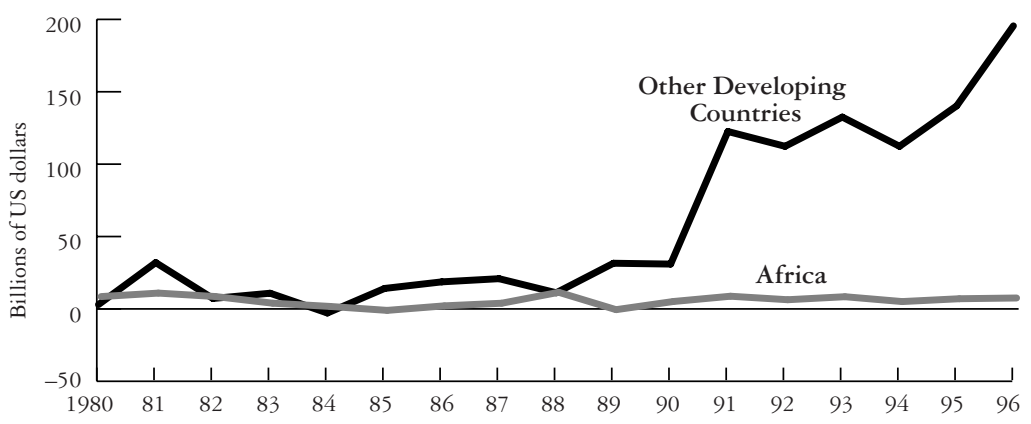

Source: IMF, World Economic Outlook.

${ }^{1}$ China, Hong Kong SAR, Indonesia, Korea, Malaysia, Singapore, Taiwan, and Thailand.

a third of the rate for the export-oriented economies in Asia. As a result, Africa's share of world trade fell from 4.6 percent to below 2.0 percent during this time period.

- Foreign investment shows an even more dramatic picture. Net private capital flows to all developing countries increased to $\$ 23$ billion in 1988 from $\$ 12$ billion in 1980, and then rose sharply to $\$ 207$ billion in 1996 . But while net private capital flows to Africa grew to $\$ 12$ billion in 1988 from $\$ 9$ billion in 1980 , they stagnated thereafter. In other words, net private capital flows to Africa, as a percent of inflows into all developing 
countries, fell to below 10 percent by 1996 from about 50 percent in the mid-1980s.

This relative decline is the counterpart of dynamic performance elsewhere, notably, of Asian economies_although the recent financial crisis in Asia has meant a setback for all emerging market countries-with foreign investment in Africa falling sharply. This setback may well prove to be temporary. Nevertheless, the timing is now propitious for Africa to capitalize on the trend toward globalization. This means dramatically speeding up the pace of trade liberalization, if Africa hopes to benefit from the increasing global pattern of production and trade, by improving both incentives and the investment climate.

Why is trade liberalization so important? It improves the efficiency of resource allocation, enhances economic growth, and improves transparency and governance. As for the benefits for economic efficiency and comparative advantage, these are well known and need not be elaborated on further. Overall, there is a large, and growing body of empirical research that provides ample evidence that liberalization of the trade system provides an important stimulus to exports and economic growth. ${ }^{1}$ Indeed, there is no case of a highly restrictive trade regime being associated with sustained strong economic performance. Trade policy does not work in a vacuum, but as a complement to appropriate macroeconomic and other structural policies. Lowering trade barriers reduces the cost of imported inputs and improves access to them, reduces anti-export bias, and facilitates the transfer of knowledge and foreign technology. Trade reform is thus a critical component of moving to a virtuous cycle of export-led growth.

What is a reasonable level of openness? In principle, the objective of trade reform should be free trade, and the faster it is imple-

\footnotetext{
${ }^{1}$ For evidence on the links between open trade regimes and economic growth, see International Monetary Fund, World Economic Outlook, May 1993: A Survey by the Staff of the International Monetary Fund, World Economic and Financial Surveys (Washington); International Monetary Fund, World Economic Outlook, May 1997: A Survey by the Staff of the International Monetary Fund, World Economic and Financial Surveys (Washington); Robert Sharer and others, Trade Liberalization in IMF-Supported Programs, World Economic and Financial Surveys (Washington: International Monetary Fund, 1998); World Bank, The East Asian Miracle: Economic Growth and Public Policy (New York: Oxford University Press, 1993).
} 
mented the faster the benefits are attained. In practice, however, very rapid movement from a restrictive to a completely open regime is difficult to achieve. Thus, the goal should be early movement to a trade regime that minimizes distortions and enhances transparency. This means moving to relatively low and broadly uniform tariffs, and the progressive elimination of nontariff barriers to the flow of goods, services, and investments.

Establishing a broadly uniform tariff structure should be complemented by consolidating all other duties and charges into the basic tariff structure and eliminating exemptions, particularly discretionary exemptions, for particular individuals or groups. Dismantling nontariff barriers should include removal of measures that restrict trade, either through quantitative restrictions or by allowing administrative discretion so as to restrain trade. These reforms improve transparency, predictability, and simplicity of the trade regime, thereby promoting good governance.

\section{How Africa Compares}

How do African trade regimes compare with other regions? One way to judge this is by looking at an index of overall trade restrictiveness that the IMF developed as part of a recent study of trade liberalization in IMF-supported programs during the $1990 \mathrm{~s}^{2}$ (see Figure 2). The index provides a 10-point scale that summarizes the aggregate restrictiveness of key elements of the trade regime, namely tariffs and nontariff barriers, ranging from 10 (most restrictive) to 1 (completely open). For analytical simplicity, trade regimes can be classified as open (1-4 rating), moderate (5-7 rating), or restrictive (8-10 rating).

The study showed that during the 1990s, many African countries have liberalized their trade regimes, often significantly, in the context of structural adjustment programs. At the outset of the programs in the early 1990s, trade restrictiveness in Africa, however, was generally high. About 70 percent of these countries had trade regimes classified as restrictive-and most of these were highly restrictive, classified as 10 on the index. None of the regimes were classified as open. The reform programs usually targeted a quantifiable reduc-

\footnotetext{
${ }^{2}$ See Sharer and others (1998).
} 


\section{Figure 2}

Africa Remains Restrictive...

... as Measured by a Trade Restrictiveness Index ${ }^{1}$
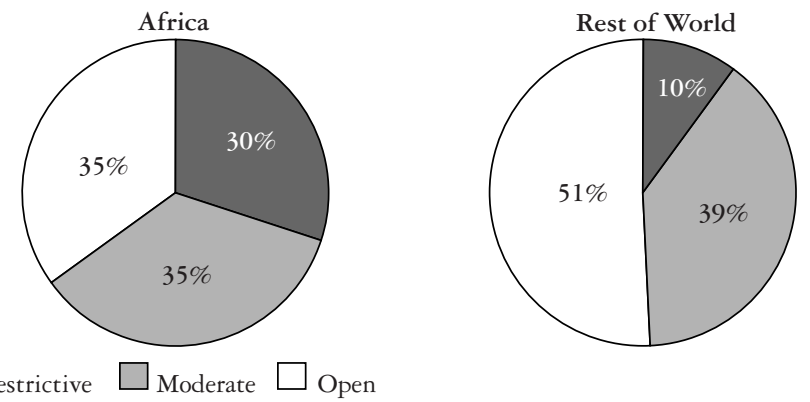

... as Measured by Average Import Tariff Rates 1,2

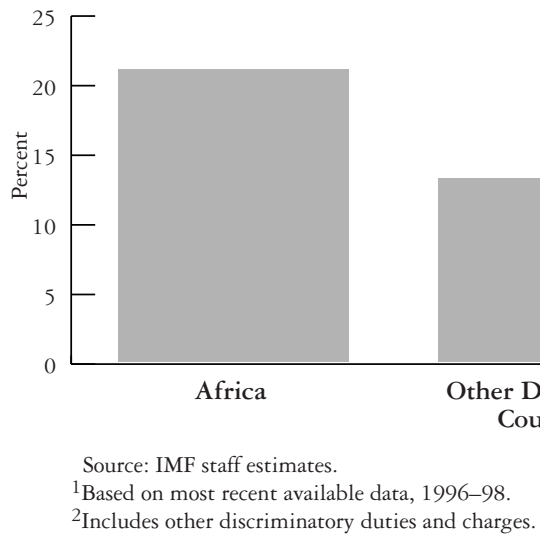

tion in overall trade restrictiveness. In fact, the average degree of liberalization targeted was about the same in the African programs as in all the IMF-supported programs and in the great majority of cases the targets were achieved. Thus, significant trade liberalization did occur but because African countries started from a more restrictive position, most trade regimes remained restrictive or moderate even after the reform programs.

The analysis shows a similar pattern when it is extended to the whole of Africa, rather than to just those countries with mediumterm IMF-supported programs, and updated with the most recently 
available data. We see that nontariff barriers continue to be widespread, tariffs remain relatively high, and that, compared with the rest of the world, a significantly higher proportion of Africa's trade regimes remain restrictive (see Figure 2). Moreover, Africa's average tariffs are above 20 percent, which is higher than an average 13 percent for non-African developing countries, and substantially higher than the average 6 percent for industrial countries. It is the last group that dominates world trade. These findings underscore the need for most African countries to target significant further trade liberalization to enhance competitiveness.

\section{Moving Toward an Open Regime}

Of course, some difficult issues arise when it comes to implementing trade liberalization. First, trade reform, like any important economic adjustment, necessarily involves the reallocation of resources. As trade barriers are lowered, some formerly protected sectors are exposed to competition. Workers lose their jobs and must search for new employment. But there are policies to mitigate these inevitable social costs-generally referred to under the rubric of social safety nets. These include severance payments, training and relocation programs, and measures to develop alternative employment opportunities.

Such programs are not only right, they also help to create the needed public support to make the reform package sustainable. The design, implementation, and funding of social safety nets presents difficulties, but this should not be used to substantially delay trade reforms, as it also delays the benefits, in essence "throwing out the baby with the bath water." Trade reform programs need to be credibly ambitious in their scope and timing.

A second difficulty arises because trade taxes may be an important source of revenue, particularly in low-income countries. But here, too, the difficulty should not significantly delay reform. The answer lies in focusing first on the tariffication of nontariff barriers and the removal of exemptions, as both of these reforms act to increase tax revenue. Moreover, any loss of revenue from tariff reduction should be offset through introducing broader-based taxes such as a value-added tax. An important element of program design, however is that, where necessary, trade reform should be preceded by technical assistance to improve the efficiency of tax 
administration and increase enforcement. Indeed, an IMF study on trade reform showed that when programs were successfully implemented, revenue performance was not weakened. ${ }^{3}$

In an ideal world, trade reform should be complete and immediate, but in the real world, choices among competing objectives have to be made. How fast can countries reform? The experiences of some "good practice" countries sheds light on what is feasible (see Figure 3). These countries-Chile, Colombia, and New Zealandprogressively accelerated their growth rate and trade performance in a sustained manner, in the context of implementing broad-based economic reforms. This included moving from restrictive (index categories 8-10) to open (index categories 1-4) trade regimes over periods of about seven years. Although these countries are star performers, this time frame is consistent with the experience of many other countries. Of course, beginning with a less than highly restrictive regime, a country should be able to move to an open regime more rapidly.

A number of African countries have also made impressive efforts to liberalize. In 1985, for example, Ghana and Uganda had high tariffs, pervasive nontariff barriers, distorted exchange rate regimes, and other restrictions. Overall, their trade regimes were highly restrictive (see Figure 3). But starting in the mid-1980s, both countries undertook ambitious policy reforms, including trade reforms, initially focusing appropriately on dismantling nontariff barriers and subsequently lowering tariffs. This opened them up to much needed external competition. As a result, the overall restrictiveness of their trade regimes has moved into the moderate range, and further planned reforms will move them into the open category. The beneficial impact of the reforms are clearly evident in the greatly enhanced economic performance of these countries.

\section{The Investment Climate}

So far, we have focused on average import tariffs and the coverage of nontariff barriers. Other elements of the trade regime are also important, however, including trade-related exemptions, tariff

${ }^{3}$ The sharply improved economic performance of these countries is detailed in Sharer and others (1998). 


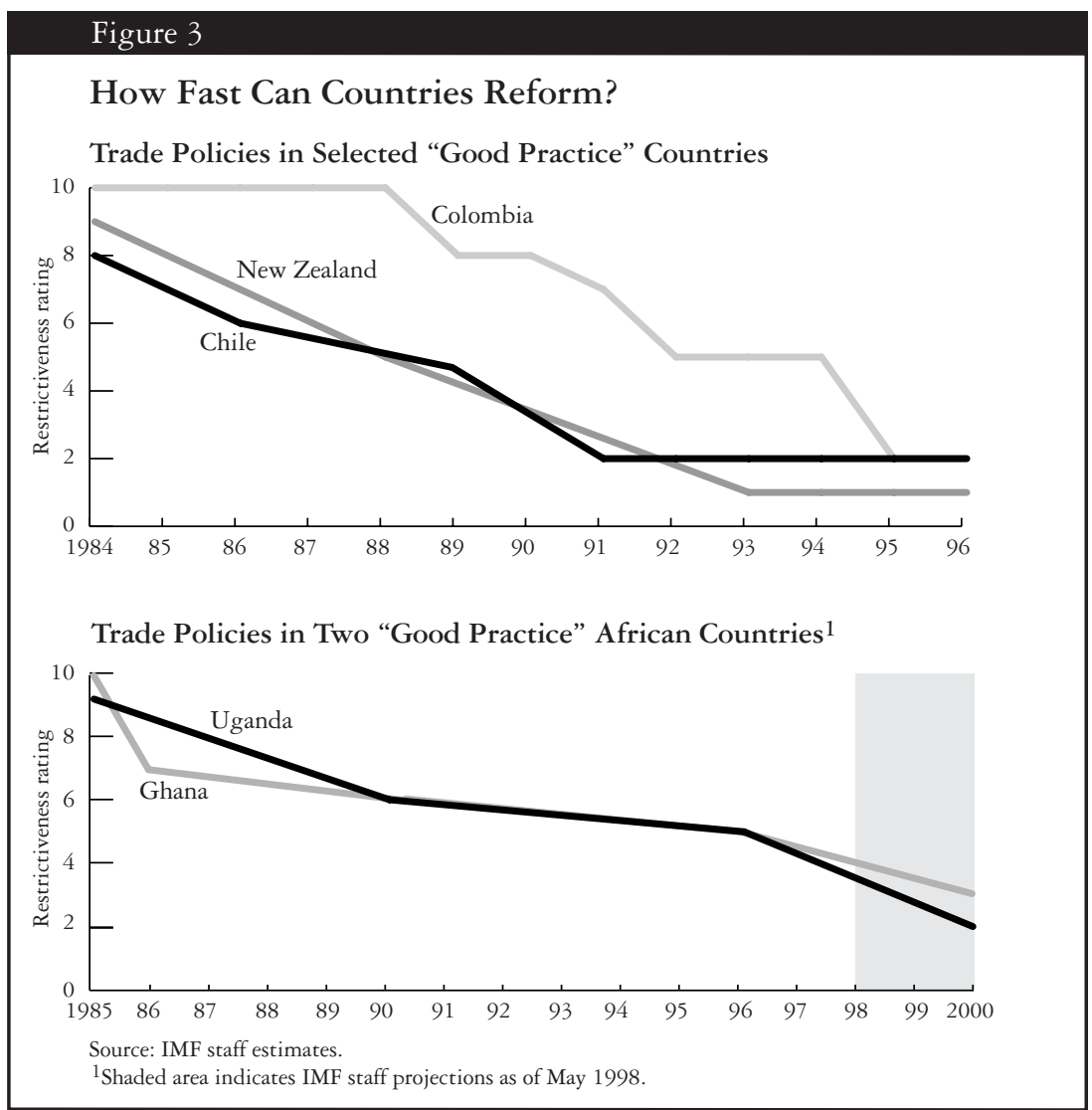

dispersion and variability, and the complexity of the system and its administration. These other elements can detract from the efficiency of resource allocation and thus affect the investment climate directly through the impact on economic efficiency. They may also have a substantial effect on the investment climate by reducing transparency and impairing governance.

Owing to their highly disaggregated nature, trade policies are particularly suited to the redirection of resources to narrow interest groups. Transparency is an issue because those adversely affected by trade policy are often affected indirectly and may not be aware of the effect. Complex and discretionary trade policy regimes not only create opportunities for corruption-particularly in the case of discretionary licensing and tariff exemptions-but also lead to legal but inefficient and nontransparent rent-seeking. 


\section{Figure 4}

East Asia Has Become Quite Open

Trade Policies in Selected East Asian Countries

Advanced Economies

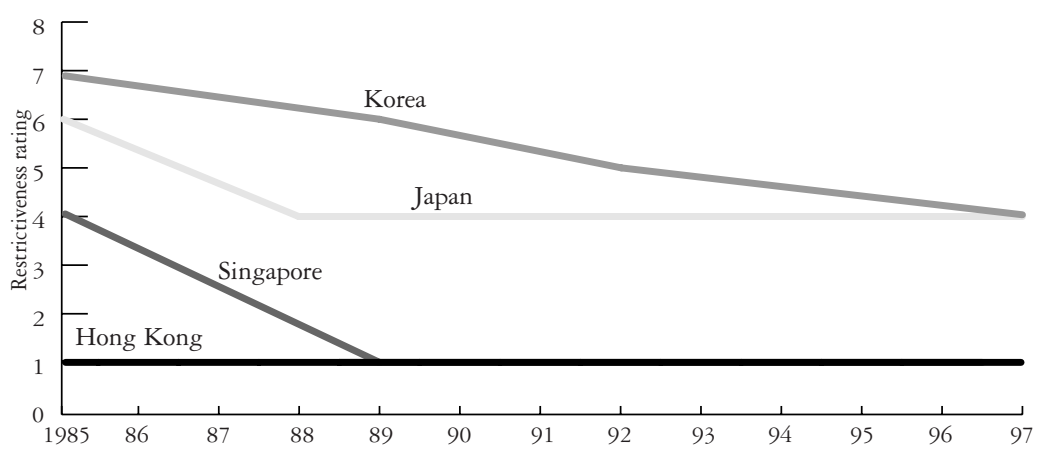

Four ASEAN Economies

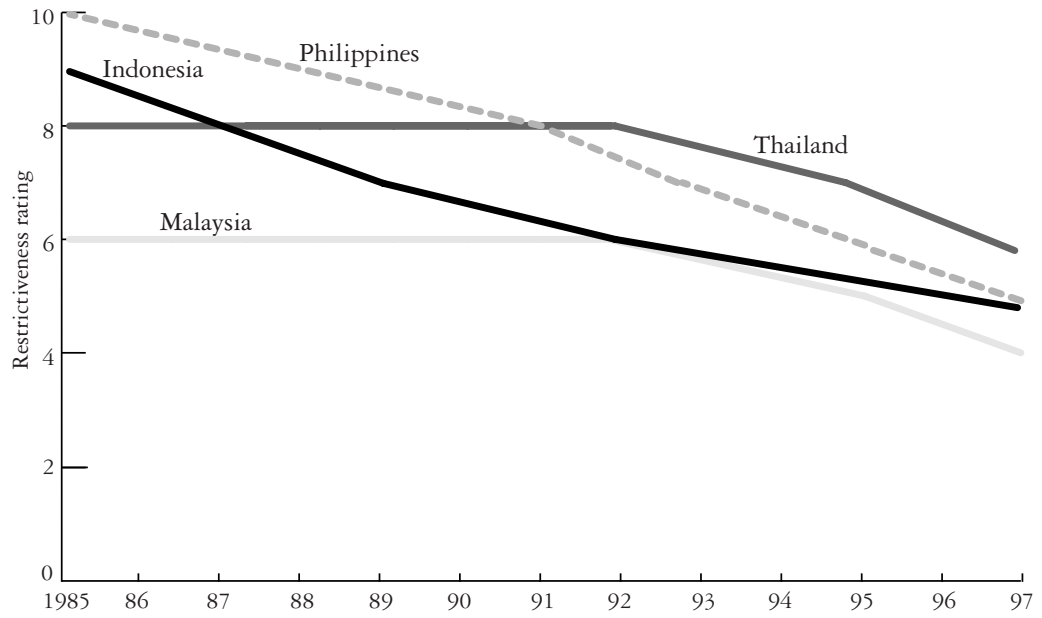

Source: IMF staff estimates.

The first session of this seminar discussed a variety of features of the overall regulatory regime that are critical to improving the investment climate including foreign investment restrictions, the legal system, the financial system, and infrastructure development. A simple, transparent, and predictable trade regime plays a similar role in fostering a healthy climate for foreign and domestic investment, because it eliminates discretionary actions, is fair to all, and reduces opportunities for rent-seeking behavior that discourages many in- 


\section{Figure 5}

\section{Higher Exports Help Overall Growth}

Real GDP and Export Growth for Selected East Asian Countries, 1975-95

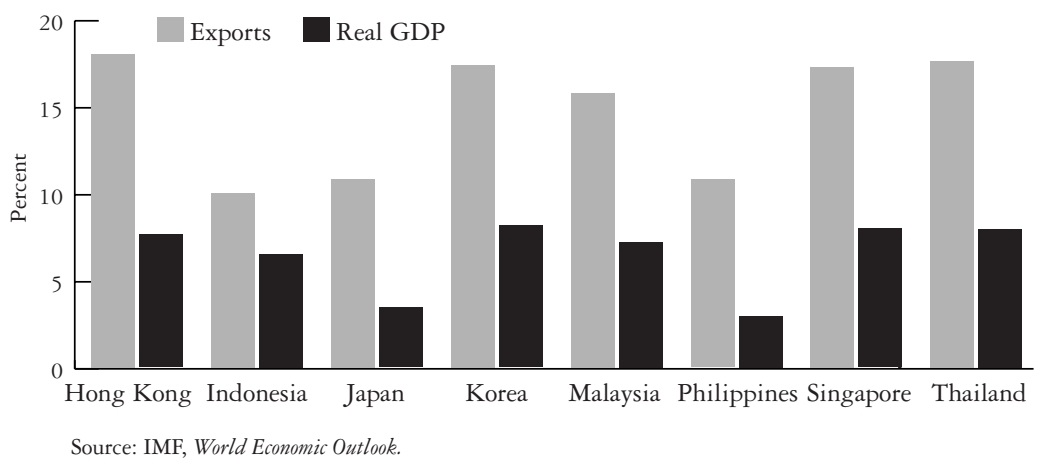

vestors. Furthermore, an open and predictable trade regime not only creates a level playing field, but also signals to potential investors that the government is serious about creating an economic climate that is market-oriented and favors productive activity. Indeed, broad-based and comprehensive trade reforms, preferably preannounced, can contribute importantly to improved governance.

\section{Lessons from Asia}

Can Africa draw any specific lessons from the trade reform experiences of East Asia? Certainly, trade reform has moved these economies, often starting from restrictive trade regimes, in a clear direction of openness approaching or matching those attained by the good practice countries cited above (see Figure 4 on page 91). Hong Kong and Singapore have maintained, for many years, completely open trade regimes. Other countries in the region have levels of openness broadly approaching full openness, although maintaining moderate nontariff barriers for some sectors. Underpinned by a strongly supportive macroeconomic climate, these trade and other structural reforms have contributed to impressive economic growth and export performances (see Figure 5).

But one lesson that should not be overlooked is that although these countries had liberalized trade substantially in terms of lower 
tariffs and moderately in terms of nontariff barriers, this appears to have masked a high degree of administrative discretion in some areas. While these transparency and governance issues were indeed known prior to the crisis, the actual extent of problems, particularly in the financial and corporate sectors, emerged only following the onset of the crisis.

Even so, these weaknesses should not detract attention from the policy framework underlying East Asia's tremendous success over the last few decades. Africa now needs to emulate East Asia's record on trade liberalization, if it hopes to adjust and reap the benefits from globalization. 


\section{Comments}

\section{Hirohisa Kohama}

My background is that of a general development economist, not necessarily an expert on sub-Saharan African economies. So I would like to focus on several points that Robert Sharer made that had to do with the process of structural change and structural adjustment.

At the beginning of his paper, Robert Sharer mentions information technology. I realize that information technology is a very powerful technological advance and a very powerful policy measure for accelerating growth in every economy. Indeed, the World Bank would like to be a knowledge bank. But my first point is that we should be very careful to keep in mind the equity and income distribution aspect among countries and within a country-that is, the dangerous aspects of furthering inequality by utilizing information technology.

My second point is rather controversial-I would like to draw a comparison between the growth potentials of Asian and African countries. Over the past few years, Africa's growth performance has been higher than that of East Asia, but I think that over the medium and long term, East Asia's potential growth is higher than that of Africa. In other words, it is important to understand the performance of policy reforms in African countries. Here, I am sure that some participants will have a different view of the growth potential of the two areas.

The third point centers on foreign direct investment. In his presentation, Sharer highlighted the sharp increase in net private capital flows to developing countries since the end of the 1980s. Ten or 15 years ago, net foreign capital inflows to African and Asian countries were at about the same level. But since the mid-1980s, private capital inflows, especially foreign direct investment, to East Asian countries, have increased sharply, unlike in Africa. Indeed, this is one of the most important components to understanding the high growth that these Asian countries eventually attained. Right now, 
however, in the face of the economic crisis, private investors are waiting to see if East Asia's growth potential will recover or not.

I am aware that the rate of return of foreign direct investment in Africa is not that low compared with the rate of return in East Asia. But what is needed to spur a real increase in foreign direct investment is political stability and investor confidence in the region. Such credibility or confidence of private investors is vital, not only for Africa, but for East Asia as well.

The next point relates to Sharer's comment on the design and the pace of sequencing of policy reforms in Africa. I am very happy that IMF economists are pointing out the importance of this topic. In the past, say, 10 years ago, I do not think that there was any concept of sequencing in IMF economics. I do not know if I am correct or not, but from the perspective of an outside economist, IMF economists seemed very naive.

My last point is on the "good practice" countries. Sharer highlighted two country cases, Uganda and Ghana. I realize that many IMF and World Bank documents say that Ghana is a very successful country in terms of reforms. I also realize that among sub-Saharan African countries, Ghana may be one of the most successful countries since the mid-1980s. But I am afraid that private investment in Ghana is not very active. I am also afraid that in Africa, even in the "good practice" countries, we do not see private investment tending to increase sharply. By contrast, the dynamism of private investment in East Asian countries is impressive. We observe sharp increases of private investment in many of these countries and this matters because private initiative is essential for accelerating economic growth.

Now let us move to the rent-seeking versus profit-seeking behavior of private companies. Sharer pointed out the inefficiency of rentseeking behavior. I completely agree. But how do you change the mentality of private companies to seek profits instead of rents? A competitive environment is critical for accelerating economic growth.

Take the example of Japan in the late 1950s and 1960s. In an effort to catch up, the Japanese government protected private manufacturing industries. But even in the protected market-including in the oligopolistic industries such as the petrochemical, passenger car, and steel industries - there was fierce competition among the private companies. Their behavior was not rent-seeking, but profit-seeking. So why, in the 1950s and 1960s, in a protected market, did Japanese manufacturers compete fiercely with each other? Let me give you one anecdote on trade liberalization. 
In June 1960, the Japanese government announced a comprehensive schedule of trade liberalizations-specifying a set pace for various categories-and did not diverge from this announced schedule. In other words, it is very important to prepare for future competition with foreign companies. Japanese manufacturing industries are now very competitive, but in the 1950s, they knew that they were very weak and that it was very difficult to compete with manufacturing companies in the United States, Germany, the United Kingdom, France, and some other developed countries. The Japanese people-not only manufacturers but also politicians, technocrats, academicians, and journalists-all wanted to become a rich country, an advanced country, and in this connection, some wanted to join the Organization for Economic Cooperation and Development (OECD). Japan did join the OECD in 1964, but in order to do so, we had to liberalize trade and foreign direct investment. Therefore, the potential pressure of competition with foreign companies is a key element toward understanding the fierce competition among Japanese manufacturers even in the protected market. One other fact that we should not lose sight of is that the most important point of industrial policy is not the subsidies, or the directed credit, or the tax exemptions, but the design of policies in close communication with the private sector. And that implies a key role for government in ensuring a competitive economic environment.

In this connection, I expect some African countries would like to become so-called newly industrialized countries. Thirty to 35 years ago, the income levels of Korea and some other Asian countries were lower than that of some African countries, but they made every effort to enhance productivity-both labor and total factor productivity - to prepare for the future competition with foreign countries. Such a way of thinking is vital if Africa hopes to realize its growth potential.

\section{Ibrahima Makanguilé}

The remarks made so far in this seminar are important for all African countries-and especially for West Africa's private sector. But there are a number of problems with the approach being adopted, whether it be that of the academic, the decision maker, the partner in development, or the entrepreneur in the private sector. 
If we take the case of trade liberalization in West Africa, for example, and compare it with what has been done in other parts of the world, we quickly realize that a country's level of development plays a critical role in its policy choices. Indeed, trade liberalization or market liberalization typically corresponds to a given level of economic development in the country seeking to liberalize.

So we must ask ourselves what is the level of economic development that West Africa has currently reached, as it is at this level that Africa must weigh whether or not to pursue economic liberalization. While the rate of growth has been encouraging in countries like Ghana and a few others in the West African CFA-franc zone, growth has largely reflected the automatic effects of the 1994 devaluation.

Indeed, Mali's case is a good example, with a growth rate of about 6 percent that is attributable chiefly to the key role of cotton in our economy. Indeed, not only is more than 98 percent of the cotton produced in Mali exported, and therefore sold for foreign exchange, but the Compagnie Malienne des Textiles is also the largest taxpayer in the country. This high-profile role of the Compagnie Malienne des Textiles in Mali's public finances is dependant largely on the foreign currency price of cotton, as well as on an adequate rainfall, which is an act of God-for without rain, there is no cotton. It is, therefore, important for countries such as Mali, Chad, and Senegal to weigh what trade liberalization would really contribute to their economic development.

According to the private sector, the sustainable development of our countries is linked not only to the soundness of our economies but also to the role of the private sector. So if we would like the private sector to be a driving force in our economies, we have to define the strategy to be followed and thus the priority decisions. It strikes me that, in light of our increasingly globalized world, a key question for West Africa should be whether further trade liberalization-and please note that our trade relations are among the most liberal-should be given a high priority? This needs to be asked since despite all the development that has taken place so far, the well-being of our people has not kept pace.

In an effort to answer that question, I would like to suggest that trade and business should be liberalized under the aegis of a strong state. A strong state is one that knows how to enforce the laws passed by its Parliament, a democratic state in which personal freedoms are exercised entirely without bias, and one in which the administration 
is efficient not only in its traditional tasks of planning, promoting, and monitoring but also in its enforcement of the law. In most of our states today, the administration is weak, inefficient, and corrupt, with ridiculously low wages and a barely controlled rate of inflation.

Ultimately, we will need to create a modern development administration that is bold, has a strategic action plan, and is capable of both designing and executing all of the current programs that are now going unmanaged. A development administration is one that is actually aware that it provides services. After all, what is it that treasury collectors, government physicians, police officers, or even magistrates do? They render public services that citizens remunerate through the payment of taxes.

As for trade liberalization, that is now unavoidable in West Africa. Indeed, the Economic Community of West African States (ECOWAS) is a good example of subregional cooperation that holds the potential to help our economies strengthen each other, drawing on the size of the market that each member country represents. But the reality is that beyond the political discourse, the signed agreements are difficult to implement because the member states lack the political will needed to move toward a true trade liberalization zone.

The West African Economic and Monetary Union, a subregional grouping within the Economic Community of West African States, is also finding it difficult to get over the last hurdle in the liberalization of its zone-despite a common currency, a common central bank, and common institutions. Indeed, there are still tariff and nontariff barriers at several points along most of the common borders between the states.

Solutions must also be found for the problem of integrating subregional free trade areas within the context of regional or zonal adjustment programs, unlike what is currently seen in the programs of individual countries, with performance indicators such as customs services or tax collection.

Taking our countries individually, if Côte d'Ivoire is doing a little better than the others it is primarily because of its good policy on infrastructure. Indeed, it is essential to understand that development is linked to both human and physical infrastructures. The development of these infrastructures is a task that, up until a few years ago, still depended solely on the government. But there can be no productive private sector in an environment without good infrastructures, as Vina-Seeburn Dabeesingh reminded us earlier. 
To sum up my remarks, we should focus on three priority areas:

- There needs to be human and physical capacity building, aimed at greater efficiency in the public and private sectors. In the past, cheap labor used to be a justification for investment choice but this proved wrong, insofar as the workforce was unskilled, untrained, and thus incapable of getting the work done.

- The private sector needs to be better organized to play its role in lobbying and participating in public affairs. It should not wait for the administration to do everything for it. The West African Enterprise Network has been active in the West African region for the past four years, making concrete proposals, organizing meetings with the authorities, and holding training seminars for parliamentarians.

- Bilateral and multilateral development institutions should include civil society in the search for solutions to development problems. This seminar should serve as an example in this regard, because all participants in the development of our countries are here today.

Lastly, I would like to thank the Ministry of Finance of Japan and the IMF for having afforded the private sector an opportunity to share its views. 


\section{General Discussion}

\section{Trade Reform and Africa's Image}

Tomáz Salomão of Mozambique set the tone by asking what Africa needed to do to change its image so that it could tap into the huge pool of foreign capital. Yes, political stability was vital, but so was a new world attitude. No longer should Africa be seen as a continent of war, poverty, disease, coup d'etats, corruption, and lack of transparency. There were many good examples in Africa that should be capitalized upon, and good stories to be told. The IMF, World Bank, and other international institutions need to work with Africa to alter its image. If not, 5 or 10 years from now, little would have changed. He also asked for support in helping to explain to the general populace that trade liberalization is more than just a way to promote development, it is also a way to improve the quality of life.

Moses Asaga of Ghana seconded Salomão's views, noting that Ghana had taken the same trade liberalization steps as Korea, yet investment was still not forthcoming-leading to criticisms in parliament of the whole liberalization effort. He urged the World Bank and the IMF to come up with economic programs that were based on best practices in Africa, not in Asia or the European Union.

Hiroyuki Hino of Japan, however, doubted that image was the problem. Speaking as "an Afro-optimist and an Afro-realist," he felt that many investors were opting not to invest in Africa because of the difficulties of doing business there. Problems with petrol and electricity supplies in some countries offset the relatively low labor costs. Thus, trade reform should be viewed realistically-it is a necessary but not a sufficient condition for attracting foreign direct investment.

Kwesi Botchwey of Ghana took strong issue with Hino's interpretation, insisting that Africa's image problem was very real. His own studies at Harvard had shown a high level of ignorance among businesspeople the world over about progress made in 
Africa in the 1990s. In addition, there was a "neighborhood effect," where even if a small country did everything right, it suffered if a neighboring large country was in trouble. Even on risk ratings, professional raters admitted that African countries received, on the margin, a lower rating than they deserved.

Jean-Claude Brou of Côte d'Ivoire injected his own note of reality. Trade reform is just one of many elements needed to attract foreign investment, along with political stability. He was hopeful that regional integration would help greatly by harmonizing tax, monetary, and legal policies, thereby creating a more stable environment for investors. For him, the creation of the Economic Union brings to the fore the key problem of the pace of implementation, especially for the landlocked countries. As a result of the change in custom duties, policymakers in these countries have to cope with a short-term risk of a drop in revenue because import duties tend to form a large part of the government's revenue. Here, the IMF and World Bank could help with technical and financial support to assure policymakers that the transition would be orderly, as there is no question that over the medium term, trade reform and integration would bring enormous benefits.

René Mbappou of Cameroon, who also characterized himself as an optimist, noted that many countries in Central and West Africa have made a good deal of progress on the trade front. For them, the next hurdle was moving beyond the level of subregional integration. He also called on the IMF to be more understanding and humble. Trade liberalization measures were difficult to adopt, requiring time and assistance-not just in terms of human resources but also in terms of financial resources. Indeed, more financial help was indispensable in helping countries to open up.

Mansour Cama of Senegal noted that attitudes in the private sector toward trade reform were divided. One group of entrepreneurs, the export-led companies, tended to be positive, while the other group of entrepreneurs, the import-substitution companies, tended to be negative. He wondered whether trade reform was really essential, asking if the Asian tigers-which had had protected economies for a long time-relied on trade liberalization for their takeoff, or only pursued it after their takeoff?

Peter Freeman of the United Kingdom shared concerns raised by Asaga and Salomão, emphasizing that trade reform must be viewed in a broader context, as just part of a strategy to boost investment and growth and reduce poverty. He suggested that landlocked countries-given the extra transport costs and time factor- 
stood to gain less from trade reform than sea-bordering countries. He also felt that South Africa's economic progress held the key for Southern and Central African countries, as did Nigeria's for West Africa.

Jan Willem Gunning of the University of Oxford countered the skeptics by making a strong case for trade reform. He said studies showed that trade restrictions in Africa were actually more damaging than when countries elsewhere adopted the same restrictionsthe reason being that many African economies were very, very small. Picking up on questions as to what more Africa could do, at least for those who had liberalized, he contended that liberalization still had not gone far enough. Although many countries had lowered their tariffs, they had not bound these with the World Trade Organization. This meant that while applied rates were low, ceiling rates were still high, sending investors the message that governments wanted to maintain the freedom to alter their current fairly liberal policies.

In responding to comments and questions, Robert Sharer of the IMF disagreed with Hirohisa Kohama's comment that over the medium and long terms Africa's growth potential was lower than that of East Asia, suggesting that levels and rates of change were being confused. Clearly, investment in Africa was going to remain below the levels of Asia for a long time, but given Africa's low base, there was tremendous scope for increasing the rate of growth of investment. In addition, there was enormous scope for using existing resources more efficiently.

Sharer also took issue with Freeman's analysis that trade reform might be less significant for landlocked countries. In fact, quite the opposite was true. Landlocked countries with strong trade and price controls sometimes ended up putting resources in low-value agricultural crops in distant regions where there was no transport. In other words, it was vital to take comparative advantage and relative costs-particularly of transport-into account when allocating resources.

In response to Cama's question on the importance of trade reform for the "Asian tigers," Sharer said trade liberalization was launched before the economic takeoff-not after-and yes, it did play a role in the East Asian miracle. He also agreed with Botchwey, Salomão, and others on the image question. Many African countries were doing much better than in the past, yet the information was not getting out to the rest of the world. 
In closing, Co-Chairman Jack Boorman seconded these concerns about image, emphasizing that all development parties should do a lot more to spread the word about the success stories in Africa. And he closed with a question of his own: "Is there a minimum regional dimension, or dynamism, that needs to be in place to make an area attractive, or is Africa still paying the price of its poor image?" 
This page intentionally left blank

CInternational Monetary Fund. Not for Redistribution 


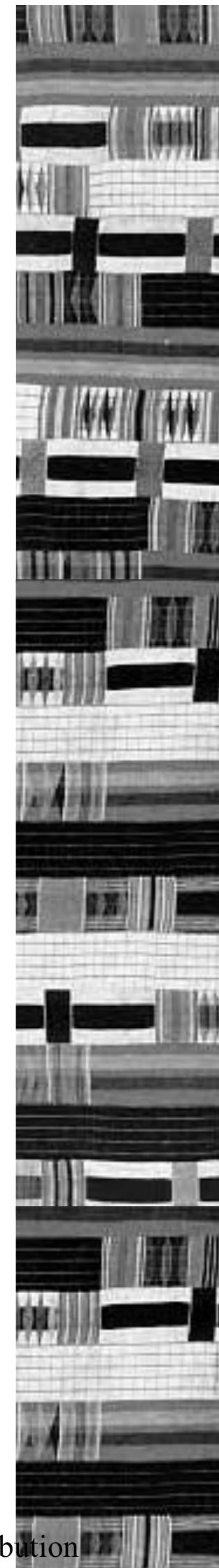


This page intentionally left blank

CInternational Monetary Fund. Not for Redistribution 


\title{
7
}

\section{Better Public Sector Resource Management: Capacity Building and Good Governance}

Emmanuel Tumusiime Mutebile

\begin{abstract}
Overnments in Africa have embarked on a comprehensive pro-
gram supported by the World Bank called Partnership for Capacity Building in Africa. Launched in October 1996, it is aimed at helping African countries undertake national capacity assessments, formulate national capacity building strategies, establish a trust fund for capacity building in Africa, and ensure that the World Bank and other development partners incorporate capacity building into their operational practices and procedures.

What is capacity building? Capacity building is a broad concept encompassing any activity whose output is the increased ability to carry out specified functions more effectively. Capacity building includes training and the development of human resources, as well as improvements in systems and institutional structures.
\end{abstract}

\section{Uganda's Capacity Building Plan}

In Uganda, a systematic approach to capacity building was developed long before the African capacity building partnership was created. A strategy and program of action were developed between 1991 and 1993 through consultations with all the major stakehold- 
ers, including government ministries, institutions of higher learning, technical education institutes, private sector organizations-such as the Uganda Manufacturers Association and the Uganda Bankers Association-accountants, members of the various consulting professions, and the donor community. These consultations culminated in Uganda's Capacity Building Plan, which was published in 1994.

The objective of the plan was to build Ugandan ownership of the capacity building process, to identify the areas that needed priority attention, to develop an overall institutional framework to implement the plan, and to guide donors in their financial and technical assistance contributions. The plan recognized that Uganda's longterm development depended on the capacity to initiate and manage change, accumulate human capital, adopt modern ways of doing things, and adapt to constant change. The plan also identified the following priority areas where capacity building was required:

- economic policy formulation and policy analysis;

- legal and judicial system reform;

- women in development;

- accounting and consulting professions;

- technical and vocational training;

- nongovernmental organizations as capacity builders; and

- encouragement of the repatriation of skilled Ugandan expatriates.

For each of these areas, the plan highlighted the key policy changes required; any changes needed in the existing institutional framework, including the creation of new institutions; and proposals for a program of action.

What are the basic precepts? First, the plan recognizes that sound economic management is an essential prerequisite for the successful development of all sectors of the economy. This means strengthening the government's capacity for policy formulation, harmonizing sectoral policies and those of line ministries with the macroeconomic policy framework, and strengthening the institutional framework for policy development and policy coordination. But there are some problems. The inadequate database undercuts the ability to make routine economic, fiscal, and monetary projections. In addition, the key agencies involved in planning and policy formulation face severe shortages of trained experts and techni- 
cians. Substantial improvements were made following the merger of the ministry of finance and the ministry of planning and economic development, but further improvements are constrained by the weak databases, skills shortage, and institutional weakness.

Second, the plan recognizes that there is a need to strengthen the capacity for policy analysis outside the government through creating a capacity for independent research in the private sector and nongovernmental organizations. As the private sector is the engine of growth in Uganda, it must be involved in the dialogue on governmental policies that affect it. To this end, the government has made significant financial contributions to enhance private sector $\mathrm{ca}$ pacity building through United States Agency for International Development grants to the Uganda Manufactures Association Consultancy and Information Services. It has also created the Economic Policy Research Center at Makerere University, but at arm's length from both the government and the university. Besides engaging in independent research, the center will have a young professionals program, in which select students from the master's program in economic policy and planning at Makerere University will train for doctoral degrees in association with universities overseas.

Third, the plan recognizes that civil service reform - creating a lean and professional civil service-is critical for capacity building. This means remunerating civil servants adequately and monetizing all noncash benefits and allowances to improve the transparency and equity of the remuneration structure. Moreover, higher civil service pay must be coupled with adequate training, retooling, provision of modern technology, and upgrading of office facilities and premises. Local experts from the nongovernmental sector should be hired on contract to bring new people into the ministries and expose civil servants to new ideas and new work ethics. And promotions should be based on performance. The hope is that improved salaries and more transparency and discipline will also reduce the temptation for civil servants to engage in corrupt practices.

Of course, civil service regulations and procedures will need to be revised to bring them in line with the new management style. This will include introducing clearer job evaluations and grading criteria; better records and personnel management systems; a focus on service delivery, with clear predetermined objectives and prespecified time frames; high standards of accounting, auditing, and financial management; and effective sanctions for nonobservance of the code of conduct for civil servants or for other misdemeanors. 
Since the publication of the capacity building plan, the government has carried out several initiatives under various donor-funded projects. These projects have assisted in the following:

- civil service reform, including reducing the number of ministries, diverting noncore functions, and decentralizating to local governments the functions specified under the 1995 constitution;

- capacity building in the legal sector and in the judiciary;

- establishment of the Institute of Certified Public Accountants of Uganda, and the training of accountants;

- strengthening the capacity for economic and financial management;

- creation of a private sector foundation as the lead interlocutor between the government and the private sector; and

- enhanced utilization of information technologies and systems.

\section{Role of Technical Assistance}

Where does technical assistance fit in? Uganda recognizes that technical assistance can play a critical role in the transfer of skills, know-how, and technology from developed countries. A particularly useful form of assistance has been donor financing of qualified expatriate Ugandans who wanted to return from exile to take up jobs in the civil service. The financing was required for transport and relocation expenses for a short period of reorientation, including settling-in allowances and modest subvention expenses, after which the returnee would settle down to normal civil service pay and conditions. In addition, considerable assistance has been provided in the form of short-term and long-term foreign expertise-as well as civil service training, either on-the-job or off-site, in the country and out of the country.

The government has insisted on managing the technical assistance itself. A government document, Uganda Policy on Technical Assistance, published in May 1993, stated that

- technical assistance must be meshed with national plans and budget priorities;

- the government would take the lead in identifying technical assistance needs; 
- technical assistance would follow a country-program approach, rather than a project approach;

- use of long-term expatriate advisers would be reduced to a minimum; and

- technical assistance would no longer focus only on the public sector but could also be extended to the private sector (including nongovernmental organizations).

\section{Good Governance}

Turning now to good governance, what exactly is it? Good governance entails publicly accountable institutions of government that are capable of making and implementing policies in an efficient, transparent, and honest manner, thereby serving the wider public interest. It also entails efficient, effective, and transparent management of public expenditure, an efficient and equitable tax regime, a fair and effective legal and regulatory framework, political accountability in free and fair elections, and the observance of fundamental freedoms and rights of human beings. Lastly, it requires a clear separation of powers of the executive, the legislature, and the judiciary, as well as a recognition of the role of an independent press and media.

Uganda has had a history of poor governance but since 1986, the government of the National Resistance Movement has been undertaking a radical restructuring of the government, aimed at improving governance, democratizing and decentralizing power, and increasing transparency and accountability. The seventh point in the National Resistance Movement's ten-point program concerns "the elimination of corruption and misuse of power."

A milestone in the restoration of good governance and the rule of law was the drafting of the new constitution. A constitutional commission was formed to canvas the views of all segments of the population, a process that took several years. It then prepared a framework for the proposed constitution that was subsequently debated in a constituent assembly elected by the people. The resultant constitution in 1995 reestablished the principle of sovereignty held by the people as the repository of political power; established democratic institutions to ensure good governance, transparency, and accountability; codified respect for human rights, civil liberties, and the rule of law; and codified the decentralization of government to 
ensure that the people had control of the decisionmaking process and the allocation of resources.

The constitution also provided for a leadership code that requires specific officers to declare their incomes, assets, and liabilities every year and to explain how these were acquired. The code prohibits conduct that is likely to compromise the honesty, impartiality, and integrity of public officers, lead to corruption in public affairs, or be detrimental to the public good or to good governance. The code stipulates the minimum standard of behavior and conduct for leaders receiving gifts and other benefits in kind. And it specifies the legal sanctions to be taken against a leader who violates the provisions of the code.

In addition, special institutions were created to deal with corruption and the abuse of power, including the Office of the Inspector General of Government, and the Auditor General-who is an independent officer of parliament reporting to the Parliamentary Accounts Committee. The various committees of parliament have also reasserted their oversight roles on the policies and expenditures of ministries and governmental departments.

This spirit of better governance is also woven into Uganda's economic reform program. The program aims at opening up and liberalizing the economy, and increasing competition, which, among other things, eliminates the opportunities for rent seeking. This is done through the dismantling of price controls, eliminating administrative allocation of foreign exchange, liberalization of all markets, and privatization of state-owned enterprises.

But liberalization is not enough, especially where there is underlying market failure. Moreover, even with liberalization there are still many areas of interface between the public and private sectors that can provide opportunities for corrupt practices. For example, in the procurement of goods and services, prices may be increased to provide for commissions to corrupt public officers. Or, in the divestiture of state-owned assets to the private sector, the assets may not go to the best bidder or even sell at the right price. In such cases, corruption needs to be minimized by increasing competition and accountability. It is also vital to increase the transparency of the interface between the public officials and the private sector, level the playing field for all private sector participants, and reduce to the barest minimum the discretion allowed to government officials in the decision-making process.

What does an effective anticorruption crusade involve? 
- There needs to be open competitive bidding for all government contracts, with clear rules of the game and full disclosure of all relevant information.

- Governmental agencies responsible for anticorruption activities must be able to effectively enforce sanctions.

- Adequate civil service salaries-which will reduce, but not entirely eliminate, the marginal value of the payoff from corruption-are necessary but not sufficient for eliminating corruption. Measures are also needed to increase the benefits of being honest, and increase the probability of a corrupt official being detected and punished.

- Auditors, police officers, investigators, prosecutors, magistrates, and judges must be honest and competent-and their agencies must enjoy independence, integrity, and adequate financial resources.

- The crusade needs to embrace a wider constituency, particularly civil society and the general public. This entails public awareness programs on how corruption leads to economic waste and poses a danger to the social fabric.

One way to do this is through national integrity workshops, which Uganda has recently held throughout the country. A national integrity survey was also undertaken to collect information on the ordinary person's experience and perceptions of corruption in the delivery of public services; provide insights into what interventions could help reduce corruption; and increase awareness among ordinary citizens of the need to tackle corruption, as well as enlist them as partners in the fight against corruption.

We intend to carry out these surveys at regular intervals and to publish the results-showing which departments and districts the citizens regard as most corrupt, and for which services the public expects to be asked to pay a bribe. This will help raise the cost of being corrupt, as the public becomes the watchdog against corruption, with the help of a vibrant and free press and media. 


\section{Comments}

\section{Kwesi Botchwey}

Uganda's overall performance has been remarkable. Indeed, it is one of the African countries that has achieved a reasonably good measure of policy soundness and has been growing quickly for a fairly extended period of time. During the period 1986-96, per capita GDP grew tremendously, by about 40 percent. From 1992 to 1997 , the growth rate of per capita GDP has been quite high, slightly over 4 percent, with inflation at a reasonably low level, about 8 percent.

Uganda's capacity building program is a comprehensive one, having the right focus and all the right objectives: economic policy analysis within the government, legal and judicial reforms, manpower planning, and retaining skilled Ugandans. As Emmanuel Tumusiime Mutebile noted in his paper, the program is informed by the policy framework that has come out of a recent initiative by the African Governors through the Executive Directors in the World Bank. This is the Partnership for Capacity Building in Africa.

In terms of design, there is really nothing on which we can fault Uganda's program. But there are some operational pitfalls, which I would like to comment on, because we tried some of these initiatives in Ghana. In fact, we pioneered some of these initiatives, such as the program to attract skilled people back to Ghana from abroad through a World Bank program. In other words, I would like to comment on the reality of implementation as opposed to mere statements of intention.

\section{It's in the Doing}

One key area of capacity building in Africa over the past decade and more has been civil service reform. There were many weaknesses in this area in the early World Bank and donor-assisted civil service reform programs. In particular, they mostly started with a 
presumptive decision to downsize to a given level, often without a real job evaluation. These were the days when downsizing was close to dogma, and it was pursued much more ardently than it is today. Rather than determining what new functions the state should perform in the context of reform, or redirecting the state in the context of liberalization, and then deciding what its size should be, the approach was just to reduce the numbers by 10 or 15 percent.

Policymakers also wanted to provide better incentives in the civil service, especially for higher management. In practice, this meant trying to stretch the ratios between the top and the bottom levels. But given budget constraints and the generally low level of incomes-which prompted unions and civil service associations to push for higher pay-there was often very little room for maneuvering. Thus, good intentions apart, these programs failed to provide any real incentives for the top levels, and very soon after, cynicism and frustration set in, with little being achieved. This was our experience, and I suspect it was Uganda's as well.

In the area of skills mobilization, Mutebile talked about retention of skilled Ugandans. We tried that in Ghana, too. After all, it makes no sense to talk about building new capacity if you cannot retain the best individuals that you have. We received donor and World Bank funds for this purpose, as did Uganda. These funds included the cost of repatriation plus a lump-sum settlement, after which the repatriated nationals began to receive normal civil service pay.

The program was very useful initially, at least in Ghana, and I suspect in Uganda, too. But the program ran into difficulties for two reasons-lack of funds to sustain the program indefinitely, and moral hazard. Those who stayed in the country often felt a little aggrieved that we were suddenly finding all this money to repatriate people who, in their view, had fled the country when times were rough, for greener pastures. Those who stayed asked why the country should spend $\$ 10,000$ to resettle each national, when they were languishing.

The program, therefore, created a lot of political and moral problems that were difficult to resolve. In the end, we decided that there were certain skills that were in such desperately short supply that we would live with this moral hazard and just bring a few people in. But operationally, the program creates problems unless it is carried out in the context of a general improvement in salary and living conditions for public servants as a whole.

Another area is decentralization. We often approach the task by decentralizing where we think the localities have the greatest stake in 
ensuring that expenditures are better used. In Ghana, the constitution actually stipulates that a given percentage of government revenues goes to the districts. But often this decentralization occurs before steps are taken to ensure that the political structures at the local level are well established so that people can express themselves and are empowered enough to take charge of what happens in their assemblies.

Policymakers must also ensure there are sound fiscal systems at the local level before decentralizing. What happened in Ghana was that we had a list of contractors who had been banned from the ministry of finance because we knew them to be rogues. A few months after decentralizing, I noticed that these individuals were not coming to the ministry of finance anymore, and I was pleased, thinking that they had finally left the system. But to my dismay, I discovered that they were doing a thriving business in the district councils - either no one was watching them, because the district assemblies were not functioning properly, or where the assemblies were functioning, they had quickly made friends with the leaders in the assemblies.

So the bottom line is to ensure that the political and fiscal systems at the local levels are strengthened, or you risk simply replicating the malfeasance that was present at the national level at the local level.

Mutebile also talks about the legal structure and the creation of a legal framework for private sector development. There have been a number of initiatives in Uganda, as elsewhere, setting up private enterprise foundations to facilitate a dialogue between the public and private sectors. This is very helpful indeed. The problem, however, is that these initiatives often concentrate only on improving the workings of two offices-the attorney general's office and the solicitor general's office-the latter often provides legal opinions for World Bank agreements. The reality is that unless the entire legal machinery is improved, contract enforcement or expedition of the legal process will not take place.

The legal reform program that Uganda has been following is strikingly similar to what other countries have undertaken. I suspect that at the operational and implementation levels, it is bound to have been bedeviled by some of the same difficulties.

\section{It's in the Design}

Why do countries run into so many problems when it comes to implementing capacity building programs? I think at the macro level, the basic problem is one of a singular lack of ownership 
of these programs. This, in turn, gives rise to a number of other problems.

First, there is undue reliance on foreign consultants-a situation that has improved only marginally in recent years. Foreigners simply do not have sufficient knowledge of what goes on in the country, nor do they have the needed commitment. And frankly, in a large number of cases, at least in my experience, they were not the most competent people.

Second, many of the programs are project driven, particularly those with the World Bank. They come as part of a project. There might be a telecommunications project, a transport project, and a project implementation unit. Suddenly you have these islands of pseudo-excellence but they are islands of people who are highly paid, implementing projects in a general environment where people are poorly paid.

Now, sometimes, this is inevitable. When you have a $\$ 300$ million project, you have an obligation to ensure that it works. But such large pay differentials between foreigners and nationals must be acknowledged as a short-term phenomenon, and steps taken to ensure that it does not continue after the project is over. Better yet, the project should be undertaken in a general framework, in which the public sector system, as a whole, is improving.

Third, the reforms tend not to reflect local realities. As a resultand I think this is the saddest commentary on capacity building in Africa-over the past 15 years or so, close to $\$ 5$ billion a year has been spent and there is very little to show for it. I am happy to note that the World Bank itself recently conducted a thorough review of its technical assistance programs, and some efforts are being made to correct the imbalances.

In contrast, I have to say that a lot of countries speak quite favorably of technical assistance programs coming through the IMF and the United Nations Development Program. Indeed, this was one of the findings of a recent external evaluation-which I participated in - of the IMF's concessional lending facility, the ESAF. ${ }^{1}$ The technical assistance programs had often been requested by the countries themselves, and the IMF and the United Nations Development Program, often acting in concert, had responded to these requests. The right people were found, they came to do given tasks, and then they

\footnotetext{
IInternational Monetary Fund, External Evaluation of the ESAF: Report by a Group of Independent Experts (Washington, 1998).
} 
left. Many countries found these programs to be much more effective than the general, project-related technical assistance programs that they find themselves saddled with.

Fourth, the long-term capacity building that the country must engage in, basically through its education system, has tended to suffer from what I consider to be a false tension between basic education and tertiary education. It is almost as if outlays for tertiary education are considered to be a waste of funds. This is very troubling indeed. The only problem with public resources for tertiary education is if they are used to provide subsidies, especially for students who can afford it. After all, tertiary education helps create the manpower to meet the country's professional needs.

Fifth, the multiple technical assistance programs coming from different donors leads to fragmentation and a lack of transparency on outlays. Very often, donors are reluctant to reveal the time spent on consultants, making it difficult to determine the efficiency of the end use of these resources.

\section{What Can be Done?}

What can be done to improve the situation? I think that, especially now that the reform effort has been going on for so long, no African country lacks a general acceptance of the need for reform or the types of reforms needed. One good thing about the reform experience, whatever else is wrong with it, is that in no time at all, if you are a government minister or a senior official in a ministry, you realize that you need to step up your capacity just to manage and monitor the implementation of these programs.

So the conviction is there, and I think we must repose some trust in the governments to be able to determine their own capacity buildings needs. The starting point must be a nationally driven, coordinated program of capacity building that acknowledges both the long- and short-term project management implications.

The role of aid must be a partnership with governments to respond to the national needs. I am pleased to report that there is some progress on this front.

- A number of people have been trained-and are still being trained-in economic management and policy analysis through the African Capacity Building Foundation, which the World Bank established a few years ago with a number of bilaterals. 
- A number of policy analysis centers have been created, which after a long trial period, have begun to undertake independent analyses. When these centers first started, many people, including myself, were highly critical. We thought that we should have started at the other end-improving the government's capacity for policy analysis-before we created independent units. But in the end, the centers were created, and they have begun to make a contribution in many countries.

- Africa's capacity for networking in economic research has improved significantly, through the auspices of the African Economic Research Consortium.

- An umbrella group for a coordinated, nationally driven capacity building effort has been launched in the form of the Partnership for African Capacity Building, as I mentioned earlier. It has done an excellent job of appraising what has gone wrong in prior initiatives, and it has proposed a new $\$ 200$ million trust fund to pilot nationally driven programs in a number of countries. The hope is that, over time, many of the donors, including the World Bank, will collapse their own capacity building initiatives into this framework. The program has run into some difficulties, however, with questions being asked about the chances of such a program succeeding and whether African countries can be trusted to use this $\$ 200$ million, when in fact $\$ 5$ billion is already being spent on capacity building. These are all very interesting questions indeed. But happily, they are being addressed, and I am confident that in the framework of this new initiative, we will begin to see a more viable effort on capacity building.

Finally, on the matter of good governance, which is why we talk about capacity building at all, Mutebile dwells on that at length. I would just like to quickly say that clearly, corruption is not a peculiarly African disease. It comes with the environment and the overall context of deterioration that often precedes these reforms-although I agree it is not a matter of pay alone. The idea is to strengthen the public institutions that are charged with seeing to the efficient and transparent use of public resources, so that these institutions can fight corruption in an ongoing way. I am happy to see that in Uganda this is being done, as indeed, it is in a number of countries.

As for the role of civil society, I think that civil society in most African countries is beginning to wake up to its responsibilities. 
There are, of course, some problems with nongovernmental organizations such as what exactly are they and to whom are they accountable? But that aside, I think there is a certain revival of interest in civil society organizations and civil society in general, and they, together with elected parliamentarians, are perfectly capable in Africa, as elsewhere, of maintaining the kind of oversight that is required to ensure that public funds are used sensibly. I do believe that this is the best approach, rather than launching witch hunts against this or that public official.

\section{John Roberts}

I would like to comment from the donor's perspective on our role in supporting capacity building in government and public administration, with the objective of integration in mind. After all, the Maastricht Treaty dedicates the European Union to the objective of working for better integration of developing countries into the world economy.

Successful integration into the world economy-through beneficial trade, investment, and an exchange of information-calls for a focused, effective, and efficient government that provides conditions of stability for the private sector, inspires the confidence of investors, and creates the conditions for human development and poverty reduction. In other words, governments must practice good governance, which in the technical sense (as opposed to the political and legal senses) means the efficient and effective fulfilment of governments' tasks and roles.

There is not much debate about the tasks of government. The core functions include: managing the macroeconomy, including the budget; delivering public services, chiefly through programs of public expenditure; and maintaining civil peace and justice, and a good environment for the private sector by regulating, arbitrating, sanctioning, and ensuring the conditions for the fair and efficient functioning of markets.

But these tasks cannot be done in a vacuum. They require knowledge and policy capability-which means understanding conditions and changing circumstances, identifying and weighing options, taking and applying decisions, publicizing decisions, and convincing skeptics.

One way to look at good governance is to see it as a hierarchy of building blocks that, in ascending order, are the following: 
- staff-their capabilities and individual competencies;

- systems - the way staff carry out the tasks of government;

- ethos-the spirit within which government functions are fulfilled, plus controls and incentives to prevent dysfunctions; and

- leadership - a sense of vision, purpose, and objectives.

Of course, capacity building problems arise at each level, so I would like to examine these levels one at a time, focusing on what roles we can expect African governments to fulfill.

\section{Bottom Rung-Staff}

Let us start with the bottom rung of this hierarchy-staff. The individual capacity of staff depends on sound recruitment, training, career planning, supportive staff management, manpower budgeting, and remuneration structures.

Where do donors fit in? They can help with training programs, training for trainers, and support for staff colleges. They can also help by introducing innovation, new curricula, and best practice in staff-training methods.

What donors should not do is to create special units of highly paid staff_-such as project implementation units, which Kwesi Botchwey just referred to-or provide salary supplements to key personnel. Doing so may have short-run attractions in terms of donor objectives, but it has negative spillover effects on institutional functioning and might even create perverse incentives. The European Commission (EC) fully supports this stance, which has also been endorsed by the World Bank's Special Program of Assistance for Africa, that groups donor organizations in a common approach in support of adjustment and reforms in low-income and indebted sub-Saharan African countries.

\section{Next Rung-Systems and Institutions}

The very effectiveness of staff on the ground, however, depends crucially on the nature and functioning of the institutional environment in which they work-that is, the systems and institutionswhich brings us to the next rung on the hierarchy.

If institutions are ineffective or dysfunctional, or if they lack clear missions and purposes - as is often the case- the design and implementation of institutional change becomes a priority task. 
The much discussed "second generation" of structural adjustment reforms on which many African countries are embarking is, in fact, an agenda of institutional change and development.

Institutional change and development are huge, multifaceted topics. We are talking about the definition of institutional purposes and structures, including those of the government and public sector as a whole. We are talking about systems of financial planning, management, control, and audit. We are talking about systems of staff recruitment, promotion, remuneration, and personnel management. We are talking about systems for diffusing information, internally and externally. We are talking about systems of institutional self-examination and self-improvement, including internal and external staff inspections, performance assessments, and audits. And we are talking about systems for ensuring policy and administrative coherence, including policy reviews and the setting and enforcing of priorities-which are vital if different parts of the government are not to be going off in their own directions.

Of course, institutional development can be a minefield for donors. They are often working with sociopolitical realities that they understand only imperfectly. Formal organigrams and reporting structures are often misleading about the way institutions actually operate and about how decisions are taken. The real systems may be based on unseen loyalties and rewards. Nepotism and sectional interests can capture institutional agendas and vitiate attempts to introduce good managerial practice.

So where do we start? Despite what has been said here today about the problems with external consultants, I believe that management consultancy is a standard way of diagnosing problems in public administration and introducing institutional change. For example, the United Kingdom has actually been through various periods in which institutional change in central and local government has been brought about through the use of outside management consultants. So I do not believe that there is anything particularly demeaning about suggesting that African governments might want to put themselves through the same hoop.

Management by objectives-setting and measuring output and performance measures, and basing rewards on their achievementis the most common technique for ensuring effectiveness at the individual and institutional levels. Preconditions for the success of management reform in government are a political commitment to the ends and means, and an acceptance of change by a broad sec- 
tion of the staff concerned, which might combine internal commitment and temporary external stimulus.

What can donors do to help? If political commitment is assured, donors can mobilize advisory resources that bring diagnostic skills and adapt international best practices to local needs and circumstances. To date, they have done this most successfully in three key ways:

- technical assistance, which primarily supports the central management and control functions of government-such as ministries of finance, tax authorities, accounts and audit departments, central banks - and is often associated with support for structural adjustment;

- financial support for retrenchment programs; and

- financial and technical support for sectorwide development programs, based on local policy ownership and an open dialogue on implementation.

This is part of a recent effort by donors to avoid some of the pitfalls that Botchwey just referred to that arise with the traditional project support. Through the sectorwide approach, donors have contributed to policy coherence and efficient resource allocation.

I think donors have made the biggest inroads in the less culturally specific aspects of systems and institutional development including: tax and tax administration reform; public expenditure planning and review; public expenditure management, control, and audit; and public sector retrenchment programs.

Success, to date, however, has been more partial in long gestation "second generation" reforms and where local political interests are more offended by reforms. These include:

- Deeper civil service reforms-many countries have not achieved the salary cost savings combined with higher administrative effectiveness that staff redeployment, salary decompression, and better personnel and career management were supposed to bring about.

- Bank restructuring and financial market supervision-financial sector liberalization and banking and supervision reforms have not always produced the sound financial institutions needed to provide the private sector with a wide range of competitively priced financial services.

- Privatization and the contracting out of public services to private operators-in fact, privatization has still only made mod- 
est headway in Africa, with a certain lack of transparency giving privatization a bad name in some spots; and governments have yet to build a substantial base for the transparent design and management of contracting out for services.

- Local government reforms-many African countries are pursuing the decentralization of administration, bringing it closer to the people, but institutional capacity and accountability problems at the local level mirror those in central government.

- Parliamentary oversight of government-this involves strengthening the capacity of public accounts committees to investigate and call ministers and officials to account for their stewardship of public resources and administrative effectiveness. In a number of African countries, the institutions of accountability to parliament exist, and efforts are underway to build the capacity of auditors and parliamentary examiners, but this vital democratic function is not always as high as it might be in parliamentary priorities.

- Strengthening law enforcement agencies and the judiciary-the rule of law, whose value is universally acknowledged, not least by the signatories of the Lomé Convention, is still only imperfectly applied for reasons of institutional capacity, resources, and corruption.

How does the EC fit in with this agenda in Africa? The EC has been putting particular emphasis on budgetary and public expenditure processes, institutional reforms in the social and public works sectors, and capacity building in local government. In the future, it will also be paying more attention to legal and regulatory aspects of government that are of greatest concern to the private sector.

The philosophy of the EC is that technical assistance should not be a long-term substitute for local institutional capacity or for requisite institutional reform. On the contrary, it should be a short-term catalyst for change, provided in cases where there is a will to pursue necessary reforms and where these reforms stand a good chance of lasting success.

A prime lesson learned from experience by the EC and other donors is that governments must be proactive, committed, and intelligent customers for technical assistance to work effectively. Capacity building among staff gives poor results if the institutional environment is not supportive. Moreover, institutional reform and 
capacity building may be subverted in the absence of an ethos of public service and a commitment to performance.

\section{One Rung Higher-Ethos}

This brings me to the next rung in the hierarchy of the characteristics of good public administration-ethos. Public service ethos covers probity, a sense of equity, respect for the rule of law and for the views and interests of civil society, and a disinterested dedication to pursue policy objectives with efficiency and effectiveness.

Ingrained habits of secretiveness, arbitrariness, nepotism, indiscipline, and corruption can quickly undermine and render ineffective the best-laid plans for institutional reform-indeed, reducing financial and personnel management procedures to a charade. Moreover, clientelism and patrimonialism - the belief by some in the power structure that the country's assets belong to them-can undercut reforms. These attitudes arise from a deep-seated sense of social obligation and from behavioral norms, but they frustrate the stated objectives of public institutions and stand in contradiction to the ethos of public service.

What can be done? These problems are essentially matters to be dealt with through local political, incentive, and disciplinary processes. And here I should highlight Uganda's efforts, as brought out by Emmanuel Tumusiime Mutebile, to introduce a favorable ethos in which public administration can function.

External partners in development actually can do little to change ethos. It is true that structural reforms may remove some opportunities for corruption that are linked to economic controls. But they also introduce more opportunities, linked to privatization and contracting for the private provision of public services. What donors can do is help with the establishment of institutional checks and balances-both within and outside public administration, for example with financial control and audit systems; public procurement procedures and practices; parliamentary oversight of government; and strengthening civil society's capacity to dialogue with the government, through support for research and policy analysis outside the government.

So the rule of law, democracy, and information-and freedom of the press-to which Lomé Convention signatories commit themselves-are necessary, but not sufficient. There must also be a political will within the government and civil society, and effective systems 
of enforcement and redress. The EC is keen to support the small but growing number of nongovernmental organizations and research organizations in Africa that observe, analyze, inform, and pressure governments to listen to civil society and live up to their commitments.

But when entrenched customs, practices, and social obligations stand in sharp contradiction with public service ethos, the routine political processes of democracy, the routine legal processes of the rule of law, and the routine administrative process of discipline may be insufficient to bring about ethical change. These circumstances call for committed leadership to instill the ethos of good governance.

\section{Top Rung-Leadership and Ownership}

This brings me to the top rung of the hierarchy-leadership and ownership. Leadership that is prepared unreservedly to take ownership of programs of institutional change and strengthening holds the key to successful development cooperation, particularly in cases where there are profound problems of capacity and ethos.

Leadership means an ability and willingness to persuade and convince relevant political constituencies of the need for particular policies. In the absence of leadership, useful reforms may be temporarily imposed by external funding agencies, but there can be no confidence in their sustainability. And unsustainable reforms are not credible to private sector players, which means they are of little help in preparing countries for globalization.

\section{Conclusion}

To conclude, a development partnership aimed at furthering good governance and the better stewardship of public resources requires both partners to take the initiative. External partners can move up the hierarchy of good governance components, starting with developing the capacities of individual staff and advancing into the wide domain of institutional reform and institutional capacity building. They have often lost their way, however, in a mist of alternative agendas, in the absence of a clear commitment to public service on the part of their host country counterparts-the question of ethos. Indeed, development cooperation has been most successful where the host country has shown a strong spirit of public service and strong leadership. 
The EC is now reflecting hard on its cooperation with the African, Caribbean, and Pacific countries after 2000, when the current Lomé Convention ends. No doubt we will see a more selective pattern of partnership emerging, with a greater concentration of effort and resources on those countries that select themselves by their commitment and their political credibility.

\section{Reinold van Til}

We are all aware of the requirements of government, including aspects of efficiency and capacity building. I have five observations.

First, on civil service reform. We know what the origin of civil service reform was, namely, the urgent need to reduce government wage bills in many African countries. In many cases wage bills were successfully lowered relative to GDP or total government expenditure, but as public employment was not reduced, pay scales were compressed and civil service wages declined in real terms. The gap between public and private sector wages has widened, which has complicated further the objective of raising productivity and efficiency in the civil service. Many would argue that the quality of civil service has deteriorated over the years.

Second, wondering why civil service reform did not succeed, one must ask the question of whether it is possible to reform the civil service from within, or is it necessary to lift certain functions outside the core civil service and to entrust them to quasi-autonomous bodies? It is noteworthy that where certain functions have been removed from the established civil service, the efficiency of government has improved-for example, in autonomous revenue authorities, privatization agencies, export promotion agencies, tourism agencies, and investment promotion centers. When these same functions have continued to be performed within the established structure of government ministries, even after reorganizations and reforms, they generally have not been executed well. This raises an important issue, namely to what extent is it desirable to have a proliferation of different remuneration and personnel management systems in government. Is this the direction civil service reform should be heading?

Third, let me say a few words about accountability and transparency. Accountability and transparency begin with good accounts and good accountants. The government's budget is the key. It is 
thus remarkable how often official budget outcomes are not reported alongside budget plans, and if they are published, the delays are often so long that these outcomes have become almost irrelevant for policy formulation and budget preparation. Although offices of auditor generals and accountant generals do not lack the manpower, there is apparently little incentive to perform these functions properly and with the necessary urgency. Should government accounts and audits be lifted out of the core ministries and put in a separate agency, with a separate remuneration structure and personnel management system?

Fourth, performance-based remuneration and promotion systems are very much in fashion these days. In the discussion, these two are often not distinguished, which is unfortunate because of their different implications for public administration. It is indeed a very good idea to have a performance-based promotion and demotion system. The administrative requirements are fairly limited; it is not too difficult to distinguish between bad and good performers. The situation, however, is quite different with performance-based remuneration systems. They require much more fine-tuning, can easily overburden the administrative capacities of ministries, and can easily lead to cronyism and favoritism, because they are less visible and transparent.

My final point is technical assistance and capacity-building. I fully agree with Kwesi Botchwey on this issue, namely that the enormous resources that have been spent on technical assistance have not produced commensurate results. Certainly, technical assistance has often produced good results in terms of the product. But why has the demand for technical assistance not diminished? Apparently, the capacity-building aspect of technical assistance has been much less successful. Technical assistance has not resulted in more do-it-yourself; instead, it has been used as a substitute for tasks that should be carried out by local officials. The responsibility for this state of affairs lies with both the providers and the receivers. We often see that technical assistance is too easily accepted as a quick solution to immediate problems, instead of contributing to lasting capacity building. In the end, technical assistance can only be meaningful and successful if it establishes the capacity for self-help, and does not displace government officials. 


\section{General Discussion}

\section{Capacity Building and Good Governance}

Godfrey Simasiku of Zambia opened the brief discussion by seconding Reinold van Til's comment that some functions of government were best reformed from without. The revenue authority in Zambia was a good example. After being separated from the government, revenue had tripled, enabling the government to finance a number of projects. A similar success story was the now independent export board, helping nontraditional exports to triple in a short period of time.

This sentiment was shared by Gray Mgonja of Tanzania, who felt it was best to reform the civil service by spinning off some of the functions, rather than the traditional approach of retrenchment. This worked because it automatically reduced the size of the government, and in the process, redefined the function of the government.

Jan Cedergren of Sweden, with a donor point of view, agreed with Kwesi Botchwey's observation that capacity building programs tended to run into trouble because of lack of ownership. Calls for a better dialogue between the private and public sectors, for more information and better transparency, and for better credibility and trust in policies were really calls for improved ownership of the economic reform program. Indeed, this was a central message of the recent external evaluation of the ESAF and the external evaluation of the World Bank's Special Program of Assistance for Africa.

Piero Ugolini, picking up on Botchwey's comment that a lot of countries speak quite favorably of IMF-UNDP technical assistance projects, suggested that a key reason why was because these projects take a global approach-modernizing the central bank in several areas at once. So far, this approach has primarily been tried in Eastern Europe, but there have been two such projects in Africa, one in Namibia, and on a larger scale, in Zambia. His one note of caution, however, was that it "takes two to tango"; the recipient country will have to be willing to move ahead on several fronts at once. 


\title{
8
}

\section{Quality and Composition of Public Spending in Africa: Suggestions for Increased Effectiveness}

\author{
Luca Barbone ${ }^{1}$
}

\begin{abstract}
A frica lags behind the rest of the world in human development. A Recent data show that the infant mortality rate is 91 per 1,000 live births. The total primary school enrollment rate is 75 percent, with the figure for females lower at 67 percent. Only about 50 percent of the population has access to safe water, and there are about 11 main telephone lines per 1,000 people.

Tremendous work thus remains for improving the quality of life in Africa and of assisting Africans to improve their own lot. Donors, business, and most governments hold the view that market development is the key to poverty reduction. Yet, there remains a substantial role for government in ensuring that rules promote competition and bring out the best of what each country has to offer, and in providing basic services when markets fail or externalities are to be found.
\end{abstract}

Alongside the poor social conditions (I say alongside because causality can go both ways) Africa suffers from a crisis of statehood-that is, a crisis of capability, as the World Bank's 1997 World Development Report points out. Public institutions are not always ef-

${ }^{1}$ The views presented here are the author's alone. Many thanks, without implication, are due to Mike Stevens and Christos Kostopoulos. 
fective, the rule of law is not always dominant, and checks and balances are at times lacking, so power can be abused. This clearly inhibits governments from delivering quality services, be they specific social services in a narrower sense, or an institutional environment conducive to economic growth and poverty reduction in a broader sense. Moreover, government behavior is responsible for, or reinforces, the crisis in statehood.

For the development community, the crisis poses a problem in strategy. Providing development projects with imported materials and management is a relatively simple task. ${ }^{2}$ But how does one assist countries to attain development objectives while at the same time abstaining from direct management control in respect of a borrower's sovereignty and in an attempt to build up the borrower's capacity to manage?

This paper will explore these questions after looking at the crisis in budget management and its roots. The proposed solutions are based on ongoing work at the World Bank to monitor the effectiveness of public expenditures, and on popular reflections on the role of institutions in shaping policies and the delivery of public services. A key recognition stemming from this work is the importance of institutions and the difficulty of reforming them-or, as is the case in many African countries today, resurrecting them after their demise.

To borrow from Douglass North, the 1993 Nobel Laureate, economic institutions consist of formal rules, informal rules, and enforcement mechanisms for those rules. In the past, we have been preoccupied with introducing formal rules, but have accomplished little-as political reality and institutions shape each other continuously, with no guarantee of a desirable outcome. In the future, we should also focus on informal rules, in part because they shape political reality, which in turn shapes government activity. Thus, the challenge for reformers throughout Africa and the donor community is to find a way to stimulate incentives so that both formal and informal rules are aligned to permit an effective use of public resources.

\footnotetext{
${ }^{2}$ In a similar fashion relating to the private sector, foreign direct investment is often successful because foreign technology and foreign management use local labor. But notice that foreign investors have control, and they are not interested in cultivating domestic managers until the operation is already running smoothly. By contrast, development assistance tries to provide project and management training concurrently, while respecting the sovereignty of the borrower.
} 


\section{Crisis in Budget Management}

Just how poorly are budgets managed in Africa? A World Bank study of public expenditures and budgetary practices and outcomes in 22 African countries ${ }^{3}$ reveals some interesting, albeit probably not surprising, facts:

- Budgets generally remain only an approximate guide to the actual allocation of resources, despite several years of technical assistance and budgetary reforms that were driven by Policy Framework Papers. ${ }^{4}$ As Figure 1 (top panel) shows, over onethird of the countries had a discrepancy greater than 30 percent between the allocation of resources decided at the time of budget formulation and the outcomes. Less than one-half registered what could be considered a moderate deviation of 10 percent or less. These figures should give us pause, as they imply that for a large majority of African countries, budgets are a figment of the imagination.

- What is even worse is that the resulting unpredictability of resources results in wide variations-even within sectors-in the allocation of funding. Figure 1 (bottom panel) shows that in a large number of countries, the sectoral destination of resources within priority sectors has not been respected. Funds for schoolbooks go for ministerial limousines. Allocations for rural health centers get diverted to white-elephant heart centers.

- All this happens because accountability, as evidenced by expost controls, remains low. Indeed, Figure 2 shows that only one in seven countries manage to produce audits of public expenditures within a year of completion of the fiscal year. By then, it is old news and the political debate is already centered on next year's priorities. Thus, ministers do not really have to account for their actions-or inactions.

Certainly, these are bleak pieces of evidence-all the more distressing because most of the countries surveyed have benefited from considerable assistance from the World Bank, the IMF, and a

\footnotetext{
${ }^{3}$ See Christos Kostopoulos, Progress in Public Expenditure Management in Africa: Evidence from World Bank Surveys, Africa Region Working Paper Series, No. 1 (Washington: World Bank, 1999).

${ }^{4}$ Policy Framework Papers are forward-looking documents drafted by the national authorities in collaboration with the staffs of the World Bank and the IMF.
} 


\section{Figure 1}

Budgets Do Not Tell the Story ...

Discrepancies in Budgets vs. Outcomes

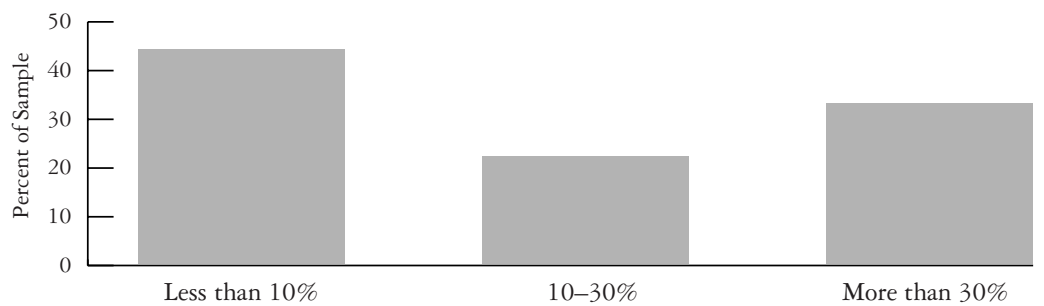

... Even for Sectoral Allocations

Share of Countries with More Than 30\% Discrepancies in Budgets vs.

Outcomes

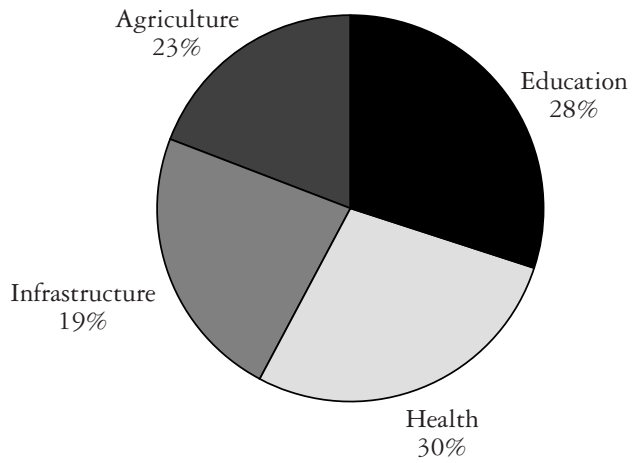

Source: Christos Kostopoulos, Progress in Public Expenditure Management in Africa-Evidence from World Bank Surveys, Africa Region Working Paper Series, No. 1, (Washington: World Bank, 1999).

score of foreign donors. It should be emphasized, however, that the aggregate picture masks a lot of variation, and there are a number of encouraging examples, such as Botswana and Uganda. Nevertheless, it is not an exaggeration to argue that the failure of the state institutions is a major determinant of the limited progress in the improvement of human development indicators.

\section{Roots of the Problem}

To better understand the reasons for the crisis of the state in Africaand the role of the donor community in this crisis-it is useful to bor- 


\section{Figure 2}

How Timely Are Audits?

Timeliness of Line Agency Audits After the Fiscal Year

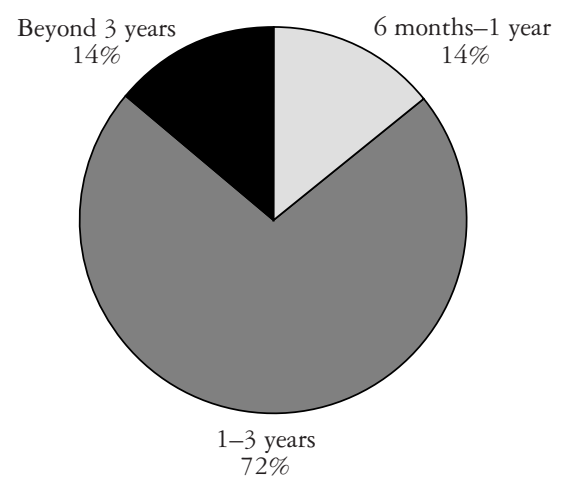

Source: Christos Kostopoulos, Progress in Public Expenditure Management in Africa-Evidence from World Bank Surveys, Africa Region Working Paper Series, No. 1, (Washington: World Bank, 1999).

row from a World Bank study coordinated by Malcolm Holmes ${ }^{5}$ that classifies official budget systems as operating at three levels.

- Level 1 is the capacity of the budget to achieve the government's fiscal objectives-the level with which the IMF is concerned (budgetary discipline).

- Level 2 is the capacity to allocate resources according to the government's strategic objectives (political choice), essentially a political process, but one disciplined by cost.

- Level 3 is the capacity to deliver services efficiently and effectively.

All the levels are linked. For instance, effectiveness (level 3) is certainly influenced by political and program choice tradeoffs (level 2), along with budgetary limits and intersectoral discipline (level 1).

To characterize in a schematic way the sequence lived by many African countries over the last two decades, one would say that the initial mandate given to the state in defining its level 2 priorities was very ample. This reflected the ideologies of the time, which emphasized the direct intervention of the state not only in the provision of

\footnotetext{
5World Bank, Public Expenditure Management Handbook, Poverty Reduction and Economic Management Network (Washington, 1998).
} 
public goods and services but also in the setting of development priorities in the productive sectors. Institutions were created to fulfill these mandates, but over time a breakdown of fiscal discipline emerged (destruction of level 1) - the result of external shocks and low growth caused by the excessive mandate of the state-leading to unsustainable macroeconomic outcomes that required correction. These corrections, however, were carried out in an environment of both increasing resource constraints and shifting, but as yet not well redefined, paradigms. As a consequence, across-the-board cuts, rather than a refocusing of mission, were the rule. It is no wonder that under these circumstances, institutions crumbled and the ability of the state to deliver basic services was reduced (level 3), accompanied by rising corruption and a lack of accountability.

So how does the donor community fit in? It is not too much of an exaggeration to argue that donors, despite the large amounts of resources deployed, have often taken a narrow view of assistance to Africa. They have been guided by the principle of project implementation, measuring success by the degree to which implementation-and only later development-objectives have been met.

In doing so, the donor community has often failed to recognize that foreign aid plays into the three levels at which budgets operate and profoundly affects the system of incentives faced by policymakers and bureaucrats. The availability of foreign financing for projects-nominally determined jointly with governments, but in reality driven by donor considerations and affinities-becomes a substitute for an effective reform of level 2. In conjunction with the requirements of level 1, donor assistance can become a vehicle for undermining institutions and the effectiveness of the state (level 3) as resources are directed toward areas that receive funding to the detriment of a coherent institutional strengthening strategy. And although some rudimentary services may be delivered because of donor financing, the notion of statehood is undercut, as service delivery is not based on self-reliance and confidence building, but on handouts.

In short, capacity is not being built from the ground up; rather, already low capacity is just being supplemented with technical assistance. Foreign assistance becomes part of the political tradeoffs in an arena of institutions that are often new to the region. Democracy is one such institution; statehood is another. Public administrations in one sense are political outcomes. And national budgets, to which we attach so much importance, are part of that outcome. 


\section{A Strategy for Reform}

With this in mind, what is the appropriate strategy for reform and ultimately for increased effectiveness of public expenditures? The key is institution rebuilding.

First, assuming that the task of overall budget stabilization is accomplished, concentrate on fixing level 2. A sharp refocusing of the state's priorities is badly needed. Depending on the nature of the markets, measures should be taken to increase contestability (through proper regulation or market-making measures); divest the state (in its broader sense) from activities that do not form part of its mandate; and use alternative delivery mechanisms (witness the role of the private sector and the civil society in the Democratic Republic of the Congo) where it can be presumed that these will work better.

This has begun to occur in a number of cases, but much too often the reality is that the state's capacity has withered away under the pressure of bringing budgets under control to meet fiscal objectives. An emphasis on retrenchment, necessary as it may be, often results in a wholesale demoralization of the civil service and increased incentives for corruption, as the choice between integrity and starvation is an easy one. Rather than reducing state involvement and concentrating on core capacities-while increasing the role of the private sector and civil society in providing public goods and services-the initial strategy (or lack thereof) results in an overall deterioration of capacity.

Unfortunately, implementing a strategy for reform is proving to be a challenge, even in countries that recognize the scope of the challenge. The problem is that everything depends on everything else, and adopting the right sequence of reforms is a tricky endeavor indeed. Technical solutions will not work by themselves. The decomposition of institutions is such that the introduction of, say, a new budgeting system or computerized large taxpayer units is likely to be rejected by the system, rather than contribute to its reform. Similarly, technical assistance aimed at civil service reform is a glaring example that generally meets with negative results.

So what can be done? We increasingly realize that ingredients for success must include:

- top-level support and determination;

- a buying-in of existing personnel; and 
- work on simultaneous fronts-redefining the mission of the state, revamping revenue capacity, reforming the civil service, allowing civil society and private sector participation, and modifying the systems and incentives at the institutional level.

Above all, it should be clear that reform of the state takes time to be effective. The practice of using adjustment lending or the formulation of Policy Framework Papers as the occasion to "negotiate" imaginary civil service reform timetables, for instance, is one of the elements that may lead to a formalistic buy-in of reform, and ultimately to its chances of success.

\section{Role of the Donor Community}

While the responsibility for successful institution rebuilding must rest primarily with the African leadership, the substantial amounts of resources still accruing to them imply that the donor community can also have a great impact. In particular, the project enclave mentality that underlies much donor assistance must be replaced by an approach that emphasizes institution building, resource predictability, and accountability of public officials — or the odds will be stacked against reform.

How can this be done? First, by gradually switching the emphasis from individual projects to medium-term expenditure frameworks. Second, by focusing on institution building-recognizing that institutions are inputs as well as outcomes-rather than simply capacity building. And third, by introducing transparency, accountability, focus, and vision, and designing projects so that their performance is monitorable.

\section{Role of Medium-Term Expenditure Frameworks}

An MTEF is aimed at moving toward an integrated program approach with "internal consistency" between political and development objectives, domestic and foreign aid resources, and management capacity. Most importantly, once the MTEF has been agreed upon by government, donors, and stakeholders, it should provide a stable basis for decision making in the management of expenditures. The World Bank and other donors have three roles to play: serving as honest brokers between political players to maintain the MTEF agreement; assuring program financing with bud- 
getary aid, all the time staying flexible; and maintaining traditional project lending as part of an MTEF. Ideally, if there were complete agreement on an MTEF, covering the entirety of the budget, donor assistance would not need to remain project specific-support to the budget would be all that is needed. Toward this end, the World Bank is now working on a new class of lending instruments.

But how can we arrive at a budgetary process that incorporates MTEFs as integral parts of its architecture? Clearly, what is required is a quantum leap away from the old practice of compiling public investment plans. A workable MTEF needs to assess country needs in the short and medium term, take stock of current and projected financial and management resources, and adjust activities to achieve high priority outcomes given finite resources.

The government's commitment, therefore, is essential for the MTEF approach to succeed. Resource availability must be assessed in a realistic way, so that the government's own commitments under the MTEF can be fulfilled (sometimes this may involve simply maintaining teachers' salaries). In addition, an assessment of the scope of the state's mandate and managerial capacity should lead to partnerships with the private sector and nongovernmental organizations for services they are best suited to provide. Indeed, partnerships with the private sector are now commonplace in the transportation and telecommunications sectors, and have also gained prominence in the education sector-in some countries with the assistance of nongovernmental organizations.

\section{Role of Monitoring}

A crucial element of keeping a medium-term project on track is monitoring - in essence, the buzzword for obtaining management information. ${ }^{6}$ Of course, monitoring requires financial resources, and these need to be programmed up front as part of overall project costs. So which indicators should be monitored? I would like to suggest three steps.

The first step is to establish desired project outcomes-an approach that differs markedly from the past focus on implementation rather than development objectives. Examples of outcome indica-

\footnotetext{
${ }^{6}$ Roberto Mosse and Leigh Ellen Sontheimer, Performance Monitoring Indicators Handbook, World Bank Technical Paper No. 334 (Washington: World Bank, 1996).
} 
tors would include employment (and salaries) of graduates for a technical school project, and earnings of farmers based on shifts to new crops in an agricultural extension project. These indicators are difficult to obtain and sometimes materialize only after the project's completion. Nevertheless, it is vital to establish them at the project design phase, and to seek out those indicators that allow for early tracking of project performance. As outcomes make several assumptions about factors unrelated to the project that still affect project performance (be it climate or GDP growth), it is important to single these out and identify potential risk factors.

The second step is to establish project or program outputs. These are tangible goods and services-deliverables-for which the project is responsible. They might refer to the number of graduates from a technical school, or the number of methods learned by new farmers. Monitoring outputs is a more doable task, and such indicators are often compiled by project managers, implementing agencies, or auditors. Similar to outcome indicators, output indicators require assumptions that need to be articulated. For instance, many projects rely on partner contributions (be they national or district governments, nongovernmental organizations, or other donors), and associated risks need to be spelled out.

The final step is to devise indicators for monitoring the progress in implementation of the project. These are the input indicators. They measure the various processing stages of project implementation and are among the easiest to gather. In the technical school example, inputs would be classrooms built and teachers trained; in the agricultural example, they would include the number of seeds delivered.

\section{Conclusion}

In summing up, Africa's low level of human development is a consequence of the political and economic institutions that influence the provision of social services. So far, project assistance from donors has proven simply to be a Band-Aid approach-and one where the patient is constantly changing positions, so the Band-Aid eventually comes off. For there to be a consistent delivery of services, there needs to be both a stable flow of resources and sound management.

How can a stable flow of resources be assured? This will require a commitment on the part of the government. As budgetary alloca- 
tions are often the result of political decisions, "de-politicizing" of the allocation process will help. Introducing donors as "budgetary partners" with clear developmental objectives and financing may also go a long way.

How can sound management be assured? For this, policymakers and donors need to think in terms of desired outcomes over the medium and longer term, breaking objectives into modules, and monitoring performance. Such an approach will improve the quality of public spending and contribute to the much needed capacity building in Africa. 


\section{Comments}

\section{Gray Mgonja}

There are two underlying issues raised in Luca Barbone's paper. The first is that given resource constraints, governments have to prioritize public expenditures. The second is that there has to be a framework that ensures that resources indeed are made available to the priority areas in the most efficient manner and that the intended impact can actually be assessed.

We start with the premise that the resource envelope available to governments is small. Yet governments of sub-Saharan Africa have a daunting role to play to improve the quality of life of their people-in other words, to reduce poverty. Because public resources are limited, Barbone says rightly that donors, business, and most governments hold the view that market development is the key to poverty reduction. But conditions for market development in Africa are not fully in place, and thus governments have to provide resources to create the enabling conditions, which include infrastructure in the form of transportation systems, communication, energy, regulation, and human resources. Moreover, in the short run, market development is not expected to deliver the basic social services. And even if it could, social service delivery alone may not be sufficient to create the conditions for economic growth.

There is a consensus that economic growth and stability are critical for poverty eradication-indeed, they are perhaps the most important prerequisite for development. We know that without growth, the government's capacity to spend cannot increase. Yet to achieve growth, there needs to be long-run investment in both economic and social infrastructure. Thus, the question is how to mobilize resources and deploy them in the most effective manner to produce the desired results.

One important way is to establish and maintain macroeconomic stability. In Africa, this means fiscal discipline, which means auster- 
ity, which means cutting expenditures, which in turn means less expenditure to the very sectors that require government financing. The debt burden also takes away a sizable amount of government resources, dampening the government's capacity to create the environment for growth.

In Tanzania, for instance, on a per capita basis, the government is spending nine times as much on debt service as on basic health, and four times as much on debt service as on primary education. ${ }^{1}$ What is the overall trend on social service outlays? If you compare the 1990s and the early 1980s, expenditure on social services has declined. But if you look at the period 1994-98, outlays on social services have increased. In fact, expenditure on health has risen substantially. Even so, it is not enough. The share of expenditure going to social services is still low compared with the share going to other sectors.

So we have a vicious cycle here. But, of course, life must go on in the manner proposed in Luca Barbone's paper, which is the adoption of a medium-term expenditure framework. This will enable governments to identify and articulate priorities for public expenditure, within the constraints of resource availability. And on this point, I would like to make a comment on Barbone's introductory remarks where he said that budgets do not really mean much because they are not related to what actually happens in terms of allocation. I think one point that must be borne in mind is that budgets will be disrupted if there is a shortfall in projected resources, as budgets are made on the basis of projected resources. So whenever resources-both domestic revenue as well as donor or loan disbursements-fall short of target, the budget is disrupted, meaning that expenditure plans are disrupted.

Another important way to mobilize resources and ensure they are used effectively is, as Barbone points out, to move to the program approach as opposed to the project approach. Here, donors are agreeing to adjust their interventions toward a more coordinated approach than has been the case. We also need greater ownership by the recipient governments-of course, with proper

\footnotetext{
${ }^{1}$ These figures include domestic debt service and scheduled external debt service; if the figures were adjusted to include only domestic debt service and external debt service actually paid (i.e., after debt relief), the ratios would be cut by about half.
} 
accountability. This means that the formulation and articulation of priorities in the context of a medium-term expenditure framework has to be the responsibility of African governments. This will be a departure from the past, where public expenditure reviews were influenced by the wishes of external parties whose terms of reference were prepared in Washington. Missions were undertaken, and volumes of reports were written, only to find their way to shelves as the host governments did not have the incentive to care about the contents and their usefulness.

In Tanzania, until recently, many senior government officials were not truly aware of what public expenditure reviews meant. They considered them to be the property of the World Bank. This phenomenon has changed, however, with the preparation of the current medium-term expenditure framework. The request for such a framework originated with the government. It asked the World Bank to assist in developing a budget guidelines paper, focusing on the priority sectors that the government had already designated-education, health, roads, water, and energy.

Two drafts have been produced, and donors have been asked to provide comments, including information on donor resource flows, both in the recent past and commitments for the next three years. This is rather interesting because we do not even have complete information on bilateral donor flows into Tanzania, including technical assistance. Why? Because of the problem of the project approach. The project approach is such that certain resources are disbursed, but information is not provided to the government.

A promising step is that discussion of the framework will be organized soon with all the stakeholders-including donors. We hope this goes a long way toward addressing public expenditure issues and, of course, takes on board the proposals contained in Barbone's paper.

\section{Emmanuel Tumusiime Mutebile}

Luca Barbone's paper raises a number of pertinent issues. I would like to comment on two of these in particular: the role of donors in enhancing sustainability in public service provision and capacity building in the public services, and how to improve the planning and monitoring of public service provision. 


\section{A Role for Government}

Barbone begins by reiterating the need for a substantial role for government in providing basic services. I would add that because levels of basic service provision are so low in much of Africa, the potential returns to public expenditures should be very high, provided that these expenditures are well targeted and efficiently implemented. Moreover, as Barbone notes, Africa suffers from a crisis of state capabilities. The human consequences of allowing the state to deteriorate to the point of collapse-when even basic security for people and property can no longer be ensured-are catastrophic, as has been seen in several countries on the continent including Uganda over the 1971-86 period. Preventing this collapse should be a priority.

The collapse of the state of Uganda led to an economic collapse that shifted the composition of economic activities, as measured by changes in the structure of GDP. ${ }^{2}$ There was a shift away from activities that were vulnerable to war, such as manufacturing, to activities that were less vulnerable, such as nonmonetary agriculture. This happened because a breakdown of the state leads to insecurity, which changes the economic relationships within the private sector. This happens in three ways.

Enhanced incentives for opportunism. Insecurity makes more visible any mobile assets that are more likely to be stolen or expropriated. Insecurity also affects the incentives faced by individuals in their personal conduct. It does this by drastically shortening people's time horizons, which has a direct impact on the incentives for honest - as opposed to dishonest or opportunistic - behavior. When people are expected to behave in an honest fashion, then it usually pays to conform since dishonest behavior is obvious to the rest of society and is straightforward to sanction.

Breakdown of social capital. The shortening of time horizons also affects those institutions that can be thought of as mechanisms for guaranteeing long-term commitments. Insecurity affects the incentives faced by individuals who constitute or operate institutions such as the legal system or the accounting profession. A perceived shrinking of prospects of promotion or the chances of continued job security leads to increased rent-seeking behavior and erodes the reputation of the

${ }^{2}$ Emmanuel Tumusiime Mutebile and N.M. Henstridge, "Africa, Markets, and Underdevelopment," paper presented at Queen Elizabeth House, University of Oxford, July 6, 1995. 
institutions where they work. Specific individual past behavior is inferred from what is normal in society. The elimination of the presumption of trust (which is a collective public good) and other publicly provided mechanisms that initiate against dishonest behavior-such as the legal system, prompt enforcement of contracts, credible audit, and standardized weights and measures-make the detection and sanction of dishonest behavior harder. It then becomes easier to survive by being dishonest because honesty does not pay.

Increased transaction costs. This happens because transactions between individuals can no longer rely on any presumption of trust, and because the institutions for contract enforcement have broken down. The increase in transactions costs leads to a sharp decline in the transaction demand for money and a demonetization of the economy.

\section{Capacity Building and Institutional Development}

So where do donors fit in? Barbone bluntly admits that foreign aid has done little to build sustainable capacity to deliver public services in the recipient countries, but he does not answer the question of why this is so. One reason is that much of the technical assistance provided by donors is focused on individuals, or on individual projects, and not on building public institutions. For example, a large amount of donor resources are spent on providing academic and vocational courses, workshops, and the like for public servants, often abroad. But in many cases, the content of this training has only a tenuous connection to the actual duties of the public servants, and when it is relevant, its value to the public service is often lost when the individual leaves public service in search of better remuneration elsewhere.

Paradoxically, the brightest and best-trained public servants, who will have gained the most from donor-funded capacity building exercises, are among those most likely to leave public service. Their skills are highly marketable and sought after-not least by donors, international organizations, and nongovernmental organizations, who pay salaries that the public service cannot compete with. The resultant brain drain is a major impediment to enhancing efficiency in public institutions, and will be halted only by improving the salary structure and providing better career prospects.

Barbone recognizes that capacity building requires institution building. In this context, I would like to note one point of particular relevance to the World Bank. The type of detailed conditionality 
for structural adjustment loans increasingly imposed by the World Bank and the IMF can be counterproductive to long-term institution building. A key aspect of institution building is creating institutions that can take and implement public policy decisions serving the wider public interest-despite the opposition of vested interests, especially those with strong political influence. This is not just a question of the technical capacity of these institutions but of their relationship with the political process and the wider society. Forcing the authorities to take politically difficult decisions through conditionalities may have short-term economic benefits. But because it removes the responsibility for taking these decisions, it may impede long-term institutional development.

A key aspect of institution building relates to personnel policies and management. The weaknesses in these areas are another reason why the resources devoted to capacity building have had limited benefits. Better management training and systems of personnel management-along with greater attention to evaluating candidates' personal management skills-are needed if the public service is to be made more efficient.

Efficiency can also be enhanced by introducing private-sector types of incentives and management strategies - for example by creating autonomous agencies to deliver services with performancebased pay for their staff, or by contracting services out to the private sector. This will help promote an essential change in the management culture of the public service, which needs to put greater emphasis on performance and efficiency, rather than on maintaining existing programs and their associated budgetary allocations.

\section{Planning, Monitoring, and Accountability}

Barbone offers two solutions to the problem of developing efficient and effective public services: the medium-term expenditure framework and monitoring.

\section{Medium-Term Expenditure Framework}

The introduction of MTEFs in a number of countries-including Uganda-supported by the World Bank and donors, has been motivated by the desire to improve long-term expenditure planning, consistent with available resources, developmental and political objectives, and management capacities. The MTEF 
sets out the budget strategy and strategic choices, and prioritizes expenditures across all sectors, within a resource envelope determined by the macroeconomic framework. The MTEF process enables line ministries to participate more actively in budgetary planning and, given the hard budget constraint, forces them to focus more clearly on key goals and priorities and thus, vital expenditure allocations within their own particular sectors.

The shortcoming of MTEFs in many countries is that they include only recurrent and domestically funded capital expenditures-excluding donor-funded projects, which in most African countries comprise the largest share of the development budget. As a result, the development budget is often a collection of individual projects, which do not necessarily form a coherent investment program or reflect the overall sectoral priorities of the government. Sectoral investment plans have gone some way in addressing this problem, at least with regard to intrasectoral investment allocations. But the optimal solution would be to integrate all development projects into the MTEF, with donors financing a share of the overall development budget rather than individual projects.

The efficacy of the MTEF to deliver improved expenditure quality depends on the medium-term stability of the macroeconomic environment and available resources. Shortfalls in revenue that force unanticipated cutbacks in budgetary allocations can severely reduce efficiency in service provision, as cutbacks are often concentrated on the procurement of goods-meaning that public servants have insufficient materials with which to do their work. This underscores the need either to reduce the economy's vulnerability to exogenous shocks by diversifying sources of government revenue, or to impose fiscal adjustment to get a better balance between revenues and expenditures.

Ever since Uganda started on economic reforms back in 1987, the government has recognized that budget discipline is a nonnegotiable issue. In a country like Uganda, where the monetary sector is shallow and instruments of monetary policy are lacking, aggregate fiscal policy is the key instrument for delivering macroeconomic stability. Much of Uganda's success with pursuing a wide-ranging and ambitious reform program can be attributed to its commitment and success in maintaining overall macroeconomic stability since $1992 / 93$. For the last five years, the average annual rate of inflation has been in single digits, compared with triple digits before the reform program began. 
While overall fiscal control may be the necessary starting point, the composition and quality of expenditures are also critical if the budget is to succeed in delivering necessary services in a cost-effective way. In a country such as Uganda, with low tax revenues as a proportion of GDP, achieving the most appropriate composition and the best quality of what expenditures can be afforded is vital. When money is short, achieving allocative and technical efficiencies are all the more important. In this connection, in recent years Uganda has focused on two areas:

- creating an enabling environment to facilitate the needed increases in private investment for sustainable broad-based growth-including macroeconomic stability, reductions in the cost of doing business in the private sector, and complementing markets rather than displacing them; and

- focusing budget resources on areas critical for poverty reduction - such as primary education, primary health care, and infrastructure-where market failures impede the optimal participation of the private sector and where equity considerations apply.

One indicator of the evolution in expenditure policies is Uganda's Public Investment Plan for capital expenditures. Over a four-year period, from $1995 / 96$ to $1998 / 99$, it shows the government withdrawing from areas well suited to the private sector-with budgetary allocations to agriculture dropping from 12 percent to 5 percent-and an elimination of all budgetary allocations to manufacturing. Over the same four-year period, the Public Investment Plan shows government commitments to investments in transportation and communications rising to 42 percent from 17 percent of total public expenditure.

\section{Monitoring}

There is undoubtedly a need to put more emphasis on targeting the performance of public services rather than simply controlling inputs. But Barbone's proposals for monitoring performance may not be feasible as many governments lack the capacity to make detailed assessments of the effectiveness of expenditures. The manpower resources needed for this type of monitoring are considerable. The problem is compounded by poor data. Indeed, the data needed to evaluate project or pro- 
gram outcomes - for example farmers' earnings in an agricultural extension project-will not be available in many cases.

Certainly, greater accountability would help improve performance. This can be done by making the public expenditure process more transparent, thereby involving the public as a complement to the government's own monitoring efforts. In Uganda, there have been sharp increases in budget allocations channeled through districts-for sectors such as primary education, primary health, and feeder roads - as part of a decentralization process. Budget transfers to each district are announced by advertisements in the press, while the districts are required to publicly display the amounts received and transferred to individual schools, and the schools are also required to display the amounts received. As a result, all stakeholders, from members of parliament to parents, know what transfers are taking place and, therefore, can demand accountability.

\section{Sectoral Composition of Public Spending}

Another issue that is central to the quality and composition of public spending is what happens at the sectoral level. It is now widely accepted that the composition of public expenditures has a major impact on both the efficiency of public expenditures, in terms of social rates of return, and on their distributional effects.

Thus, there are two basic rules that should govern expenditure choices:

- Public expenditures should be focused on supplying goods and services that, because of market failures, the private sector will not supply in an optimal manner, such as pure public goods or goods subject to positive externalities. This mainly involves inter-sectoral choices.

- Within this category of goods, the government should focus expenditures on items that are most cost-effective. Often this involves intrasectoral allocations, such as between primary and curative health care. But even within the same sector, different types of interventions can vary widely in terms of cost-effectiveness. This means that estimating the cost-effectiveness of different interventions - even if these are of necessity only tentative estimates-and using these estimates to guide intrasectoral allocations, could have a large impact on the cost-effectiveness of overall sectoral spending programs. 
Recent budgetary reforms in Uganda have focused on reallocating expenditures to raise social rates of return and reduce poverty. Uganda accords a high priority to providing universal primary education, with overall expenditures (both capital and recurrent) having doubled in real terms in the last three years. Primary education expenditures have high social rates of return and a strong, positive, long-term impact on equity and poverty alleviation. The Organization for Economic Cooperation and Development estimates that the social rates of return to primary education in Africa is 24 percent. Primary health care, such as mass immunization programs, has similar benefits.

Although there is a strong consensus that primary education and health care should be a priority in budgetary allocations, there are other areas where choices are less clear-cut, such as infrastructural provision and support for agriculture. More work is needed to determine which expenditures within these sectors are most cost-effective, and where the private sector should be encouraged to play a greater role.

Governments also need to be aware of the potential tradeoff between rates of return to spending and the impact on poverty. The incidence of poverty tends to be highest in the rural areas where farmland is marginal, hence agricultural productivity is very low and production is vulnerable to drought. But because farmland is marginal and population densities probably lower than elsewhere, rates of return to spending in these areas may not be as high as areas with greater agricultural potential. Nevertheless, expenditures in marginal areas may be justified because the impact on poverty reduction-especially the reduction of acute poverty-may be strongest in these areas.

\section{Takuma Hatano}

I would like to make some comments on the role of the government in the building up of infrastructure.

In 1997, the Export-Import Bank of Japan conducted a survey, in close collaboration with the World Bank, on private infrastructure investment. We found that the overall investment in developing countries for infrastructure buildup was around $\$ 250$ billion, with private investors accounting for about $10-15$ percent of the investment. We also know that the share of the private sector is increas- 
ing. And for countries like Chile, Pakistan, or the Philippines-and in Africa, for Côte d'Ivoire-private infrastructure investment is emerging as a growing area for project financing.

Let me take the case of Pakistan as an example. Pakistan embarked on its first independent power project roughly eight years ago, with the World Bank and Japan's Export-Import Bank providing a partial political risk guarantee. Eight years ago, the maximum term of a commercial loan to Pakistan was five years; in other words, long-term commercial financing was not available. But under this scheme, commercial loans with a maturity of 15 years were syndicated, and the bids were actually oversubscribed.

The point here is that investing in infrastructure is basically attractive to private investors, provided that economies are stable and regulatory frameworks are reliable. So how can governments help attract private investment? I would like to explore three ways.

First, in the developing world, 80 percent of investment still rests in the hands of the government or public sector. This means that the efficiency of those investments is vital-in particular, the government's subsidy must be minimized or streamlined as an initial step. According to the World Bank, actual subsidies in this area are sufficient to finance all the necessary amount of new investment without any additional government borrowing. Also vital is the optimal combination of private investment and public investment. Take Indonesia, for example. We are now working on a big independent power project there-Paiton II, a coal-fired power generation project-which will be completed in 1999. But the construction of a transmission line, which the government is handling, has been delayed. Of course, this may reduce the rate of return for investors in the power project.

Second, the role of government is fundamental when it comes to planning capacity and a reliable regulatory framework. To facilitate private investment in infrastructure, we have found that the role of the government should be to change from project owner or manager to project planner and regulator. But planning capacity is very scarce, not only for developing countries but also for some industrialized countries. In Japan, for example, because of the lack of planning capacity, the private sector's share of infrastructure investment is still very low, even less than that of Côte d'Ivoire and France. By contrast, in Indonesia, the planned capacity of independent power projects now well exceeds future demands for power.

The pricing policy is also vital. In India, the authority to issue power licenses rests in the hands of the local government, and the 
local government heavily subsidizes the tariff to the farmers. With many local governments running a deficit, however, investors consider this situation unsustainable. Of course, India is such a big country that there is much private investment in the manufacturing sector, but it is striking that there has been no sizeable private investment in infrastructure. In other words, private sector investment in infrastructure is a different story.

The third area is the importance of macroeconomic stability-a lesson from the recent Asian financial crisis. To begin with, a country needs foreign exchange stability. The way independent power projects are set up, the entire foreign exchange cost is passed through to the wholesale price, which the national power company must pay investors and lenders. Thus, if a currency is devalued, the gap between the wholesale price and retail price, which is the basis of revenue for the national power company, becomes negative or enlarged.

Let us look at what happened in Indonesia in 1998. At an exchange rate of 6,000 rupiahs per dollar, the wholesale price of power under an independent power project was around five to eight cents per kilowatt. But the post-devaluation retail price, in dollar terms, was only two cents per kilowatt. The solution for this negative price gap would have been to raise the retail price, but this was politically impossible to do as a quick adjustment. As a result, the national power company, Perusahaan Listrik Negara, fell into serious financial difficulties. In fact, after the company's president told parliament that it was nearly insolvent, one of the European banks announced that Perusahaan Listrik Negara was in default. This is the kind of lesson we should learn from the Asian crisis.

Fiscal soundness, of course, is also important. Under the independent power project arrangement, the government generally undertakes or is expected to undertake responsibility for the obligations of the national power companies. But this is an off-budget obligation, a contingency liability for the government. Let me give two examples.

In the Philippines, the foreign debt of the National Power Corporation amounts to about $\$ 5$ billion, which constitutes 20-25 percent of the nation's total foreign debt. Because most of the National Power Corporation's debt is, in fact, guaranteed by the government, and the utility strictly produces a local product-that is, no exports-if the currency is devalued, the utility's financial burden suddenly increases.

In Indonesia- unlike in the Philippines - the government does not provide a legal guarantee, but it does undertake to provide support 
for the national power company. We lenders call it the comfort letter for the obligation of the power company. But if several large independent power projetcs are completed in the near future, it is quite likely to be difficult for the national power company to honor paying the wholesale tariff to investors. If this happens, the magnitude of this public debt would be far from negligible, as these obligations constitute almost 10 percent of the government's annual budget.

In conclusion, the answer to the question I raised at the beginning of how governments can help attract private investment-is in three ways. They can do this by ensuring that public investment is efficient, providing a sound regulatory framework, and pursuing sound macroeconomic policies. In other words, governments stand to play a decisive role in private infrastructure investment.

\section{Jan Willem Gunning}

It is a pleasure to comment on Luca Barbone's excellent paper. It is a thoughtful contribution on a very important topic and I very much agree with most of his points. In this comment, I would like to focus on three issues: the effectiveness of donor monitoring of public expenditures; the reasons for poor provision of public services; and the issue of ownership.

\section{Donor Monitoring of Public Expenditures}

That donors are concerned about the level and the composition of public expenditures is unsurprising. What is surprising is that in Africa this legitimate concern has led to attempts by donors to monitor public expenditure in minute detail. Even in countries where government policies enjoy broad donor support, donors seem obsessed with the details of government spending. The representative of a major donor in Uganda once remarked to me that it would have been highly desirable to place a "spy" in the ministry of finance; this would enable the donor to get more detailed information on public expenditure.

I have three objections to this donor obsession with fiscal monitoring.

- Monitoring is, of course, intrusive and the use of spying terminology is very revealing. Detailed monitoring unnecessarity adds to the strain of the relationship between donors and governments. 
- It may well be misguided. The donor may be deluding himself when he thinks that the expenditure accounts measure what they purport to measure. A recent World Bank study that tracked public expenditure in Uganda found that less than 40 percent of nonsalary education expenditures actually reached the schools. ${ }^{3}$ Hence a study of the data in the ministry of finance in Kampala would give a very misleading impression of public expenditure on schooling.

- As Barbone rightly stresses, the focus on measuring the costs of inputs is misplaced. The current system of monitoring, at best, establishes how much is spent on schools, not what is achieved with that money. Current monitoring is heavily biased in favor of measuring project implementation rather than project results. The preoccupation with inputs rather than outputs reflects a worrying disregard for efficiency. The 20/20 Initiative of the Copenhagen Summit is a good example where the emphasis is not on results but on ensuring that recipient governments devote at least 20 percent of their expenditure to health, education, and other social sectors.

Barbone departs from this method. He advocates the monitoring of outputs rather than the inputs of a project. This is a welcome step towards performance-based lending. ${ }^{4}$ What I am somewhat skeptical about is when he seems to suggest that measuring outputs is not only necessary but also sufficient, so that public service provision will be satisfactory provided that outputs are monitored. This is like saying a patient's fever would go away if only his temperature were taken often enough.

\section{Public Service Provision}

There is now substantial literature on public service provision in Africa. ${ }^{5}$ A key lesson from this literature is that while public service provision is extremely poor by almost any indicator, this cannot be

\footnotetext{
${ }^{3}$ Emmanuel Ablo and Ritva Reinikka, "Do Budgets Really Matter? Evidence from Public Spending on Education and Health in Uganda," Policy Research Working Paper No. 1926 (Washington: World Bank, 1998).

${ }^{4}$ Paul Collier and others, "Redesigning Conditionality," World Development, Vol. 25 (September 1997), pp. 1399-1407.

5 Paul Collier and Jan Willem Gunning, "Explaining African Economic Performance," Journal of Economic Literature, Vol. 37 (March 1999), pp. 64-111.
} 
attributed to insufficient spending. Potentially productive government expenditure (excluding defense spending and interest payments) is actually higher in Africa (as a share of GDP) than elsewhere. ${ }^{6}$

The literature suggests a number of reasons for poor public service provision. One is that in many African countries the state was captured by narrowly based, urban elites who used the public sector to create jobs for the rapidly growing group of urban, educated workers. With the objective of job creation paramount, wage levels were reduced and nonwage expenditure was squeezed-resulting in low productivity levels. In addition, public service delivery became heavily biased in favor of the urban elites. For example, while outside of Africa the amount spent per university student is 3 to 14 times as high as the amount spent on a primary school pupil, in Africa the ratio is $44 .^{7}$

Another reason for poor public services is that where civil liberties were constrained, the power of popular protest was undermined, and thus low returns on public projects went unchallenged. ${ }^{8}$ If such explanations are right, the monitoring that Barbone advocates will find the symptoms of the disease but it will not address the fundamental problem.

\section{Ownership and an Appropriate Role for Donors}

Lack of ownership has become a very serious issue in Africa. This was a major theme in our external evaluation of the IMF's concessional loan facility, the ESAF, 9 and is also stressed in Barbone's paper. He usefully distinguishes three levels of government activity. For the second level, that of political choices, he says that donors should be "honest brokers between political players to maintain the MTEF agreement." Here I strongly disagree. However well intentioned donors may be, I cannot see how they can play a role as brokers between political players without fundamentally undermining ownership. It is not right for donors to enter the political discussion on a medium-term expenditure framework.

\footnotetext{
"Sanjay Pradhan, "Evaluating Public Spending: A Framework for Public Expenditure Reviews," World Bank Discussion Paper 323 (Washington: World Bank, 1996).

${ }^{7}$ See Pradhan (1996).

8Jonathan Isham, Daniel Kaufmann, and Lant H. Pritchett, "Governance and the Returns to Investment: An Empirical Investigation," Policy Research Working Paper 1550 (Washington: World Bank, 1995).

International Monetary Fund, External Evaluation of the ESAF: Report by a Group of Independent Experts (Washington, 1998).
} 
At a more technical level, I welcome the switch from evaluating projects to a broad assessment of the government's fiscal stance. But here, in my view, Barbone does not go far enough. His broad assessment still involves quite detailed monitoring of "the number of graduates from a technical school" or "the number of methods learned by farmers." This would still leave thousands of indicators to be monitored by donors-which seems difficult to reconcile with ownership. The sort of performance-based lending that I and others have advocated would limit the donor's assessment to a few key variables (e.g., aggregate growth and investment, poverty, and literacy). Donors would stand ready to offer advice, but they would let governments decide how to achieve such broad targets.

\section{Sanjeev Gupta ${ }^{10}$}

This session raises a number of important questions about how the government can strengthen its role in improving the formation of human capital and physical infrastructure; how to strengthen the links between government spending and the delivery of public services, especially to target groups; and how to measure progress in this area.

While Luca Barbone's paper stresses the links between government spending and the delivery of services, and the importance of monitoring project implementation, it only briefly notes the need to improve public expenditure composition in African countries. I will, therefore, dwell on this issue in some detail, complementing Barbone's presentation on the microeconomic aspects of project implementation, management, and monitoring. The reason for this focus is that IMF-supported adjustment programs are not only concerned with the level of government spending, but also the quality and composition of this expenditure. ${ }^{11}$

In terms of the budgetary framework laid out in Barbone's paper, the IMF is thus concerned not only with budgetary discipline (level 1) but also the effectiveness of expenditure (level 3 ).

\footnotetext{
${ }^{10}$ The author wishes to thank Ke-Young Chu, Christian Schiller, Benedict Clements, Calvin McDonald, Edgardo Ruggiero, and Rosa Alonso for advice and assistance in preparing this comment. Erwin Tiongson provided computational help.

${ }^{11}$ George T. Abed and others, Fiscal Reforms in Low-Income Countries: Experience Under IMF-Supported Programs, IMF Occasional Paper No. 160 (Washington: International Monetary Fund, 1998).
} 
While the IMF respects member governments' political choices concerning the allocation of budgetary resources (level 2), we also recognize that how these resources are allocated has many vital economic implications for external adjustment and growth-areas in which we collaborate closely with member governments.

\section{Formation of Human and Physical Capital}

In Africa, as Barbone notes, human development and the formation of human capital is still lagging behind other regions of the world, and there is a continuing need for governments to finance social services. One way that African governments could further accelerate the formation of human and physical capital is through allocating a higher share of budgetary resources for education, health, and capital formation. The question is whether such a change in the composition of expenditures is taking place in Africa.

A review of spending patterns for 22 African countries supported by the IMF's concessional ESAF during 1985-95 shows that these countries have made distinct progress in improving the composition of spending, although by somewhat less than inititally envisaged (see Table 1). These countries were able to boost capital spending as a share of GDP, in part reflecting better project implementation capacity. ${ }^{12}$ But current spending declined as a share of GDP, in part due to lower spending on wages, salaries, subsidies and transfers. Does this shift from current to capital outlays bode well for Africa's long-term growth potential? That is difficult to determine, as information on the quality of this additional public investment is not readily available.

Moreover, progress was uneven across regions. In the CFA franc zone, for example, subsidies and transfers increased, on average, while capital spending and net lending declined as a share of GDP, owing in part to sharp declines in these outlays in a few selected countries. ${ }^{13}$

For Africa as a whole, we also see improvements in the functional distribution of spending (see Table 2). Outlays for military spend-

\footnotetext{
${ }^{12}$ This does not necessarily imply there was an increase in infrastructure spending, as these outlays include capital spending in education and health. The issue of whether infrastructure spending rose is addressed in the context of the discussion on changes in the functional distribution of spending.

${ }^{13}$ In Togo, for example, capital expenditure and net lending fell by 7.4 percentage points of GDP, and by 5.3 percentage points in Niger.
} 


\title{
What Happened to Expenditure Allocations? An Overall Shift from Current to Capital Outlays
}

\author{
Table 1. Performance in Sub-Saharan African Countries \\ Supported by ESAF Program
}

(Averages of countries in sample, in percent of GDP; data for CFA franc zone countries given in parentheses)

\begin{tabular}{|c|c|c|c|c|c|}
\hline & $\begin{array}{c}\text { Preprogram } \\
\text { Year }\end{array}$ & $\begin{array}{l}\text { Latest } \\
\text { Year }\end{array}$ & $\begin{array}{c}\text { Latest Year } \\
\text { Minus } \\
\text { Preprogram } \\
\text { Year } \\
\end{array}$ & $\begin{array}{l}\text { Actual } \\
\text { Result } \\
\text { Minus } \\
\text { Target }\end{array}$ & $\begin{array}{c}\text { Number } \\
\text { of } \\
\text { Countries } 1\end{array}$ \\
\hline \multicolumn{6}{|l|}{$\begin{array}{l}\text { Total expenditure and } \\
\text { net lending }\end{array}$} \\
\hline Current expenditure & $18.5(17.7)$ & $17.3(15.3)$ & $-1.2(-2.5)$ & $0.5(0.1)$ & $22(8)$ \\
\hline Wages and salaries & $6.8 \quad(7.8)$ & $6.1 \quad(5.9)$ & $-0.6(-1.8)$ & $0.2(0.1)$ & $22(8)$ \\
\hline $\begin{array}{c}\text { transfers } \\
\text { Capital expenditure }\end{array}$ & $2.5 \quad(1.5)$ & $2.2(1.7)$ & $-0.3 \quad(0.3)$ & $0.2(0.2)$ & $17(7)$ \\
\hline and net lending & $7.1 \quad(6.4)$ & $7.5 \quad(6.0)$ & $0.4(-0.4)$ & $-0.8(-1.1)$ & $22(8)$ \\
\hline
\end{tabular}

Source: Abed and others (1998).

${ }^{1}$ Number of countries for which data are available for a given expenditure category. If the sample size varies for different columns, the maximum figure is given.

ing, on average, were reduced as a share of GDP, as well as those for general public services (such as planning and printing), which may have reflected declining administrative costs. Encouragingly, infrastructure spending - as proxied by economic services, and transportation and communication outlays-has risen since the preprogram year, especially in CFA franc zone countries. ${ }^{14}$

How about health and education? On average, African countries were able to increase health spending as a share of GDP and to maintain spending on education. Both education and health spending rose in relation to total government outlays, suggesting that social spending became a higher priority. There were some differences in spending outlays across regions, however, as CFA franc zone countries, on average, reduced education spending as a share of GDP. A more mixed picture also emerges for increases in real spending per capita, with real health spending rising sharply for African countries as a whole and education spending falling. But the decline in education

\footnotetext{
${ }^{14}$ These data on expenditure by function should be interpreted with caution, given the small sample size.
} 
spending should be interpreted cautiously, as it reflected a decline in teacher salaries after the CFA franc devaluation, and thus does not necessarily imply fewer educational services. For a more accurate analysis of changes in the volume of social services, we would need separate deflators for both wage and nonwage costs. But such data, which would need to be consistent with the aggregate spending figures, are typically not available over program periods.

How about social indicators? Africa's increase in education and health spending has, on average, gone hand-in-hand with better social indicators, such as the illiteracy rate, gross enrollment rates, and infant mortality rates. ${ }^{15}$ Nevertheless, it is clear that achieving substantially more rapid progress on these fronts, as noted by Barbone, will require more than simply increasing aggregate social spending. Greater attention also needs to be paid to the efficiency and composition of such expenditure.

\section{Stronger Links Between Spending and Target Groups}

Next, we need to assess how well the government's outlays translate into better services, especially for targeted groups. Barbone's paper focuses on the institutional and political processes that determine how social spending is allocated. It is also useful, however, to consider how these outlays benefit different target groups, so that we can improve the composition of this spending.

Indeed, the degree to which the poor have access to education and health services is an important aspect of the link between spending and the delivery of public services. In this context, a worrisome feature of social spending in Africa is the way it has been allocated among different sectors. A large portion of social sector spending is still allocated to higher education and curative health care, which has a less favorable impact on human development and social indicators

\footnotetext{
${ }^{15}$ Since the preprogram year, illiteracy rates fell by an average of 2.2 percent a year, while gross primary enrollment rates rose by 1.0 percent. Stronger progress was made by African countries at the secondary level, with gross enrollment rates increasing by 1.5 percent a year. The repeater rate-a proxy for quality of education-improved at both the primary and secondary level, with especially sharp increases at the secondary level. Similarly, a number of health indicators improved, as life expectancy increased by 0.1 percent a year and infant mortality rates fell by 1.2 percent a year. There were sharp increases in access to health care, safe water, and sanitation, and equally rapid increases in immunization rates.
} 


\section{Education and Health Spending Becomes a Higher Priority}

\section{Table 2. Expenditure by Function in Sub-Saharan African Countries Supported by ESAF}

(Averages of countries in sample, in percent of GDP; data for CFA franc zone countries given in parentheses)

\begin{tabular}{|c|c|c|c|c|}
\hline & $\begin{array}{c}\text { Preprogram } \\
\text { Year }\end{array}$ & $\begin{array}{l}\text { Latest } \\
\text { Year }\end{array}$ & $\begin{array}{c}\text { Latest Year } \\
\text { Minus } \\
\text { Preprogram } \\
\text { Year }\end{array}$ & $\begin{array}{c}\text { Number } \\
\text { of } \\
\text { Countries }\end{array}$ \\
\hline Total expenditure and net lending & $25.9(24.8)$ & $25.1(21.6)$ & $-0.8(-3.2)$ & $22(8)$ \\
\hline General public services & $4.2(3.5)$ & $3.7(2.8)$ & $-0.3(-0.7)$ & $13(5)$ \\
\hline Military spending & $3.2(2.4)$ & $2.2(2.1)$ & $-1.0(-0.3)$ & $17(5)$ \\
\hline Education $^{2}$ & $4.0(4.1)$ & $4.0(3.7)$ & $0.0(-0.4)$ & $20(6)$ \\
\hline Health $^{2}$ & $1.5(1.2)$ & $2.1(1.4)$ & $0.6(0.2)$ & $19(5)$ \\
\hline Economic services & $5.0(3.4)$ & $5.3(4.0)$ & $1.0(0.6)$ & $13(5)$ \\
\hline Transportation and communication & n $0.8(0.6)$ & $1.1(1.6)$ & $0.4(1.1)$ & $9(3)$ \\
\hline \multicolumn{5}{|l|}{ Memorandum items: } \\
\hline $\begin{array}{l}\text { Education (percent of total } \\
\text { spending) }\end{array}$ & $13.5(15.5)$ & $14.6(16.7)$ & $1.1 \quad(1.2)$ & $20(6)$ \\
\hline spending) $)^{2}$ & $4.8 \quad(5.0)$ & $6.8(7.0)$ & $2.0 \quad(2.3)$ & $19(5)$ \\
\hline $\begin{array}{l}\text { Real education spending per } \\
\text { capita } 2,3^{2}\end{array}$ & & & $-0.7(-2.9)$ & $20(6)$ \\
\hline Real health spending per capita ${ }^{2,3}$ & & & $2.5 \quad(4.0)$ & $19(5)$ \\
\hline
\end{tabular}

Source: Abed and others (1998) for all data except education and health; Gupta, Clements, and Tiongson (1998), country authorities, and IMF staff estimates for education and health data.

${ }^{1}$ Number of countries for which data are available for a given expenditure category. If the sample size varies for different columns, the maximum number is given.

${ }^{2}$ Data on education and health are drawn from a more recent sample of 20 countries with ESAF programs, and hence are not comparable to figures on total expenditure and net lending.

${ }^{3}$ The numbers refer to average annual rates of change between the preprogram year and the latest year for which data are available.

than other forms of social spending, such as primary education and preventive health care. Let me cite a few examples.

- In education, the most recent data available for a sample of 9 African countries show that 24.3 percent of outlays were absorbed at the tertiary level, compared with 13.7 percent in 9 Asian countries and 20.4 percent for a sample of 37 developing and transition countries outside of Africa. ${ }^{16}$

\footnotetext{
${ }^{16}$ Sanjeev Gupta, Benedict Clements, and Erwin Tiongson, "Public Spending on Human Development," Finance and Development, Vol. 35, No. 3 (September 1998), pp.10-13.
} 
- In health care, outlays on curative care absorbed the lion's share of the health budget, accounting for about 65 percent of spending in a sample of 7 African countries, compared with 64 percent in 5 Asian countries and 59 percent for a sample of 26 developing and transition countries outside of Africa. ${ }^{17}$

These results largely confirm the findings of an earlier study, ${ }^{18}$ which showed that social expenditures in sub-Saharan Africa were biased against primary education and primary health care over the 1980s, with no evidence of restructuring of priorities in social spending during the decade.

So what can be done? First, a better intrasectoral allocation would increase the share of the benefits of public spending captured by the poor, as a large amount of social spending in Africa appears to be benefiting middle- and higher-income groups. A sample of nine African countries reveals that the percentage of benefits of education expenditure accruing to the poorest quintile of the population averaged 11.8 percent, compared with 32.3 percent for the richest quintile. ${ }^{19}$ And while countries like Ghana and Kenya have made some progress in improving the benefit incidence of social spending, health spending in countries like Togo remains concentrated in higher-income regions. Thus, a reallocation of spending to primary education and preventive health could improve the efficiency and equity of social spending in a number of countries.

Second, shifts in the geographical targeting of social spending would also improve its distributive incidence. For example, a reallocation of spending away from higher income urban areas to rural regions-where most of the poor reside-would in many cases en-

${ }^{17}$ These figures on curative spending should be interpreted with caution, as they are based on proxies for curative outlays as a share of total health spending. The data are drawn primarily from the IMF's Government Finance Statistics database, with spending on hospitals and medical equipment as the proxy for curative expenditure.

${ }^{18}$ David E. Sahn and René Bernier, "Evidence form Africa on the Intrasectoral Allocation of Social Sector Expenditures," Working Paper No. 45, Cornell University Food and Nutrition Policy Program (Ithaca, NY: Cornell University, 1993).

${ }^{19}$ Florencia Castro-Leal and others, "Public Social Spending in Africa: Do the Poor Benefit?," World Bank Research Observer, Vol. 14 (February 1999), pp. 49-72. For a more recent view that confirms the notion that upper-income groups disproportionately capture the benefits of education and health spending, and also assesses the incidence of social expenditure in seven African countries, see David E. Sahn and Stephen D. Younger, "Poverty and Fiscal Policy: Microeconomic Evidence" (unpublished; International Monetary Fund, April 1998). 
hance their access to public services and thereby result in a larger share of the benefits accruing to them.

Third, the mere provision of additional social services by the government is not sufficient. The quality of services has a considerable impact on social outcomes as well. Thus, there is scope for improving the efficiency of social spending by rationalization of the input mix. In many cases there are severe imbalances between wage and nonwage inputs, with a high wage bill crowding out spending on more productive inputs, such as medicine and teaching materials. Only limited progress, however, has been made on civil service reform in Africa. ${ }^{20}$ While spending on wages and salaries has been reduced in many countries, often this has been realized through decreased real wages, rather than the envisaged reductions in employment. A few examples follow:

- In Zimbabwe, all targets for reducing the size of the civil service were missed under the ESAF program, although most expenditure targets for the wage bill were met.

- In Ghana and Kenya, initial reductions in government employment were offset by new hires.

- In some countries, including Ghana and Togo, wages have absorbed an extraordinary share of current education spending, leaving little for teaching materials and maintenance spending. ${ }^{21}$ A recent study suggests that African countries are less efficient in the provision of health and education services than countries in Asia and the Western Hemisphere, possibly reflecting both the impact of relatively high government wages in the education sector and the intrasectoral allocation of government resources. ${ }^{22}$

Fourth, there is clearly a need to strengthen civil service reform, with a view to reducing low-productivity employment and releas-

${ }^{20}$ Ian Lienert and Jitendra Modi, "A Decade of Civil Service Reform in SubSaharan Africa," IMF Working Paper 97/179 (Washington: International Monetary Fund, 1997).

${ }^{21}$ In the period between the first and second ESAF programs, education spending in Ghana increased sharply, but with wages and salaries accounting for about 95 percent of current spending. In Togo, between 1990 and 1996, wages accounted for two-thirds of total education outlays, with investment spending accounting for only 5 percent.

${ }^{22}$ Sanjeev Gupta, Keiko Honjo and Marijn Verhoeven, "The Efficiency of Government Expenditure: Experiences from Africa," IMF Working Paper 97/153 (Washington: International Monetary Fund, 1997). 
ing resources for selected nonwage inputs with high productivity. Civil service reform should be seen as an essential component of the strengthening of public sector institutions that Barbone indicates is central to the World Bank's approach for improving the delivery of public services. A major shortcoming of civil service reform efforts has been an excessive focus on securing short-term budgetary savings, rather than building up the necessary civil service institutions needed for a more efficient provision of public services. ${ }^{23}$

Fifth, increasingly, countries in Africa (e.g., Benin, Ethiopia, and Uganda) are devolving spending to the lower levels of government, often aimed at aligning local preferences with public spending on critical social services. In the short run, however, this may not necessarily improve service delivery, due to weak administrative capacity at the local level. ${ }^{24}$ In Ethiopia, for example, where local governments account for over 70 percent of total spending on education and health, the efficient devolution of expenditure has been hampered by the lack of basic infrastructure and communications equipment at the local level, with some local governments even lacking telephones and electricity. ${ }^{25}$

Decentralization can also lead to lower social expenditures if local officials chose to allocate central government block grants-that are given specifically for these purposes-for other purposes. In Uganda, for example, preliminary evidence indicates that decentralization has been associated with a decrease in the share of education expenditure reaching the school level. ${ }^{26}$ Equally important is whether the resources are distributed to local governments in an efficient and equitable manner, given that the bulk of the revenue is mobilized by the central government.

\footnotetext{
${ }^{23}$ See Abed and others (1998).

${ }^{24}$ Vito Tanzi, "Fiscal Federalism and Decentralization: A Review of Some Efficiency and Macroeconomic Aspects," paper presented at the World Bank's "Annual Conference on Development Economics," Washington, May 1-2, 1995.

${ }^{25}$ For an examination of fiscal federalism issues in Ethiopia, Nigeria, and a number of other countries, see Teresa Ter-Minassian, ed., Fiscal Federalism in Theory and Practice (Washington: International Monetary Fund, 1997).

${ }^{26}$ This evidence should be interpreted with caution, as the decline in the share of resources for schools could reflect short-term transition problems in moving to a more decentralized system. See Emmanuel Ablo and Ritva Reinikka, "Do Budgets Really Matter? Evidence from Public Spending on Education and Health in Uganda," Policy Research Paper No. 1926 (Washington, World Bank, 1998.
} 
Sixth, as noted by Barbone, the role of the private sector should not be overlooked when assessing options for improving living conditions for the poor. Government actions should seek to encourage and complement private sector provision of health and education services, which is substantial in many African countries.

Finally, it is also necessary to press ahead with the "second generation reforms" that are incorporated into many IMF-supported adjustment programs. These reforms include a strengthening of the judicial system, improved transparency in public sector operations, improved expenditure management, and improved tax administration. Some of these reforms can contribute to more equitable and efficient expenditure policies. For this reason, the IMF will continue to support these institutional reforms with its technical assistance in the areas where it has expertise.

\section{Measuring Progress}

The final question is how do we measure progress in this area, and how do we move forward? We need to improve our database on social expenditures. In many African countries, there are no comprehensive data on education and health expenditure that capture fully all current and capital expenditures (including those financed by donors). We also need to collect data on the intrasectoral composition of spending that is consistent with the aggregate data. And we need to make greater use of social indicators to gauge development progress.

With this in mind, the Organization for Economic Cooperation and Development, United Nations, and World Bank have identified a working set of indicators in different areas, including education and health. Their use in assessing progress would help in understanding whether public spending is indeed having a perceptible impact on the delivery of social services. This approach would complement the indicators-based monitoring of projects that Barbone advocates to improve the efficiency of project spending in Africa. But a better database on indicators - at both the project and more aggregate level-may require that the countries themselves increase the amount of financial and human resources committed to their generation. 


\section{General Discussion}

\section{Quality and Composition of Government Spending}

Moses Asaga began the discussion by detailing Ghana's efforts to reform the budgetary system. The budget process is no longer a wish list of projects by ministries; projects must be justified and then prioritized—with the highest priority going to education, health, and infrastructure. Moreover, with a multiparty democracy, the entire process, from provisional estimates through the appropriation bill, is closely scrutinized.

Ibrabima Makanguilé of Mali suggested that Luca Barbone had left out one key factor behind the large discrepancies between budgetary outcomes and what was budgeted: as African countries became more democratic, social pressures also rose. With the education budget, for example, policymakers needed to make adjustments practically every month to respond to student demands. The education budget as a whole was huge, but if 30-40 percent was allocated to scholarships, then there was a problem.

Peter Freeman of the U.K. Department of International Development pointed to a promising development: aid was changing from a separate series of project inputs to a program of financial support directly related to the budget and sectoral priorities. This would, in turn, require changes in the way the IMF operated-some of which were suggested by the external ESAF evaluation. Freeman also noted that the budget issues that Sanjeev Gupta of the IMF had raised in his comments on Barbone's presentation had traditionally been the responsibility of the World Bank. Now the Bank and the IMF would have to carve out anew how the development agenda should be shared, as the IMF's role shifted to focus more on poverty reduction.

John Roberts of the European Commission noted that donors were now more willing to think of assistance in the form of general budget support rather than project support. They were unsure, however, what criteria should be applied, especially toward judging 
intrasectoral efficiency. Development indicators were one possibility, but broad indicators - such as those in health - might reflect a whole range of factors not controlled by the health sector budget. The answer might lie in recipient countries specifying narrow process improvements and objectives over a short time period.

Jan Willem Gunning of the University of Oxford, in response to Hirohisa Kohama's question on what form of aid would help promote ownership — a key goal of Japan's overseas development assistance-expressed skepticism that aid could be used as a carrot to alter policies. But that did not mean that donors should just sit back. The answer was to be selective. If a particular African government satisfied the criteria that Japan thought were important, then it should finance those governments. But it should do so on the basis of a broad assessment, not detailed micromanagement, and do it over the long term, not three-month monitoring. Did that mean donors should just ignore the plight of the poor living in a country that happened to be ruled by a bad government? No, there was still a case for aid, but not government-to-government aid.

Turning to Yukio Yoshimura's question as to what donors could do to improve political processes in Africa, Gunning said he was afraid that very little could be done. Yes, there were some counterexamples where donors had become angry enough to effect change. It was only temporary, however, and could not be sustained. In the end, it was not the donors' role. Perhaps an unhelpful message, he said, but an implication of ownership, nonetheless. "You cannot change political processes in sovereign countries, and trying to do so creates a mess."

In response to another question by Kohama on what was the optimal mix of private and public sources for infrastructure investment, Takuma Hatano of the Export-Import Bank of Japan drew on his experience in Asia. In the case of the power sector, typically transmission lines were financed by official overseas development assistance, and the power generation projects by the private sector. This made sense because the Asian private infrastructure projects tended to be part of an effort to privatize the sector as a whole. In the end, the national grid would be owned by the public sector (or managed by a public institution) and power generation and distribution would be in the hands of private investors.

Luca Barbone of the World Bank ended the discussion by noting that the movement away from project finance toward budgetary finance was promising, but it would necessitate a change in the culture of donors, as well as the World Bank. 
This page intentionally left blank

CInternational Monetary Fund. Not for Redistribution 


\section{9}

\section{Panel Discussion}

\section{Tomáz Salomão}

In the past, for most of the countries in Africa, globalization was something we read about, not something that we participated in. Historically, the integration of firms into interdependent manufacturing processes, the ever-extending reach of world financial markets, and the near-instantaneous flow of information around the globe has passed Africa by, and for good reasons. Much of our industry was rudimentary, many of our financial markets were closed and insular, and our communications systems functioned poorly.

Moreover, the macroeconomic environment in many countries, Mozambique included, was so poor that it made little sense for local entrepreneurs to try to participate in global commerce, except as sellers of raw materials or as purchasers of consumer goods. Worse yet, the macroeconomic environment made many investments by foreigners too risky to seriously contemplate.

Today this is changing. Countries throughout Africa are successfully adopting policies that are more business-friendly and that help to promote macroeconomic stability. Mozambique is a good example of this. Until recently, vast expanses of the economy were controlled by state-owned enterprises. But through a massive privatization effort that will be completed soon, we have sharply reduced the role of the state in the economy. In addition, we have begun to adopt a more outward orientation in our policies. Tariffs have been lowered and laws have been passed that ensure that export-oriented investment projects can obtain all of their inputs at world prices. As a result, we are beginning to see increased interest by investors in Mozambique. For instance, work has just begun on a $\$ 1.3$ 
billion aluminum smelter to be built near Maputo. Other large investments are in various states of preparation.

At the same time, we have taken significant steps to promote macroeconomic stability, by among other actions, tightening monetary policy. This was possible owing to the privatization of the state banks, which slowed leakages into the economy. In addition, fiscal policy has been tightened to ensure that the government is not a source of macroeconomic instability.

These policy changes were painful, but they have been successful. Only three years ago, inflation was averaging over 50 percent a year. While growth had begun, it was only because our economy had been driven so far down by war and drought that when peace and the rains came there had to be an expansion. But today inflation is in the low single digits, real growth of GDP is consistently in the range of 7-8 percent. Our exchange rate has stabilized, having been little changed against the dollar for the past few years and having appreciated against the rand. This has given our entrepreneurs a solid base that will allow them to participate in global commerce and made Mozambique a more favorable location for foreign investment.

It would be easy to say that the focus of Mozambique's reform should be to liberalize the economy while adopting an outwardlooking policy orientation. But these steps are not enough. I would like to focus on three additional areas that are often overlooked.

First, while we all understand the importance of allowing markets to function and of minimizing the government's interference in most areas, it is often the case that more liberal policies in one area increase the importance of a strong policy response elsewhere. The trick in government is to know when liberalization requires new and different regulation. This is well illustrated in the banking sector. In Mozambique, we have taken steps to open up the banking sector to greater competition and to allow banks greater freedom of operation. One important lesson of the recent Asian experience has been that strong banking and financial market supervision is crucial to the long-term health of the economy. We are working to develop our capacity in bank supervision and maintain this as a priority in terms of applying scarce resources within the central bank.

The Asian crisis has also shown us that the developed countries must take greater responsibility for managing their lenders. Financial flows among the developed countries have become so large that even small diversions of those funds to individual developing country markets can create severe macroeconomic consequences 
and create inappropriate incentives for companies. The efforts by the G-7 and other countries to find ways to better manage such flows will be crucial to the long-term stability of financial systems around the world.

The second issue that I would like to highlight is the need to undertake institutional reform. The importance of this issue became painfully apparent to me when I read the 1998 African Competitiveness Report of the World Economic Forum. This report ranks countries according to their performance on a number of indicators that have been correlated with increased growth in the past.

This report was a bit of a wake-up call for Mozambique. We have been quite proud of our reform efforts so far, believing that these would be enough to enable us to compete on a regional and world basis. And indeed, the World Economic Forum judged us as one of the most improved countries in Africa-a country in which the business community was the most optimistic. But also we were in the lower quarter of the African countries scored in terms of current competitiveness. This was a bit of a shock. We knew that, given the history of war and poverty in our country, we would not be on the top of the rankings but we did not expect to be ranked as poorly as we were.

Why did we do so poorly? It was not because of the normal objective measures. Our tariff rates are reasonably low, our tax rates are normal to low for the region, and our exchange rate policy is viewed favorably. Where we continuously got in trouble was in terms of policy implementation and public administration. Time and again, when businessmen were asked about the economy, they would indicate that regulations were poorly drafted, public administration was poor, and unwritten barriers to business activity were a significant burden.

This is an area of reform that needs serious work in Mozambique-and I expect many other countries in Africa and beyond. Moreover, this is an area that cannot be fixed by ministerial decrees or new laws. Instead, it will take a concerted effort over a period of years to improve the operation of the public service and to mold the laws and regulations into shapes that can be implemented with our own public service.

The third issue that we face is how to ensure that the benefits of globalization are broadly shared. While financial globalization creates work for bankers and other skilled workers, we must not lose sight of the need to create jobs for the large number of low-skilled workers in many African countries. This means adopting labor laws 
and standards that protect workers while encouraging greater employment. Moreover, particularly in a country like Mozambique, it is necessary to encourage geographical diversity of development and our regulations should take this into account.

Ladies and gentlemen, it is clear now that the effects of globalization are beginning to sweep through Africa. It is up to our governments to decide how we will respond. The reforms that have been implemented in many African countries over the past decades have positioned us to take advantage of change in world trade and finance.

But clearly more must be done. As I have noted, liberalization does not mean libertarianism. We must learn to identify those areas where it is vital for the government to play a role and then play that role well. We must also redouble our efforts at institutional reform. Unfortunately, gains in this area are likely to be slow. It is easy to change the law. It is hard to change someone's habits and way of doing business, but it can be done. And to the country that does it the best will go the rewards. This should be sufficient incentive for all of us.

\section{Koichi Hamada}

I am pleased to be here at this seminar on Africa. For many years I have been teaching about East Asian economies at a university in the United States, with my attention focused on the industrialized world. This is evidenced by my having been to Paris at least seven times, but until 1997 I had never been to Africa. My trip to Africa was as an evaluator of the IMF's concessional ESAF program, and as it turned out, it was a trip that changed my whole perspective. Instead of only looking across the Pacific from the United States to East Asia, I learned about the perspective from the other end of the world, indeed from the birthplace of the human race.

I-usually, an ivory tower economist-have long recognized the limitations of economics. Over time, I have become skeptical of the ability of economics to solve real-world problems, because economics is such a technical and abstract science. I thought the trip to Africa would make me even more skeptical about the relevance of economics. Instead, my confidence in economics was restored somewhat, as I came across many questions that could be studied, if not completely solved, by applying current economic theory. 
I would like to share with you now a few impressions from my ESAF trip, keeping in mind that African economies should be understood in and of themselves and, at the same time, in contrast to Asian economies-Motomichi Ikawa stated this clearly in his opening remarks. But also keep in mind that African economies are affected by policy decisions in other regions as well. For example, as Kwesi Botchwey mentioned, CFA franc countries must soon decide whether they should fix their currencies to the euro, making them a satellite of the new European Community instead of France. Today, I would like to focus on three problems: the problem of intertemporal choice, the problem of intermediation, and the problem of political economy.

\section{Problem of Intertemporal Choice}

Let us start with the elementary macroeconomic identity that exports (X) minus imports (M) essentially equals savings (S) minus investment (I). In other words, the current account of the balance of payments is the difference between exports (X) and imports (M), but it is also (almost equally) the difference between savings (S) and investment (I). This second interpretation is often neglected, even though it is well known that this interpretation means that the balance of payments is a dynamic concept, describing the process of capital accumulation. Or to put it another way, this concept is forward-looking, implying that the current account is a result of intertemporal choice.

This insight, however, is often neglected in many IMF operations. Indeed, ESAF documents seldom refer to intertemporal substitution, even though intertemporal choice is discussed in the IMF's own Research Department. The IMF's Policy Development and Review Department, not long ago, conducted its own internal review of ESAF. The term "intertemporal choice," however, was not mentioned even once. Intertemporal choice was, of course, taken into account implicitly in the discussion of saving-investment behavior, but it was hardly treated explicitly to such an extent that the dynamic behavior of a nation was properly analyzed.

You might ask how can the actual ESAF operation reflect the intertemporal framework? Let us return to the S-I balance. In Asia, both savings and investment had been high for the past few decades, of course, until the recent financial crisis. In fact, investment was extremely high during the real estate boom. But investors and lenders both made mistakes, generating extraordinary invest- 
ment that was reckless. This left a heavy burden of debt and created opportunities for speculative attacks in Asia.

In Africa, by contrast, investment is low-whereas savings are extremely low. Here again, the current account is in deficit. In other words, in both Asia and Africa, nations are striving to live beyond their means. In both regions, international debt is growing. The difference is that in Asia, high investment generated economic growth, which was vital, as only with an increase in longterm growth could countries afford to pay off the debt. High investment countries - that is, assuming the investment is productive-have reason to hope that the investment will promote growth, but low investment countries have poor growth prospects. This is the problem for Africa.

\section{Problem of Intermediation}

Second, my comments concern the intermediation process between savings and investment. Financial intermediation functions need to be improved at every stage of the intermediation process. For example, in Malawi, when inflation was down to a single-digit figure, the discount rate was 23 percent. Admittedly, there were all sorts of information costs, transaction costs, and agency costs- the latter refers to the cost generated between the principal and the agent because they neither share the identical information nor identical motivation. I wonder, however, if a real interest rate of around 15 percent was a healthy rate at which investment for growth could take place.

In fact, the functioning of financial intermediation may easily be left in a vacuum without proper attention. Intermediation by the informal sector can be promoted-and indeed is promoted-by institutions like Grameen Bank in Bangladesh, and many nonprofit organizations. And the IMF monitors the central bank and large commercial or industrial banks. But in between, there are many other financial institutions, and the intermediation that they carry out is left unmonitored.

\section{Problem of Political Economy}

Third, I would like to comment on the political economy aspect of IMF operations. Recipient countries believe that they should recover-that is, take back-governance of economic policy from in- 
ternational organizations. IMF staff members, however, worry that if this happens, discipline will be lost. "There is a trade-off," they even say. But in my mind, the recovery of governance, in general, should mean the attainment of discipline as well. More autonomy should not mean a lack of discipline. Let me explain.

In general, when two countries or a government and an international institution negotiate on economic matters, this will take place as a two-level game. The lower level is the game of domestic politics, and the upper level is that of international negotiation. In other words, an international negotiation is superimposed on the domestic economic conflicts-which may include conflicts between various (particularly unsuccessful) pressure groups, often featuring the government bureaucracy as one of the pressure groups. Indeed, we saw this two-level game in Indonesia, when former President Suharto refused to liquidate his family businesses.

So when the IMF (or another international institution) advises local governments, the entry of the IMF changes the delicate balance between internal groups. But I have heard from many policymakers that their objectives are helped by outside pressures from the Bretton Woods organizations-a phenomenon that we call gaiatsu in Japanese. Some policymakers benefit from pressure by the IMF, and the IMF occasionally takes advantage of this effect. Indeed, resistance by certain domestic participants can be mitigated by the outside intervention. Thus, rather than emphasizing the recovery of governance from the IMF, I would take this multilevel game view and emphasize that conditionality and other tough medicine may work as an appropriate precondition for improved economic policymaking. If the interventions are too strong, however, then the negotiation itself might break up, and domestic politics might be upset by political upheaval. For this reason, political reform is also necessary, but difficult to realize-much like putting a bell on the cat. In Aesop's Fables, mice wanted to put a bell on the cat, but they do not know how.

A related problem is how we can introduce a good motivation mechanism into the system and the IMF in particular. According to the framework of the liberal political economy that is based on rational choice, the IMF could be formulated as an entity that is selfmotivated, and not necessarily motivated for the overall benefit of the world. Thus, an important question to ask is how can we design an incentive system that serves both the goodwill (and not too selfish intentions) of its Executive Board members and donors without overstretching the IMF's bureaucratic instincts? 


\section{How Costly is ESAF?}

\section{Table 1. Cost Estimates for Five ESAF-Supported Countries} (In millions of U.S. dollars)

\begin{tabular}{lccccc}
\hline Country & $\begin{array}{c}\text { Peak } \\
\text { Year }\end{array}$ & $\begin{array}{c}\text { Financial } \\
\text { Cost }^{1}\end{array}$ & $\begin{array}{c}\text { Administrative } \\
\text { Cost }^{2}\end{array}$ & $\begin{array}{r}\text { Total } \\
\text { Cost }\end{array}$ & $\begin{array}{r}\text { Total Cost } \\
\text { Relative to } \\
\text { GDP }^{3}(\%)\end{array}$ \\
\hline Bangladesh & 1991 & 101.6 & 1.7 & 103.3 & 0.44 \\
Côte d'Ivoire & 1994 & 66.1 & 1.7 & 67.8 & 0.91 \\
Malawi & 1990 & 10.1 & 1.7 & 11.8 & 0.63 \\
Uganda & 1994 & 40.2 & 1.7 & 41.9 & 0.80 \\
Zimbabwe & 1992 & 28.6 & 1.7 & 30.3 & 0.55 \\
\hline
\end{tabular}

Source: Based on information provided by IMF staff.

${ }^{1}$ Financial Cost = ESAF disbursement amount x 38\% (estimated grant element for ESAF).

${ }^{2}$ Administrative Cost $=$ average cost per year per country.

${ }^{3} \mathrm{GNP}$ data used for Bangladesh and Malawi.

Finally, a look at the relative costs and benefits of ESAF operations might help. I tried to estimate in Table 1 the total cost of ESAF for five ESAF-supported countries (four in Africa, one in Asia). The cost figure is made up of two components: the financial cost of concessional loans, which was about 38 percent of the loans made; and the average administrative cost, which the IMF estimates was about $\$ 1.7$ million in 1996. Using this administrative cost of 1996 (somewhat overestimated for the earlier years) and the peak year of ESAF operations in a given country, I found that the total cost ranged from $\$ 11.8$ million for Malawi to $\$ 103.3$ million for Bangladesh, and the costs relative to GDP ranged from an average .44 percent in Bangladesh to .91 percent in Côte d'Ivoire. (If we take the full ESAF period for these countries-not just the peak year-then the percentages will be one-third to one-half of the figure in the table).

How about the benefits side? This is much harder to estimate, but even so, one can infer the necessary amount of the benefits as a ratio to the GDP for the ESAF to economically break even. Thus, if one year of economic growth in Bangladesh was facilitated by more than a .44 percent increase relative to GDP because of ESAF, the cost-benefit ratio would be more than unity and clearly favorable. We tried to do this calculation with the ESAF-supported programs, but in the end, we did not publish these results with tentative estimates of benefits as part of our evaluation, ${ }^{1}$ partly because ESAF's benefit is ambiguous

\footnotetext{
${ }^{1}$ International Monetary Fund, External Evaluation of the ESAF: Report by a Group of Independent Experts (Washington, 1998).
} 
and partly because growth accounting can be tricky - that is, the outcome depends on how long one assumes the duration of the effect of ESAF to be. ${ }^{2}$

Incidently, I hear PDR staff claim that they do not engage in counter-factual experiments, although sometimes they do use graphs to show that ESAF helped real economic growth compared with the case without the program. ${ }^{3}$

My impression is that the comparison of this cost figure at the peak year with the growth performance of the succeeding year would give an unfavorable evaluation of ESAF. By contrast, the comparison of the average cost figure for all the ESAF years with the accumulated growth performance of the subsequent few years would give a much more favorable evaluation of it.

Another important message from the table is that these cost figures are relatively modest, ranging at most to several hundred million dollars. I would like to stress the contrast of these modest figures to the very large amount of funds that the IMF and cooperating countries have been extending to the Asian crisis countries. Comparatively as well as absolutely, Africa is entitled to attract more care and attention.

\section{Jesus Estanislao}

Being from Asia, I must start my comments with an apology. I apologize to everybody because we have created a crisis in Asia and are not setting a very good example for Africa. And since I come from the Philippines, I must double up my apology because in the mid-1980s the Philippines was in crisis, and in the mid-1990s we are once again sharing the crisis with our Southeast Asian neighbors. Having established my Asian credentials by providing multiple apologies at the start of my intervention, I would now like to get to the main points.

\footnotetext{
2In general, if the effect of the ESAF is taken to continue for a single year, the ratios can become unfavorable, except for Bangladesh. But if the benefit of the ESAF is taken to continue for more than a year, the benefit of the ESAF will exceed the cost.

3See International Monetary Fund, The ESAF at Ten Years, IMF Occasional Paper No. 156 (Washington, 1997), p. 25. The internal review of the ESAF program gives some suggestive evidence (Figure 16, "Explaining Increases in Growth Since the Early 1980s") for the role of the ESAF in growth. If the total increase is attributable to the program, there is no room for dispute. However, if only a part of the improvement is attributable to the ESAF, the cost-benefit ratio cannot be definitively evaluated. Note that for Africa, even the total benefit is limited.
} 
In reflecting upon the financial crisis that has affected Southeast Asia and Korea, and on the debt crisis of the past 10-15 years, the first point that comes up is the absolute importance of macroeconomic fundamentals. Of these, there are at least three: a strong fiscal position, low inflation, and flexible exchange rates.

The first two have been strongly emphasized by the IMF. Indeed, the IMF has been very doctrinaire about making sure that our fiscal position is strong. In other words, get fiscal deficit ratios down or, if possible, go into a surplus. An essential part of the doctrine has been that a strong fiscal position assures low inflation rates.

But the Asian crisis has shown that the third macroeconomic fundamental is as crucial as the first two. It may not have been given enough emphasis in the past. However, in a world that is globalized, where economies are more open and interdependent, it is crucial to keep exchange rates realistic. A base for some of the problems South East Asia faced this past year has been the disregard for China's depreciation of the yuan in 1994 and for Japan's gradual depreciation of the Japanese yen since 1995. Most South East Asian economies insisted on pegging their exchange rates to a single anchor, the U. S. dollar. Unfortunately, the dollar kept on strengthening, and this created a lot of problems and brought in a lot of pressures.

So lesson number one from the Asian crisis is the continuing importance of low fiscal deficits and low inflation. These two macroeconomic fundamentals are absolutely necessary. However, they may not be sufficient. The Asian crisis also highlights that we cannot disregard the importance of keeping exchange rates realistic.

A second point is the imperative for keeping banking systems strong. A crisis is not likely to occur where the banking system remains very strong. On the contrary, where the banking system is weakened through various types of practices-such as crony capitalism, unrealistic exchange rates, and lack of transparency-there a crisis looms. Shake that structure a bit by an exogenous macroeconomic event or by some shock to the system, and it can unravel fast. Before anyone can bat an eyelash, the banking system or the financial system can get into a very serious crisis. And this can be a very expensive proposition.

In the Philippines in the mid-1980s, we spent probably 15 percent of GDP trying to clean up our banking system. Fortunately, as we go into this crisis now, our banking system is much stronger, but I suspect that the Thai crisis and the Indonesian crisis may be equally 
expensive, if not more, simply because they have allowed their banking system to weaken over many years.

So the second lesson from the current crisis is that banking and finance being at the very core of the economy must be taken care of very prudently. Take good care of them and you will take care of the guts of the economy.

But for banking and finance to be well taken care of, you need to make sure that the central bank has enough autonomy. It should not be subjected to political pressure, or you will end up with the crony capitalism evident in East Asia today. And you will end up with a very expensive bill that any minister of finance will cringe at paying, simply because it drags the system down for a very long time.

The central bank, as the depository of the Holy Grail of any economy, has to be treated with respect and reverence. You cannot afford to bankrupt it or to prostitute it. Therefore, you have got to take very good care of it, because in the final analysis, what is absolutely necessary is the confidence that the local population and the international community have in the local banking system.

The third lesson is the need to strike precisely in a period of crisis. It is the time to move forward with reforms. Do not succumb to the danger of thinking that in a period of crisis you have to slow down and step back from reform. In our experience in the Philippines, crisis is an opportunity one has to take advantage of to introduce reforms. Trade liberalization, privatization, institution building, and other reforms can and should be speeded up at a time of crisis. It is a window of opportunity that may not remain open for a long time. The Deputy Prime Minister of Thailand recently stated that ASEAN, in the midst of the crisis in December of 1997, decided to move ahead with trade liberalization rather than step back. This is one lesson we can share with you.

Finally, even as we stress strong macroeconomic fundamentals, strong banking systems, and a strong commitment to reforms, we should also keep a broad perspective. Yes, there is a need for savings, but also for appropriate investments. Of even greater importance is the need for prudence and measure in everything.

In East Asia today, the problem is not overconsumption. It is overinvestment. It is not the lack of private sector initiative. It is greed and imprudence of the private sector. The debt problem of East Asia today is not public sector debt. It is private sector debt. The problem is not from opening up, but from the lack of prudential norms in strong institutions that must be in place as economies open up. 
The problem is not from overregulation, but from a relative lack of prudential regulations. Without proper controls in place, we can have a problem not only with our current account but also with our capital account. That is what we are faced with today.

In sum, all the macroeconomic fundamentals are absolutely necessary. But beyond the fundamentals, beyond reforms, there is also a need for building up civil society - that is what we are finding in Indonesia today - and for promoting the value of citizenship and the spirit of civic responsibility. While we take care of economics and finance, we cannot disregard the politics, the social aspects, and indeed the broader aspects of society.

We cannot set aside the requirements of good politics, as we concentrate on meeting the demands of good economics and finance. These have to go together-the political reforms with the economic reforms - they need to be put in place as quickly as possible.

\section{Anupam Basu}

In considering how growth in Africa can best be achieved, the challenge for policy makers is to identify the key reform priorities. This involves adopting a global approach and designing an economic policy framework that envisages growth to be export led and based on the development of the private sector. To achieve that kind of growth on the ground, market-based economic policies would have to play a critical role.

How do you implement these policies successfully and in an orderly fashion? In order to ensure orderly and sustainable growth, it is extremely important to put in place a proper regulatory environment and also, as Jesus Estanislao mentioned, sound macroeconomic policies.

Moreover, for the reform effort to be credible and successful, one would need to move forward simultaneously in several of the key reform areas because of their complementarity and mutually reinforcing nature. The reform areas discussed in this seminar-namely, regulatory reform, financial sector reforms, the strengthening of the role of government, especially in the areas of public expenditure management and social development, and trade liberalization-are complementary. Progress in any one area will enhance the gains made in the other areas. Therefore, in my mind, the issue really is, What is the set of reform priorities? And not, What is the hierarchy among them? 
Viewed from this perspective, the task of identifying reform priorities in Africa can be distinguished clearly from that of their sequencing, which is one of the qualities or properties of an efficient reform process. Once a set of priorities has been established in the reform process, its quality and efficiency will depend on four properties: whether or not it is properly sequenced; whether it has been developed with the participation of, and in consultation with, the private sector; whether it reflects ownership by government and civil society; and whether its goals are transparent and implementation predictable.

\section{Set of Reform Priorities}

Let me now turn to four questions related to the selection of specific reform priorities.

First, why do we need regulatory reforms? The reason is that an appropriate regulatory framework promotes the smooth and proper functioning of markets. It is complementary to the other reformssuch as trade and financial sector liberalization - that are required to establish a market-oriented economic environment. To foster such an environment, regulations must have the desirable properties of transparency and predictability. They have to be evenhanded and provide a level playing field for all economic agents, that is, they should not be applied in a discretionary and arbitrary manner but uniformly in practice. And they should require accountability.

One area where a proper environment of prudential regulation and supervision is essential is financial intermediation. The establishment of accounting standards and the publication of audited accounts by enterprises are critically important for the growth of sound bank lending practices. The development of an appropriate legal framework, including laws relating to foreclosure procedures, property rights, transfer of land titles, bankruptcy procedures, and contract enforcement, is also fundamental to the growth of the private sector and financial intermediation. Indeed, it is the lack of progress in these legal and regulatory areas that explains two concerns expressed by earlier speakers-namely, that bank credit to the private sector has remained inadequate in Africa; and that investment rates have responded only weakly to financial sector reforms.

Second, why should financial sector reforms be given a high priority? The answer lies in recognizing the vital role of banks in any 
economy. Banks in Africa, as elsewhere, select projects and activities to finance. In the process, they make it possible for large projects to benefit from a pooling of resources from small savers, and they also pool the risks in various projects by financing a mix of projects. In making loans, banks need to take into account intertemporal considerations, such as the future repayment capacity of their customers. All of these are ambitious-but necessary-tasks for banks in Africa to perform.

The banking system will be able to perform these functions more efficiently if reforms are implemented to restructure and privatize weak state-owned banks; ensure adequate prudential regulation and supervision of banks; promote the entry of adequately capitalized new banks; eliminate direct credit controls; develop bill markets and liberalize interest rates; and establish efficient payments systems.

One indication of the importance of banking institutions is the function of bank lending as an intermediate input for most productive activities, including investment. Unless the banking system intermediates efficiently, providing an input for either investment or production activities would be very costly. It is, therefore, important to undertake the reforms needed to ensure the efficient functioning of the financial markets. There is ample evidence in Africa that markets in the financial sector do function well once they are reformed. One can see the evidence in treasury bill markets and in the exchange markets (under the flexible exchange rate systems).

Financial sector reforms must also address the problem of missing markets. For example, however much one may try, urban banks will most likely not provide microfinance. They will not reach out to the small farmers in the distant farms, because of the high cost of doing so. The same shortcoming sometimes applies to long-term finance activities. In these situations, the government does have a role to play, and the issue is, what is the most efficient institutional framework to address such problems?

Third, why should rethinking the role of government be given a top priority? Governments will need to continue to play an important role in African economies for several reasons. There are some things that cannot be left to the markets. Formation of human capital cannot be bank financed or financed by private markets, because neither banks nor the private sector will find the collateral for it, nor will they look at the expected future earnings from such investment. The spillover benefits (or positive externalities) to the economy of gov- 
ernment efforts to promote basic education, health, roads, law and order, and sound macroeconomic policies are well recognized; therefore, these tasks should be in the hands of government. Even in the area of technology development, where the risks associated with uncertain earnings prospects are high, the positive externalities are potentially large. In this context, I agree with Kwesi Botchwey that the importance of tertiary education cannot be neglected; of course, the other strong vehicle is foreign direct investment.

As the role of government will remain important, a key issue is, how can the government be made to function better or more efficiently? The answer lies in improving the quality of institutions in economic management and other complementary areas, and in establishing appropriate rules and safeguards. An independent judiciary, institutional checks and balances, and an effective office of the auditor general are some of the necessary ingredients of a strategy of institutional development. Effective civil service reform is also vital, so that the government is better equipped to implement the reforms and deliver the essential public services.

Fourth, why should trade liberalization take on so much importance? Given the need for integration into the global economy, the rationale for liberalizing foreign trade is well understood, and the debate in this area is generally focused on how best to achieve it. One approach that is gaining ground is to preannounce a timetable of trade reforms in the context of adjustment efforts and regional integration initiatives, and to adhere to it. This approach would allow firms the time to adjust their production and related activities so as to function more competitively over time.

As regards liberalizing trade through regional integration, it is important to note that the costs of moving in this direction are sometimes exaggerated. If there is little regional trade in Africa, as some speakers have argued, then there can be little risk of loss of fiscal revenues from regional trade liberalization; also, there is likely to be little employment loss associated with it. That, of course, is an assessment of the static costs of such initiatives. One must also consider the positive dynamic benefits from free cross-border trade in a region. It would inject a greater measure of competition among established import substitution firms in the region. Also, regional trade liberalization, combined with the harmonization of the national regulatory environments, the tax systems, and the investment codes, would provide investors with larger markets and more level playing fields for their production and investment activities. Regional initiatives offer 
opportunities for infrastructure cooperation and development, for financial sector integration, and, most important, for progress toward multilateral liberalization. The latter opportunity is all the more important, particularly in areas of zero or low regional trade, where trade liberalization basically entails multilateral liberalization.

Lastly, an issue that deserves more attention is the costs of granting special trade and other tax incentives to foreign private investors. Proponents of such incentives need to weigh the costs of discriminating against domestic investors. Moreover, one must also consider the justification for relying on tax incentives. Given that, in most African countries, the thrust of structural tax reforms is to move from trade taxes to domestic taxes and to simplify and rationalize the tax structure, there would appear to be little justification for introducing a discriminatory structure of trade and other taxes and giving tax concessions. Such actions weaken the domestic tax base, which is supposed to make up for the loss associated with trade tax reforms.

In sum, achieving the objectives of rapid economic growth and substantial poverty reduction in Africa will require the implementation of market-oriented policies aimed at both promoting the development of the private sector and accelerating Africa's integration into the global economy. Such a growth strategy will need to be underpinned by an integrated and mutually reinforcing set of macroeconomic polices and structural reforms. These should foster economic liberalization through reforms of the legal and regulatory environment; the financial sector; the foreign investment, trade, and exchange regulations; and the role of government-including by improving tax systems to make them nondistortionary and nondiscriminatory, and restructuring public expenditure to give priority to the social sectors.

Finally, the benefits of such a reform strategy could be substantially enhanced by regional initiatives. These should aim at promoting macroeconomic stability; the harmonization of regulatory systems; cross-border trade, investment, and financial flows; infrastructure cooperation; and progress toward opening up the region to the global economy.

\section{Micah Cheserem}

While this seminar is on the challenges of globalization in Africa, I would like to focus mainly on those issues that I believe need to 
be given priority if Africa is to achieve sustainable economic growth. These include the need to educate all stakeholders in the reform process, and the need to more aggressively implement both political and economic reforms.

\section{Educating the Stakeholders}

Historically, information on Africa has been available to only a few selected individuals, mainly the elite and those who controlled the organs of government. This could be information on a wide range of issues-particularly political, social, and economic. I believe the objective of withholding this information was to ensure that the few who dominated key sectors in the public and private domains-whether they were academicians, politicians, or the elite-continued to benefit from their privileged positions at the exclusion of the majority.

But the implementation of economic reform affects all, be they the elite who control information, or the ordinary individuals who have to bear the greater brunt of the sacrifice in the short term so that the long-term benefits of reforms can be realized. Thus, for reforms to be successful, it is vital that informed debates and discussions be expanded to a broader society, so that the benefits are fully understood and ownership of the reforms is accepted by all stakeholders.

African countries, in collaboration with the IMF and the World Bank, should embark on a massive education of all stakeholders to explain the rationale behind the implementation of the various economic reforms. The media fraternity can play an important part in this process. But to do this successfully, it should be among the first to be educated. Otherwise, the media can easily become a bottleneck to the economic reform effort.

Kenya has recently implemented a series of economic and financial reforms aimed at creating and maintaining a vibrant market-driven economy. Initially, there was resistance to the reforms as they were considered to be policies of the IMF, forcefully imposed upon Kenya. But gradually, the government, by forging a partnership with the private sector and other stakeholders, has encouraged a broader participation in the dialogue. We have done this by organizing various fora where the economic policy issues are discussed candidly. In addition, official publications by governmental institutions have been instrumental in explaining to the general public the various economic initiatives. 


\section{Political Reforms}

For economic reforms to be successful, they must be accompanied by political reforms, which include a multiparty democracy, good governance, a free media, and respect for human rights. Despite a long record of involvement in Africa's development efforts, the IMF has tended to ignore the importance of political reforms in ensuring that the economic reforms are sustained. The IMF continues to emphasize the need for macroeconomic stability and related structural reforms. But this inevitably leads to only partial success of the reform efforts, as corruption and lack of accountability in the management of resources continue to result in inefficiency and misuse of public funds. It is thus opportune for the IMF to become actively involved in political reforms to complement the successful implementation of economic reforms. In recognition of the importance of political reforms, the majority of African countries are currently deepening the democratic process, thereby encouraging quality leadership.

\section{Economic Reforms}

Until the 1990s, economic management in Africa was characterized by government domination of production, trade, prices, and all areas of economic activity. These inappropriate economic policies and programs led to overexpansion of the public sector, erosion of incentives of industry and agriculture, and overprotection of industry.

A number of African countries-including Kenya-have begun implementing economic reform programs to reverse the socioeconomic decline that has beset the continent since the 1970s. To fully integrate itself into the world economy, Africa should continue with the reform process by doing the following:

Speeding up removal of remaining economic controls. Africa has fairly well succeeded in liberalizing domestic prices and the trade system, thereby giving a free hand to the market mechanism in allocating resources. There is, however, a need to speed up the trade liberalization process and eliminate all nontariff barriers to trade. The tariff system should also be streamlined by further reducing import and export duties and tariff bands. This will enhance the efficiency of domestic industries 
and increase their competitiveness in the international market place.

Accelerating the privatization of state enterprises. Privatization was initiated to reduce the government's presence in economic activity and increase the scope for private-sector-led sustainable growth. Substantial progress has been made in privatizing smalland medium-sized enterprises, but progress has been very slow in privatizing large, and what the government considers to be, strategic enterprises.

Implementing civil service reforms. Many African countries have undertaken civil service reforms with the aim of creating a lean and efficient public service. This has included steps to downsize the civil service, mainly by cutting costs through a reduction of the wage bill. Reforms should continue if governments hope to boost the morale of those remaining in the civil service. This can be done by restructuring remunerations in line with those in the private sector.

Encouraging formation of regional trading blocs. Recently, there have been initiatives towards regional economic integration in Africa so that individual African countries can benefit fully from increased intra-African trade. While earlier efforts were constrained by the duplication of regional programs, Africa is now determined to develop more efficient and comprehensive programs and projects on regional economic cooperation.

Undertaking concerted efforts to fight corruption. In many countries, corruption continues to be a threat to the efficient delivery of services both in the public and private sectors. The major challenge for African governments is to design systems that remove opportunities for individuals to engage in and benefit from corrupt activities.

Increasing the autonomy of central banks. In recent years, there has been a greater interest in enhancing the independence of African central banks in the formulation of monetary policy. This is consistent with the global trend and argument that for a central bank to achieve and maintain price and financial stability, its policymaking machinery should be free of government influence. 


\section{Conclusion}

Africa has learned over the past four decades that the heavy hand of government retards growth, and as a result, the continent-for many years now-has been pursuing both political and economic reforms. These are aimed at encouraging broader participation in public policy issues and facilitating the role of the private sector in economic growth. Africa's economic prospects have never been brighter, as both domestic and foreign investors take advantage of the positive developments in political and economic conditions. 


\section{General Discussion}

\section{Priorities for Reform}

Edith Gasana of Rwanda opened the discussion by putting forward the case of countries recovering from disasters or other special difficulties; countries whose entire economic system had been destroyed. For them, designing, approving, and implementing a budget - a complex process in its own right—posed enormous hurdles. "We know about priorities. But we need the resources to be able to draw up programs and have some cash, and in our case, cash can only come from the outside." Yet, defining our priorities, already quite difficult to do, was made even more complicated by the fact that donors' priorities tended to prevail.

Mansour Cama of Senegal gave a private sector view, suggesting two priorities for African governments. First, governments needed to carry out public relations exercises to ensure that citizens understood the budget. This would help citizens to participate in the budget debate and assume responsibility for monitoring outcomes. Indeed, budgets needed to be drawn up more in line with a form of government that was in the service of its citizens. Second, governments should do more to promote the image of their countries-not leaving the task to donors. The world needed to know that African countries had undertaken reforms and that they were working.

As for priorities for the private sector, Cama remarked that in the end, everything was a priority because of all the interlinkages. Even so, he singled out the need for a better partnership between the government and the private sector; the need for foreign investors to see that local enterprises were successful, that there were profits to be made; and the need for better vocational training, if countries really hoped to tackle competition and productivity.

Michel Reveyrand of France supported the calls for better communication, noting that not enough was being done in Africa to spread the word about success stories. Moreover, there was a lot to 
be gained from an exchange of views and experiences between partners in the public and private sectors, and even within these sectors. Public sectors needed to be modernized, an area where donors could help. And private sectors needed to absorb the values of private entrepreneurship, an area where African governments could help.

Hak KukJoh of Korea wanted to go on record as supporting the basic policy framework being discussed for adjusting to the challenges of globalization - trade liberalization, deregulation, financial sector reform, privatization, and good governance. This framework was based on the belief that the market worked and did pay off. But he underscored that for the market to work properly, there needed to be many active and potential competitors, both in the input and output markets. Otherwise, the market would easily become more monopolistic. At present, African countries suffered from limited human resources, social infrastructure, savings, and investment. International development agencies could help by focusing on these areas.

Christophe Marchand of France stressed the need for improving the quality of expenditures, as opposed to focusing on their size. What could be done to improve the quality? Here he felt regional integration and neighbors adopting common policies-such as in trade, monetary policy, and foreign exchange-could play an important role by achieving economies of scale and limiting negative spillover effects. 


\title{
Concluding Remarks
}

\author{
Evangelos Calamitsis
}

\section{$\mathrm{T}$} his has been a most useful seminar, the fourth in a series initiated in 1994, and I would like to thank all those who contributed to its success. In particular, I would like to express our appreciation to the Ministry of Finance of Japan for sponsoring this seminar, and for its continued encouragement and support in such events. I would also like to express our gratitude to all of you for participating over the past day and a half in a frank and fruitful exchange of views on how we can best help Africa in meeting the challenges of economic globalization and integrated financial markets.

We have had this discussion at a time when Africa's economic performance and outlook have been improving. After some two decades of lost opportunities, real GDP is now growing on average at 4-5 percent, and per capita incomes are on the rise. Most important, although favorable external circumstances and weather conditions have helped in some cases, this progress has been due primarily to good economic policies_-getting prices right, reducing internal and external imbalances, liberalizing exchange and trade systems, and proceeding with fundamental structural reforms.

Yet, Africa's growth still lags behind that of many developing countries, and questions have been raised about whether recent economic gains are sustainable. This is particularly troubling, since Africa needs even faster growth to make up for the ground lost and to make a real dent in the pervasive poverty. While several 
factors are holding back a better growth performance, two stand out. First, the private sector response is still very cautious, as evidenced by the inadequate rates of private saving and investment, including foreign direct investment. Second, Africa has been relatively slow in integrating itself into the global marketplace. Thus, Africa has been missing out on the benefits of globalization that accrue to countries that open themselves to world markets, as well as risking the marginalization that faces those countries that fail to do so.

A basic question before us, therefore, was how to sustain and even accelerate Africa's growth in a globalized world. There is little doubt that the answer lies in creating an environment that promotes better government and fosters private entrepreneurship. In this regard, a number of participants remarked that many African countries have already been doing a lot to promote this process through adjustment and reform measures. But as Kwesi Botchwey put it so well, the issue is how to establish reform priorities in the midst of limited capacities. Listening to the discussions and the panel on the reform priorities for Africa, I believe that several building blocks were highlighted-which are increasingly being referred to as the "second generation of reforms." Apart from consolidating macroeconomic stability, which is essential, these include:

- establishing a clear and equitable regulatory framework;

- strengthening the financial sector and improving financial intermediation;

- further liberalizing exchange and trade systems;

- enhancing capacity to formulate and implement national reform programs; and

- improving public resource management and delivery systems in support of basic social services.

An underlying theme, of course, was how to draw on the wellknown success stories of Asia, as well as on the lessons of the recent crisis, to help Africa improve its growth and efficiency, and thus be competitive on world markets. Naturally, the precise list of priorities differed among participants, but with capacity building high on the list of virtually all. Allow me to comment briefly on the main issues. 


\section{Improving the Business Environment}

All participants agreed that a business-friendly and predictable regulatory environment is needed to attract both domestic and foreign investment-especially much needed foreign direct investment. The regulatory framework should safeguard property and related rights through well-defined legislation; it should be transparent and easily enforceable, as well as free of any taint of arbitrariness or favoritism.

But the mere existence of a good legal framework is not enough. As Florian Alburo and others noted, the rules must be applied equally, impartially, and without exception. This underscores the need for an independent and efficient judiciary. In other words, regulatory reform must be supported by institutional reform.

\section{Strengthening the Financial Sector}

As to the financial sector, the message was clear. A sound financial sector is essential for fostering private saving and investment, and attracting private capital in a globalized world. This messagealong with the need for full transparency and accountability-has been driven home most recently by events in Asia.

Despite some recent progress, however, Africa needs to accelerate reform in this area. What needs to be done was set out in Piero Ugolini's presentation and Leonard Tsumba's paper. The critical elements include an independent and accountable central bank with autonomy in the conduct of monetary policy to maintain price stability; a sound banking structure; an appropriate banking supervision framework, based on best international standards; and a well-functioning payments system.

A particularly important challenge for Africa is to foster competition among banks and to deepen financial intermediation with a view to channeling more effectively financial resources to the private sector. To this end, fiscal discipline is critical to reducing the crowding-out effect of government borrowing from the banking system.

In this process of strengthening the financial sector, the building of a class of qualified national financial managers, regulators, and supervisors-not to mention ensuring their independence from political interference-is indispensable. This will take time, but the 
task should not be delayed. It should be supported by well coordinated technical assistance and training from the Fund, the World Bank, and other institutions.

\section{Further Liberalizing Trade Regimes}

As for trade reform, there was broad agreement that Africa needs to step up the liberalization of its trade regime if it is to reverse a declining share of world trade and lay the foundation for higher growth of output and exports. Certainly, the experience of Asiaand more recently Latin America-shows clearly that an outwardoriented trade strategy delivers notable results in terms of efficiency, competitiveness, and superior growth performance. Moreover, trade liberalization and related improvements in the transparency of the trade regime are essential to enhancing the investment climate. Although much progress has been made in recent years, as Robert Sharer and others noted, Africa was starting from a highly restrictive position, and hence today most African trade regimes remain significantly more restrictive than those of other developing regions. Therefore, as participants agreed, the issue is not whether trade regimes should be liberalized, but rather how fast and how deeply.

Some African participants worried about the ability of their countries to compete effectively in international markets. In this connection, as elsewhere, capacity building was deemed essential, as highlighted by Tomás Salomão and Ibrahima Makanguilé. A number of speakers noted that social safety nets and fiscal concerns about possible revenue losses from trade taxes need to be factored into the design and timing of trade reform programs. However, it was recognized that the time frame for reducing tariff and nontariff barriers needs to be credibly ambitious to have the desired impact. Many speakers emphasized the importance of regional arrangements in the process of trade liberalization. Such arrangements also play a useful role in harmonizing improvements in the regulatory and fiscal areas.

Several participants considered that other factors tended to prevent trade liberalization from boosting capital inflows. It was noted that time lags between the implementation of the right policy framework and the response of foreign direct investment seem to be unduly long in Africa. This suggested that, although Africa is now on the mend, it is still paying the price of its poor image. 


\section{Fostering Good Governance and Capacity Building}

So the message coming through in all these areas-regulatory, financial, and trade reform-is that policies have to be consistent, credible, predictable, and transparent. In the language of today, what is needed is good governance. That, in turn, underscores the need for modern administrations with competent, motivated civil servants who will be able to deal with strong vested interests.

What can governments do to ensure that there is the needed human capital and institutional structures to carry out the required reforms? We all agreed on the critical importance of civil service reform, but the record to date in this area has not been impressive. Many of you spoke of the problems you encountered in your countries when you attempted to downsize the civil service and reduce the wage bill. Perhaps one solution lies in removing a number of government functions from the core civil service. Certainly, more thought needs to be given to the size and functions of the civil service in the context of the new and more limited role of government.

Of course, technical assistance should have been playing a key part in building up Africa's capacity. But many of you noted that, despite the very large sums spent, technical assistance has not produced the desired results. It is still too supply-side driven and uncoordinated; and foreign experts often continue to do the job of nationals, leaving few trained local staff in their wake. How long do we have to keep going over the same ground? In my mind, one hopeful development is the capacity-building initiative recently developed by Africans themselves, which focuses on the definition of needs at the national level and the mobilization of external assistance to support these needs in a coherent and coordinated manner.

\section{Improving Public Resource Management}

Are there any steps governments can take to accelerate the formation of human and physical capital, using the limited resources that they have at their disposal? And what is their record on the use of these resources to date? A recent IMF study of 22 countries in Africa shows that there has been some progress since 1985 in allocating more resources for education, health, and basic infrastructure in relation to GDP-and these higher outlays have been accompanied by improvements in some social indicators. The share of social 
spending in the total also rose, suggesting that such spending has become a higher priority. Spending on basic infrastructure, notably on transport and communications, has also increased. But greater attention needs to be paid to the composition and efficiency of public expenditure, especially with a view to ensuring that the poor are those who benefit the most.

\section{Concluding Thoughts}

In closing, I wish to make two points.

First, I think we all agree that, even though Africa's development partners have a vital role to play in supporting reform programs, efforts to develop effective institutions and regulations-and to remove any remaining official tolerance for corruption-must be home-grown. Such efforts cannot and should not be imposed from outside. This is consistent with one of the central findings of the IMF's recent external ESAF evaluation.

Second, where there is successful reform, the countries and donors alike need to do a better job of conveying this message to foreign investors. In other words, we must help bridge the "image gap" between the old and the emerging Africa. 


\section{List of Participants}

\section{Chairmen}

Jack Boorman

Director

Policy Development and Review Department

International Monetary Fund

Evangelos Calamitsis

Director

African Department

International Monetary Fund

Motomichi Ikawa

Senior Deputy Director General

International Finance Bureau

Ministry of Finance

Japan

\section{Speakers}

Florian Alburo

Professor, School of Economics

University of the Philippines

Philippines

Luca Barbone

Sector Manager

Macroeconomics

Central Africa and Indian

Ocean

World Bank
Harris Mule

Chairman of TIMS Ltd.

and formerly

Permanent Secretary

of Finance

Kenya

Emmanuel Tumusiime Mutebile

Permanent Secretary of the Treasury

Ministry of Finance,

Planning and Economic

Development

Uganda

Robert Sharer

Chief, Trade Policy Division

Policy Development and

Review Department

International Monetary Fund

Leonard Tsumba

Governor

Reserve Bank of Zimbabwe

Zimbabwe

Piero Ugolini

Advisor

Monetary \& Exchange Affairs

Department

International Monetary Fund

Note: The affiliations and titles are those at the time of the seminar. Micah Cheserem, Harris Mule, Emmanuel Tumusiime Mutebile, and Leonard Tsumba were not present at the time of the seminar but submitted papers and comments. 


\section{Commentators}

Kwesi Botchwey

Visiting Scholar and

Development Advisor at the Harvard Institute for

International Development and formerly Minister of

Finance for Ghana

Ghana

Iain T. Christie

Lead Technical Specialist

Private Sector Finance Group

Africa Region

World Bank

James Cross

Deputy Governor

Reserve Bank of South Africa

South Africa

Vina-Seeburn Dabeesingh

Mauritius Securities Exchange Commission

Mauritius

Jan Willem Gunning

Professor

Centre for the Study of African Economics

Institute of Economics and

Statistics

University of Oxford

England

Sanjeev Gupta

Chief, Expenditure Policy

Division

Fiscal Affairs Department

International Monetary Fund

Takuma Hatano

Director-General

Loan Department I

The Export-Import Bank of Japan

Japan
Hiroyuki Hino

Professor of Economics

Research Institute for

Economics and Business

Administration

Kobe University

Japan

Hirohisa Kohama

Professor of Economics

Faculty of International

Relations

University of Shizuoka

Japan

Ibrahima Makanguilé

Secretary-General of the

Network of Private

Entrepreneurs in Mali

Mali

Gray Mgonja

Deputy Permanent Secretary

Ministry of Finance

Tanzania

Emmanuel Tumusiime Mutebile

Permanent Secretary of the

Treasury

Ministry of Finance,

Planning and Economic

Development

Uganda

John Roberts

Adviser

Macroeconomic Policy and Economic Reform Unit

E.C., Directorate General for Development (VIII)

Belgium

Reinold van Til

Assistant Director

Southern African Division III African Department

International Monetary Fund 


\section{Panelists}

Anupam Basu

Deputy Director

African Department

International Monetary Fund

Micah Cheserem

Governor

Central Bank of Kenya

Kenya

Jesus Estanislao

Dean

Asian Development Bank Institute

Asian Development Bank Philippines

Koichi Hamada

Professor

Economic Growth Center

Yale University

United States

Tomás Salomão

Minister of Planning and

Finance

Mozambique

\section{Participants}

Moses Asaga

Deputy Minister of Finance

Ministry of Finance

Ghana

Robert Beadle

Administrator

OECD

Joey Mozorodze Binha

Ambassador to France

Zimbabwe

Jean-Claude Brou

Directeur du Bureau du

Premier Ministre

Côte d'Tuoire
Mansour Cama

Chairman and CEO

Confederation Nationale des Employeurs du Senegal

Senegal

Jan Cedergren

Director General for

International Development

Cooperation

Ministry of Foreign Affairs, and Chairman of Reference Group for the Independent Evaluation of the Special Program of Assistance for Africa Sweden

Louis Dicks-Mireaux

Deputy Chief

Development Issues Division

Policy Development and

Review Department

International Monetary Fund

Peter Freeman

Director

Africa Division

Department for International

Development

United Kingdom

Edith Gasana

Secretary General of the

Ministry of Finance and

Economic Planning

Rwanda

Elliott Harris

Assistant to the Director

African Department

International Monetary Fund

Hitoshi Hirata

Representative

Overseas Economic

Cooperation Fund

Japan 
Takashi Ito

Representative

Overseas Economic

Cooperation Fund

Japan

Sara Johansson

Young Professional

OECD

Hak Kuk Joh

Director-General

Anti-Trust Bureau

Fair Trade Commission

Korea

Akihiko Koenuma

Deputy Director

3rd Division

Operations Department III

Overseas Economic

Cooperation Fund

Japan

Yoshihiro Kumagai

Representative in Paris

Exim Bank of Japan

France

Tomoko Kurata

Special Assistant

Overseas Economic Cooperation Fund

Japan

Takeshi Kurihara

First Secretary

Embassy of Japan in France

France

Martine Mabiala

Chargé d'etudes aupres du Conseiller

Financier du Ministre

Gabon

Christophe Marchand

Chef du Bureau F2
Afrique Zone France

Direction du Trésor

Ministere de l'Economie et des Finances

France

Antony Requin

Bureau F2

Afrique Zone France

Direction du Trésor

Ministere de l'Economie et des Finances

France

Jean Pesme

Bureau F2

Afrique Zone France

Direction du Trésor

Ministere de l'Economie et des Finances

France

René Mbappou

Secrétaire Permanent

du Comité de Suivi

des programmes

économiques

Ministére de l'Economie et des Finances

Cameroon

Kunio Okamura

Chief Representative

Overseas Economic

Cooperation Fund

Japan

Daniel Ramarokoto

Le President de Secretariat

Technique de l'Ajustement

Madagascar

Michel Reveyrand

Chef de Service

Coordination Géographique et Etude 
Secretariat d'Etat à la

Cooperation

France

Mitsunori Saito

Trainee, Overseas Economic Cooperation Fund

Japan

Kazushi Sato

Deputy Director

Development Policy Division

Ministry of Finance, Japan

Godfrey Simasiku

Deputy Minister of Finance and Economic

Development

Zambia

Takafumi Suzuki

Chief of Management

Development Policy Division

Ministry of Finance

Japan
Seiji Tate

Special Officer

Embassy of Japan in France

France

Hitoshi Tojima

Representative

Overseas Economic

Cooperation Fund

Japan

Koichiro Tsuchiya

Deputy Chief Representative in Paris

Exim Bank of Japan

France

Laura Wallace

Senior Public Affairs Officer

External Relations Department

International Monetary Fund

Yukio Yoshimura

Executive Director, Japan

International Monetary Fund 